$\mathrm{O} 1$

\section{小児気管支喘息児の呼吸音と重症度の関 係}

○土生川千珠 ${ }^{1)}$ 、村上佳津美 ${ }^{2)}$

竹村 司 ${ }^{2)}$ 、長坂行雄 ${ }^{3)}$

1)南和歌山医療センター 小児科

2)近畿大学医学部小児科

3) 近畿大学医学部堺病院呼吸器科

【はじめに】小児気管支喘息児の呼吸音解 析を行い、呼吸音と喘息重症度との関係に ついて検討した。

【対象】当院小児科に定期的に通院してい る気管支喘息患児のうち外来受診時に発作 が出ていない状態で呼吸音解析に協力が得 られた 72 名で, 年齢は 6 ケ月から 5 歳であっ た.

【方法】呼吸音解析システムSSAS - 2000 （Kenz medico）を使用し、右鎖骨中線上 第 2 肋間において呼吸音解析を行った。呼 吸音は, 最低 10 秒間測定し, 吸気, 呼気の 最高周波数, 強度, Peak Frequencyについ て検討した. また対象の喘息重症度分類を 行い呼吸音との関係について検討した。喘 息重症度の分類にはGINA2002 度版を使用 した。

【結果】呼吸音のうち, 非発作時吸気最高 周波数と, 喘息重症度の間に関連がみられ た. 非発作時呼気周波数とは関連が見られ なかった

【考察】非発作時呼吸音のうち吸気最高周 波数は，喘息の重症度の指標になりうると 考えられた. 今後症例を重㸚より詳細な検 討をしていきたい.
$\mathrm{O} 2$

\section{気管支喘息小児のアレルギ一性鼻炎・喘 息重症度と肺機能との関連}

○本村知華子 1)、久保田典里子 1) 井手康二 1)、手塚純一郎 ${ }^{1)}$ 、小林 博 1 ) 渡辺恭子 1)、岡田賢司 ${ }^{1)}$ 、小田嶋博 1 ) 西間三馨 1)、山田篤伸 2)

1) 国立病院機構福岡病院小児科

2) 山田耳鼻咽喉科医院

【目的】鼻症状と下気道症状との関連は臨 床上よく経験する。今回小児喘息において アレルギー性鼻炎と喘息重症度との関連を 検討した。

【対象と方法】1. H15 年度当院水泳教室に 参加した 6 から 12 歳の喘息児 47 名。7 月と 2 月に耳鼻科医による診察（下甲介粘膜視 診、粘膜色、水性分泌、鼻汁性状)、鼻汁好 酸球検査、肺機能検査 (FVC, FEV 1, PEFR, $\mathrm{V}_{50}$ ）、発作程度、治療内容調査を行い、の ベ77回を対象として検討した。2.2 回とも 参加した 30 例では鼻炎、喘息重症度の変化 の関連についても検討した。

【結果】1. 喘息重症度は間欠型 35 例、軽症 持続型 15 例、中等症持続型 24 例、重症持 続型 3 例。アレルギー性鼻炎重症度は鼻炎 なし 18 例、軽症 34 例、中等症 19 例、重症 6 例。鼻粘膜色の蒼白所見が強いが強いと $\mathrm{FEV}_{1}, \mathrm{PEFR}, \mathrm{V}_{50}$ が低值であった。水性分泌 の程度や鼻汁好酸球、喘息重症度と肺機能 検査には関連はなかった。2.鼻炎重症度と 喘息の重症度の変化、肺機能の変化には関 連はなかった。

【結論】喘息児の鼻粘膜蒼白所見は気管支 の閉塞性変化に関連している可能性があり、 喘息と鼻炎との関連が考えられた。また半 年間の鼻炎と喘息重症度変化には有意な関 連はなかった。 
$\mathrm{O} 3$

\section{気管支喘息小児におけるアセチルコリン 吸入負荷試験の臨床的検討}

○山田桂太郎、近藤富雄、小関道夫 有木真子、岩田晶子、岩田秀樹 山崎松孝

\section{大垣市民病院 第 1 小児科}

アセチルコリン (Ach) 吸入負荷試験は小 児においても気管支喘息の病態、経過など の状態把握に有効な検査である。われわれ の今までの検討では、Ach吸入負荷後の $\beta$ 2 刺激薬吸入直後の肺活量 $(\mathrm{FCV}) 、 1$ 秒量 (FEV1.0)、V50、V25 の改善率が高い例程、 気道過敏性が六進し、重症であった。今回 は外来フォロー中の患児 22 例に対し、Ach 吸入負荷試験を経時的に行い、各症例ごと にAch 吸入負荷後の $\beta 2$ 刺激薬吸入直後の FCV、FEV1.0、V50、V25の改善率と、臨 床的重症度などとの関連を検討した。約 $1 / 3$ の症例で重症度の改善とともに FCV、 FEV1.0、V50、V25 改善率の関連がみられ た。他の例は不変、あるいは臨床的には改 善しているものの検査上は悪化が認められ た。Ach 吸入負荷試験は一部で臨床的重症 度と関連しない例もみられたが、気管支喘 息患児に対する臨床的重症度の経過を追う のに有用な検査であると思われた。
O4

\section{副腎不全を発症した重症難治性乳児喘息 の一例}

\author{
$\bigcirc$ 奥 典宏 ${ }^{1)}$ 、新田啓三 1)、菅井和子 1,2 , \\ 池部敏市1)
}

1)横浜南共済病院小児科

2)藤沢市民病院小児科

症例は 2 歳、女児。生後 11 ケ月で喘息発 症、当院初診 11 ケ月 (平成 15 年 1 月)。乙 の後 3 ケ月間で 4 回喘息発作入院を繰り返 したため、平成 15 年 4 月再入院。入院後も 重積発作が 3 度有り、胸部 CTにて間質性肺 炎像を認めたため、プレドニゾロン(PSL)の 全身投与を継続したところ症状は改善した。 PSL $0.5 \mathrm{mg} / \mathrm{kg} /$ day 内服、ベクロメサゾン 300

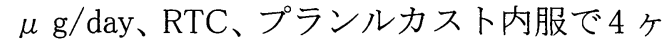
月後に(8月)に退院した。その後、PSLは 漸減中止し外来フォローされていたが、平 成 16 年 2 月に発作で再入院となった。PSL 内服再開、フルチカゾン (FP) $300 \mu \mathrm{g} / \mathrm{day}$ 、ア ミノフィリン持続点滴などを行ったが、 2 ケ月余りの間に 4 度重積発作を起こした。 喘息のコントロール不良例と考え、4月よ りFP900 $\mu \mathrm{g} /$ day 吸入を開始し、PSL内服は 漸減しつつ継続したところ、喘息発作は見 られなかった。しかし、5月に発熱、嘔吐、 痤攣、電解質異常が認められ、副腎不全症 状が疑われた。ACTH負荷、CRH負荷で間 脳一下垂体一副腎系の抑制を認めた。ハイド ロコルチゾンを補充する一方、PSL内服を 中止し、FPも減量し、6月に退院した。現 在FP300 $\mu \mathrm{g} /$ day、プランルカスト、IPD内 服にて喘息発作の再発はない。長期ステロ イド全身投与やFP大量療法を必要とする 重症乳児喘息に対しては、副腎機能に関し て十分に留意する必要がある。 
$\mathrm{O} 5$

\section{補体系 C3、C3AR1、C5 遺伝子の多型は 喘息発症リスクに影響する}

○鎌田文顕 1$)$ 、鈴木洋一 1)、青木洋子 1) 呉 繁夫 1)、松原洋一 1)、長谷川耕一2) 玉利真由美 2 、白川太郎 2,3)

1) 東北大学大学院 医学系研究科 小児医学講座 遺伝病学分野、2) 理化学研究所 遺伝子多型研究 センター、3)京都大学大学院 医学系研究科 健 康要因学講座 健康増進・行動学分野

近年、補体のノックアウトマウスの実験 結果や、人における喘息誘発時の気管洗浄 液中のC3、C5の上昇などの観察から、気 道の炎症、過敏性を中心とする喘息の病態 に補体系が関与していることが示唆されて いる。我々は、補体 C3、C5 とその分解産 物の受容体の遺伝子多型が喘息発症のリス クに関係しているかどうかを明らかにする ため、C3、C5、C3a受容体 (C3AR1)、C5a 受容体 (C5R1) の遺伝子の一塩基多型 (SNP) を検索し、それらが小児喘息や成人喘息発 症に与える影響について検討した。C3、C5、 C3aR、C5aR遺伝子のそれぞれ、4、5、2、 2 個のSNPを検討したところ、SNP単独では、 C3 4896C/Tとアトピー性小児喘息、成人喘 息との相関が認められた。また、C3aR 1526G/A と最重症の小児喘息との相関も認 められた。複数のSNPで形成されるハプロ タイプを構築して検討すると、C3では、小 児喘息、成人喘息の発症リスクを上げるハ プロタイプの、C5では、小巟喘息、成人喘 息の発症リスクを下げるハプロタイプの存 在が明らかになった。以上の結果から、喘 息発症における補体系の関与が示唆された。
O6

\section{小児気管支喘息におけるアラキドン酸 関連遺伝子多型とロイコトリエンの動向}

1)岐阜大学 大学院 医学研究科 小览病態学

2) 木澤記念病院 小览科

3) 西美濃厚生病院 小览科

【目的】ロイコトリエン( leukotrienes; LTs)、 プロスタグランジン ( prostaglandins; PGs)、

トロンボキサン (thromboxane; TX)などの アラキドン酸代謝産物は顆粒球系細胞を含 む種々の細胞に存在し、生理活性物質とし て、多岐にわたり重要な役割を果たしてい る。LTsの喘息の病態に占める重要性から、 喘息の治療薬としてLTs 受容体拮抗薬が開 発され、コントローラーとしての有用性が 確立してきた。そこで、LTs 産生に関与す る䤉素遺伝子多型の検討を行ない、薬理遺 伝学的立場より検討することを目的とした。

【対象および方法】小児気管支喘息患者を 対象にした。対象者の好中球より抽出した DNAを用いて、アラキドン酸代謝系に存在 する酵素をコードする遺伝子のなかで、5lipoxygenase, LTA4 hydrolase, LTC4 synthase の遺伝子配列を検討した。さらに、 尿中LTE4、11-dehydro-TXB2 排泄量との関 連についても検討を加えた。

【結果および考察】5- lipoxygenase，LTA4 hydrolase, LTC4 synthase の遺伝子配列の 検討で、いくつかのSNPを同定した。同定 したそれぞれのSNPの頻度を気管支喘息群、 コントロール群で比較するとともに、尿中 のロイコトリエン排泄量、トロンボキ酸排 泄量の比較を行なった。これらの結果を文 献的考察をふまえて報告する。 
O7

\section{軽症気管支喘息児における呼気中ロイコ トリエンレベルの検討}

○柴田 淳、勝沼俊雄、赤司賢一 衛藤義勝

東京慈恵会医科大学 小児科

【背 景】Cysteinyl leukotriens (cys-LTs; LTC4, LTD4, LTE4) は喘息における気道炎 症やリモデリングに関与する重要なメディ エーターとして注目されている。一方で「軽 症喘息」が、新たな臨床上の問題として世 界的規模で議論されている。今回我々は気 道LTs レベルをより直接的に反映すると考 えられる呼気中LTsを小児において測定す るシステムを開発し、軽症喘息児を対象に 検討した。

【方法】軽症喘息児 37 名（8～18歳）を対 象に、呼気中および尿中のLTE4を測定した。 対象者はさらにメサコリンに対する気道反 応性加ら、気道過敏性非六進群（15名、 PC15 > $0.25 \mathrm{mg} / \mathrm{ml}$ ) と六進群 (15名、PC15 $<0.25 \mathrm{mg} / \mathrm{ml}$ )、および喘鳴群（7名）の3 群に分類した。非喘息児 6名 (平均 10．3 歳）を対照として比較検討した。

【結果】軽症喘息児の呼気中LTE4は対照に 比し有意に上昇していた $(5.69+1.60$ versus $0.74+0.34 \mathrm{pg} / 20 \mathrm{~min}, \mathrm{p}<0.05)$ 。特に 気道過敏性元進群、喘鳴群においては高値 であった（各 $5.31+1.92 、 14.66+6.98 ; p$ $<0.05)$ 。尿中 LTE4 值は、各群間で有意な 差を認めなかった。

【考案】LTは小坚の気管支喘息において、 しかも無症状・軽症な段階からその病態に 関与することが示唆された。呼気中LT測定 は非侵襲的かつ気道炎症をより直接的に反 映する有用なマーカーとして活用可能であ ると考えられた。
$\mathrm{O} 8$

\section{小児気管支喘息における気道炎症の評価 〜呼気中NOおよび高張食塩水による 誘発喀痰を用いて〜}

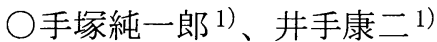
久保田典里子 1 )、小林 博 1 ) 本村知華子 1)、岡田賢司 1)、小田嶋博 1) 下田照文 ${ }^{2)}$ 、西間三馨 ${ }^{1)}$

\section{1) 国立病院機構 福岡病院 小少科 2) 国立病院機構 福岡病院 内科}

【目的】気管支喘息は、その重症度に関わ りなく気道の慢性炎症性疾患である。現在、 喘息の長期管理薬は抗炎症薬を主体とした ものとなっており、気道炎症の評価は、喘 息の診断・長期管理の指標として重要なも のである。非侵襲的な気道炎症の評価方法 の代表的なものとして、呼気中 $N O$ 濃度測 定・高張食塩水による誘発喀痰分析を行い、 その有用性について検討を行った。

【方法】当院外来でフォローアップ中の喘 息患児を対象とし、アセチルコリンを用い た標準法での気道過敏性検査を行う際、検 査前に呼気中 $N O$ 濃度を測定し、検査後に 高張食塩水吸入による誘発喀痰を採取し分 析した。

【結論】呼気中 $N O$ 濃度と誘発喀痰中の好 酸球の百分率は相関係数 $\mathrm{r}=0.74 （ \mathrm{p}<0.01)$ と強い相関を認めた。標準法による気道過 敏性との関係・誘発喀痰中のサイトカイン 分析の結果も併せて報告する。 
O9

焱症細胞機能の活性単位の規格化

$\bigcirc$ 今泉 晃 ${ }^{1,2)}$ 、中村明夫 ${ }^{1)}$ 、松藤理恵 ${ }^{1,2}$ 蓮見賢一郎 2 )、柳川幸重 ${ }^{1)}$

1) 帝京大学 小児科、2）（医）珠光会

【目的】小児科領域において気道の炎症は 気管支喘息の進展増悪の危険因子となりう る。従って、治療計画を立てるに当たり炎 症の進行のターニングポイントを予測する ことは、その後の治療計画を立てるうえで 大きな助けとなりうる。我々は、炎症時に おける動的なファクターとして食機能をも つ免疫細胞の活性単位の継時的な変化を追 跡するため、該当細胞の活性単位の規格化 を試みた。通常、免疫という複雑な生体内 での代謝機構を経た結果である「生体現象」 を規格数值化することは、介在する因子の 多さから難しいとされてきた。我々は、こ のテーマの解決の糸口として、マクロ ファージ領食賦活活性を規格数值化する試 みをおこなった。

【方法】標準物質としてコレラ毒素ユニッ トBを用いた。被験物質はマウス皮下に投 与した。薬剤投与マウスマクロファージは 蛍光ラテックスビーズと 2 時間培養し領食 させた。貪食の測定にはFlowcytometryを使 用し貪食データを数值化した。

【成績と結論】1)コレラ毒素ユニットB （CTx）は、投与された濃度に依存してマ クロファージの䕘食能を六進する。2）CTx を用い標準曲線を作成した。独立した実験 間においての比較では、最大反応誘導濃度 の半值は、同一ロットのCTxではほぼ同じ 值を示した。3）同一ロットのCTxにて作 成された標準曲線に基づき、未知の被験物 質の生体における貪食方進活性単位を算出 できる。
$\mathrm{O} 10$

小児気管支喘息患者の入院時間帯の検討

○鶴田 靖、石崎典子

三沢市立三沢病院 小巟科

【目的】ガイドライン準拠、吸入ステロイ ド導入により当科の小児気管支喘息患者の 入院数は年々減少傾向にあるが、夜間や休 日の入院の占める割合は少なくない。今回、 喘息児の時間外や休日の入院の頻度につい て調査することを目的とした。

【対象および方法】2000 年〜 2003 年に気管 支喘息発作で当科に入院した 8 ケ月〜 14 歳

(3.3歳士 3.1 歳) 105 例を対象に入院時間に ついて検討した。

【結果】105例の入院のうち平日（月〜金 曜日）67例、休日（土、日、祝祭日）38例 で、平日時間内 $(9 \sim 17$ 時) は 49 例 $(47 \%)$ 、 休日および時間外は 56 例 $(53 \%)$ 、深夜

(22〜6時) の入院は 14 例 $(13 \%)$ であつ た。時間帯では平日では 11 時、16時に多く、 時間外では 21 時に多かった。入院の内訳は 近隣の一次医療機関からの紹介やその通院 患者が多く、初発の喘息発作や夜間の大発 作も含まれていた。

【考察および結論】喘息症状の好発時間は 夜間から早朝にかけて多いが、喘息児の入 院の時間帯についても時間外や休日の頻度 が高かった。患者と家族、および小児科医 を含めた医療側の負担を考慮すると、日中 のうちに夜間や休日を視野に入れた喘息児 の十分な管理・指導が必要と考えられた。 
$\mathrm{O} 11$

\section{国立大竹病院小児科救急外来受診喘息発 作有症児と気象観測值の関係の検討 第2 報}

○大黒一成、岡畠宏易

独立行政法人 国立病院機構 大竹病院 小巟科

【目的】我々はこれまでに，1992年から 2001 年までの 10 年間に当科救急外来を受 診した喘息発作患児を対象として, 喘息発 作発症と気象観測值との関係を検討し, 報 告してきた（第 40 回本学会）。今回は, 同 10 年間において期間を秋季（9月〜 11月） に限定し，喘息発作発症と気圧配置との関 連について検討したので報告する。

【方法】1992年から 2001 年までの秋季 (9 月〜 11月）に，当科救急外来を受診した喘 息発作患児 621 名を対象とした。喘息発作 発症を認めた日およびその前後について, 気象庁発表の天気図を用いて気圧配置との 関連を検討した。

【結果】日本の秋季の気候は移動性高気圧 によって天気が周期的に変化することと台 風の襲来が特徵的であるが，(1)移動性高気 圧が通過する前に喘息発作が起きやすく, 高気圧が通りぬけて天気が崩れると発作は 減少する $<65.1 \%>$, (2)台風が通り過ぎて, いわゆる「台風一過」の晴天の日に発作が 起きやすい<71.4\%>, また，(3)台風が近 づく前の晴天の日にも発作は起きやすいく $50.0 \%>$, という結果を得た。（＜>内の数 值は，各々の条件を満たした日に喘息発作 患児が救急外来を受診した日の割合を示 す。)

【考案】1992年から 2001 年までの 10 年間の 秋季における喘息発作発症と気圧配置との 関連について検討したが，喘息発作発症は 多元的要因を含むものであり，今後の更な る検討を必要とする。
$\mathrm{O} 12$

奄美大島の小学生におけるアレルギ一疾 患有症率の1992 年と 2002 年の比較

○中村 亨1)、小林 博 2)

1) 国分生協病院 小览科

2)国立病院機構福岡病院 小児科

【目的】小児においてアレルギ一疾患が増 加していることは世界的にも言われている ことであるが、奄美大島の小学生において もアレルギー疾患が増加しているか検討し た。

【対象および方法】1992年および 2002 年に 奄美大島本島の 27 の同じ小学校の全児童 を対象に調査票、ATS - DLD 日本版・改訂 版を配布、回収し調查を行った。回収率お よび解析対象者数は、1992年が $88.09 \%$ 、 4217 名。2002 年が $86.77 \% 、 2793$ 名であっ た。

【結果および考察】1992 年および2002年の アレルギー疾患の有症率はそれぞれ、気管 支喘息が $4.72 \% 、 6.87 \%$ 。アトピー性皮膚 炎が 8.28\%、8.70\%。アレルギー性鼻炎が $11.19 \% 、 17.61 \%$ 。アレルギー性結膜炎が $2.68 \% 、 4.55 \%$ 。スギ花粉症が $1.35 \% 、 2.15 \%$ であった。1992 年と 2002 年の結果を比較す ると、アトピー性皮膚炎は差がなく、他の アレルギー疾患はいずれも 2002 年の方が 有意に高率で増加していた。また 2002 年の 結果について、同時期に同じ調查票を用い て九州 7 県および沖繩、山口、香川、兵庫 の 81 小学校を対象に行われた西日本小児 アレルギー研究会の結果と比較すると、気 管支喘息は同程度であったが、他のアレル ギー疾患はいずれも奄美大島の方が有意に 低率であった。 
$\mathrm{O} 13$

\section{母乳栄養が乳幼児期のアレルギー疾患に 及ぼす影響に関する検討}

篠原示和 1$)$ 、脇口 宏 ${ }^{2)}$ 、斎藤博久 ${ }^{1)}$
松本健治 1$)$

1) 国立成育医療センター研究所 免疫アレルギー 研究部

2) 高知大学 小児思春期学教室

【目的】母乳栄養は、幼児期の喘鳴性疾患 を抑制する（Siltanen M, Allergy 2003）一方 で、成人期の気管支喘息を促進する（Sears MR, Lancet 2002） と報告されており、この 現象には喘鳴の病態の年齢による相違が関 与寸る可能性が考えられる。今回私達は、 母乳栄養が乳幼児期の喘鳴性疾患やアレル ギー疾患の発症に及ぼす影響について、感 染症の交絡因子の影響を含めて検討した。

【対象と方法】大規模検診に参加した生後 7 ケ月以上の乳幼児 1,358 名（平均月齢 11.2 ケ月）の保護者を対象として質問紙法 にて児の栄養方法や環境因子について調査 し、ロジスティック回帰分析にて解析した。

【結果】家族歴のある母乳栄養児において、 喘鳴性疾患の頻度は $3.4 \%$ で人工栄養児の $8.8 \%$ と比して有意に低值であったが $(\mathrm{p}=0.029)$ 、その他の疾患で有意差はな かった。一方これらの児では、人工栄養児 に比して気管支炎の罹患 (4.7\% vs $11.9 \%$, $\mathrm{p}=0.016)$ 及び託児所の利用 $(8.4 \%$ vs $17.8 \%$, $\mathrm{p}=0.011$ ）が有意に低かった。気管支炎の発 症と託児所利用を考慮に入れたロジス ティック回帰分析では、母乳栄養はアレル ギ一疾患の発症に有意な影響は認められな かった。又家族歴のない児での同様の検討 では、いずれの場合においても有意差はな かった。

【結論】母乳栄養児では託児所の利用率が 低く、そのために感染の頻度が低下して乳 幼児期の喘鳴性疾患の発症が低下するが、

これらの因子を考慮するとアレルギー疾患 の発症には影響を与えない可能性が示唆さ れた。
$\mathrm{O} 14$

\section{2 歳以下に頻回入院を要した喘息児の臨 床的検討}

\author{
○曽根尚子、渡辺美砂、内野由美子 \\ 中村久理子、竹内邦子、藤原摩耶 \\ 田中晶子、柳川 進、岡本則彦 \\ 波多野道弘、月本一郎
}

東邦大学 医学部 第一小児科

【目的】気管支喘息の有症率、なかでも乳 児喘息は近年増加傾向にある。今回 2 歳以 下に頻回入院した喘息児の臨床像と予後に ついて検討を行った。

【対象と方法】対象は 1995 年〜 2000 年に 2 歳以下で 3 回以上の入院加療を要した喘息 児 37 名。（調査時平均年齢 7.5 歳。）後方視 的に診療記録を調査し、またアンケート調 查を行った（回答率 $32 \%$ )。

【結果と考案】男女比 $25: 12$ 、平均発症月 例 12.5 ケ月。2歳以下の重症度は 2000 年の 小児気管支喘息治療・管理ガイドラインで 中等症 23 例、重症 14 例。平均好酸球数 $802 /$ $\mu \mathrm{l}$ 、平均 $\mathrm{IgE}$ 值 $352 \mathrm{IU} / \mathrm{ml}^{\circ}$ 。テオフィリン製 剂内服 $100 \%$ 、LT受容体拮抗薬内服 $57 \%$ 、 DSCG 吸入 $89 \%$ 、吸入ステロイド $59 \%$ 。発 症から使用開始までの平均期間はLT受容 体拮抗薬 19.3 ケ、吸入ステロイド薬 15.5 ケ月。

現在の重症度は、寛解 7 例、間欠型 8 例、 軽症持続型 8 例、中等症持続型 3 例、重症 持続型 1 例（不明 10 例）。寛解、間欠型を 良好群、軽症持続型、中等症持続型、重症 持続型を不良群として予後の違いによる臨 床像を比較したが有意差は認められなかっ た。2歳以下の重症度は不良群で有意に高 かった。LT拮抗薬の使用率は、不良群で $83 \%$ と有意に高く、使用開始までの期間は 良好群で有意に短かった。

2 歳以下の重症度が予後に与える影響は 大きく、また早期の LT 拮抗薬の使用により 予後が改善される可能性が示唆された。 
$\mathrm{O} 15$

\section{重症発作が遷延した乳児喘息の4 例}

$\bigcirc$ 西野昌光、橋本直樹、三宅理、南 宏尚 李 容桂、根岸宏邦、三輪明弘 竹中佳奈栄、榎本真宏、増田淳司
$\mathrm{O} 16$

\section{2歳未満で喘息や喘息様気管支炎の診断 で入院加療をうけた小児の予後調査}

○中嶋直樹、荒川浩一、水野隆久 滝沢环己、望月博之、徳山研一 森川昭廣
特定医療法人愛仁会 高槻病院 小巟科

【はじめに】小巟気管支喘息治療・管理ガ イドラインでも 2 歳未満の乳幼児は、その 病態・治療において一線を画されている。 今回重症発作が遷延した 1 歳未満の乳児喘 息 4 例を経験したので、その病態について の考察を加えて報告する。

【症例】症例 1 は超低出生体重の女児、症 例 2 は極低出生体重の男児、残る症例 3,4 は成熟児の男児。いずれもウイルスの下気 道感染の既往があり、生後 $4 \sim 10$ ケ月の間 に喘鳴・呼吸困難で発症。アミノフィリン 持続点滴（1例を除く）、サルブタモール吸 入、酸素投与で治療開始し、ステロイド静 脈内投与も併用、喘鳴消失のためにロイコ トリエン拮抗剤、ステロイド吸入を要し、 発作軽快までに 1 週間〜数週間を要した。 基礎疾患は症例 1 が未熟児の慢性肺疾患、 生後 7 ヶ月時にインフルエンザに罹患、症 例 2 は軽症の新生児一過性多呼吸、慢性肺 疾患は発症せず、生後 5 ケ月で、細気管支 炎様症状で入院、生後 8 ケ月より喘鳴・呼 吸困難で発症。症例 3 は軽症の新生児一過 性多呼吸、生後 1.5 ケ月と 2 ケ月時、細気 管支炎罹患し、3.5 ケ月で喘息発症。症例 4 は成熟児男児で、生後 4.5 ヶ月時にウイル ス感染による喘息様気管支炎症状で発症し、 経過中に喘鳴・呼吸困難増強し、喘息発症。

【考察】呼吸器系の基礎疾患を有したり、 下気道感染を反復する乳幼児では、喘息の 発症に際して早期の病態把握と治療介入を 行い、症状の遷延化を防止する必要がある。
群馬大学 大学院 小児生体防御学

乳児喘息は、一部は典型的喘息となり早 期介入を考慮す心゙き例も見られるが、成長 とともに消失する予後良好群も多い。

【目的】今回、2歳未満で喘息や喘息様気 管支炎の診断で入院加療をうけた乳児の予 後調査を行い、予後予測因子を検討した。

【方法】対象は、富岡総合病院小児科で、 1994年から 1999年の間に2歳未満で初回入 院した 72 名（男 49、女 $23 、 13 \pm 7$ 力月） で、初回入院時の総 $\mathrm{IgE}$ 值、ダニ特異的 $\mathrm{IgE}$ 值、 2004 年 3 月（最終月齢：92 \pm 16 力月） までの入院歴、テオフィリンを処方された 最終年齢などを後方視的に調查した。

【結果】初回入院のみの児は 23 名、2回入 院した児は 22 名、3 回以上入院した児は 27 名であった。3回以上入院群で、3歳以下で テオフィリンを中止できた児（早期群）は 7 名、4歳以上も使用しているが、ここ 2 年 間以上テオフィリンを処方されなかった児 (中間群) が 4 名、テオフィリンを継続し ている览 (RTC群) は16名であった。総 $\mathrm{IgE}$ 值は、早期群で平均 $81 \mathrm{IU} / \mathrm{ml}$ 、中間群で $59 \mathrm{IU} / \mathrm{ml}$ 、RTC 群は $438 \mathrm{IU} / \mathrm{ml}_{\text {。 }}$ ダニ特異 $\mathrm{IgE}$ 抗体は、早期群と中閒群では全例陰性で、 RTC 群は 16 名中 11 名が陽性であった。

【結論】2歳未満で入院加療をうけた小児 においても、約 60\%は早期群で予後良好で あると思われた。ダニ陽性群ではいわゆる 喘息として継続治療が必要となる可能性が 示唆された。 
$\mathrm{O} 17$

\section{アレルギー外来長期経過観察児の病院閉 鎖後の転帰}

横内裕佳子

\section{$\mathrm{O} 18$}

\section{乳幼児期早期に気管支喘息を疑われた児 における鼻疾患鑑別の重要性についての 検討}

○西川嘉英、吉田之範、亀田 誠 高松 勇、土居 悟

\section{東京都立広尾病院 小児科}

都立母子保健院は昭和 17 年に東京市立 乳児院世田谷保育館として開設され、昭和 35 年に母子保健院として産婦人科、小児科、 新生児科、乳児養育科が整備されて以後近 年は年間 1000 近い出生数と小児科入院数 があり、世田谷区で唯一 24 時間態勢の小児 科救急診療を行うなど、平成 13 年の都立病 院改革マスタープラン策定により平成 14 年 12 月に閉院されるまで、地域の母子専門 医療施設として機能してきた。今回、母子 保健院閉院時にアレルギー外来に定期的に 通院していたアレルギー性疾患を有する患 児のうち、紹介状とともに他院へ紹介した 94 名の 1 年後の通院状況と現在の症状、治 療内容等についてアンケートを送付し、回 答の得られた 52 名（住所不定で返送された 8 名を除くと回答率は $60 \%$ ）について検討 した。現在定期的に通院している患児のう ち月 1 回以上の受診が 24 名 $(46 \%)$ 、年数 回が 23 名 (44\%) 受診先が不定であるある いは定期的には受診していないと回答した のは 5 例 (9.6\%) でありそのうち3 例は アトピー性皮膚炎のみであるが、1例は中 等症持続型、1 例は軽症持続型喘息であっ た。気管支喘息症例のうち軽症型、特に軽 症間欠型症例では専門性の高い施設への紹 介症例で継続治療例が多く、一般開業小児 科への紹介例で間欠的な治療を行われてい る症例が多い傾向にあった。今後、紹介時 の重症度や年齢なども加味し、検討の上報 告の予定である。
大阪府立呼吸器・アレルギー医療センター小児科

【はじめに】乳幼児は気管支喘息（以下喘 息）様の症状を呈することが多く、診断に 苦慮する。喘息と思われる症例の中には鼻 症状が主で鼻治療により喘息様症状が消失 したり、喘息治療を軽減できる場合も多い。 今回、乳幼児期早期の鼻疾患鑑別の重要性 につき検討した。

【対象と方法】平成 15 年に当科を初診した $0 \sim 2$ 歳児の内、喘息を疑われ当科を受診し 初診時に鼻疾患を疑った児で、以後継続観 察が可能であった 76名を対象とした。原則 として鼻汁培養・好酸球検査等を行い、そ の臨床症状とともに評価した。

【結果】対象 76 名の年齢は、0歳 22 名、1歳 29 名、2歳 25 名。初診時問診よる喘息の程度 は、咳嗽のみ 6 名、(小児アレルギー学会基 準）小発作 25 名、中発作以上 45 名。鼻汁 培養検査では、B.catarrhalis, S.pneumoniae, H.influenzae 等の菌をほぼ全例で検出。鼻汁 中好酸球検査では $40.9 \%$ が陽性であった。ま た最終的に、喘息・喘息が主と診断できた のは、34例 (44.7\%)、鼻疾患のみ・喘息はあ るが鼻疾患が主と診断したものが 42 例 (55.3\%)であった。

【まとめ】今回、乳幼児早期に喘息を疑わ れた児を対象にその鼻疾患の関与につき検 討したが、喘息と思われる症例の中には鼻 疾患の関与が多く、的確に診断・治療する ことが重要であると考えられた。これらの 症例については今後更に追跡検討していく 予定である。 
$\mathrm{O} 19$

\section{当院で経験した主要な喘鳴の鑑別疾患}

○井手康二、本村知華子、手塚純一郎 久保田典里子、小林 博、渡辺恭子 岡田賢司、柴田瑠美子、小田嶋博 西間三馨

国立病院機構福岡病院

【はじめに】小児において喘鳴を生じうる 疾患は極めて多様であり、おもだった胸腔 内疾患で喘鳴を絶対に生じない疾患をあげ るのはむずかしいほどである。しかし我々 は喘鳴＝気管支喘息と思いがちで、その他 の疾患を見逃す危険性がある。

【方法】過去 10 年間において当院に喘鳴を 主訴に来院し、気管支喘息以外の疾患で あった症例をまとめ検討した。

【結果】喘鳴の原因は幅広く、その中でも 気胸、腫瘍など見逃すと重症化するものが 多く認められた。

【結論】喘鳴のみで気管支喘息と診断され 喘息の治療を受けていた例が多く、喘鳴の 鑑別診断は非常に重要であり、安易な喘息 との診断はその他の喘鳴を伴う疾患を見逃 す可能性が高く注意を要すると考えられた。
$\mathrm{O} 20$

NICUを退院した超未熟児における冬季 呼吸器症状による入院率の検討（パリビ ズマブ投与効果を中心に)

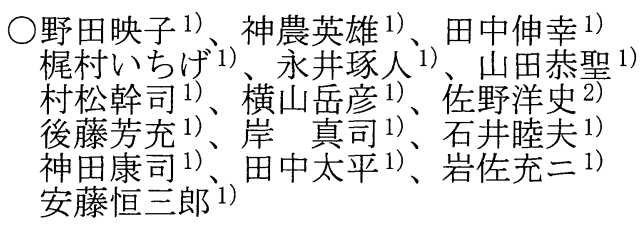

1)名古屋第二赤十字病院 小児科

2)さの すこやか クリニック

【目的】RSウイルス（RSV）は、乳児期で の下気道感染の原因となり、その後の乳児 喘鳴の発症に関与していると考えられてい る。基礎疾患を有する児では重症化しやす い。2002 年、RSVに特異的に結合するヒト 化モノクローナル抗体（パリビズマブ）の 予防投与が承認され、当院でも八イリスク 児に使用されるようになった。今回我々は 当院 NICUを退院した超未熟児の RSV 感染 流行期のパリビズマブ予防投与効果につい て検討したので報告する。

【対象および方法】在胎 28 週未満かつ出生 体重 $1000 \mathrm{~g}$ 未満の超未熟児 48例のうち 1995 年 1 月から 2000 年 9 月までに出生した非投 与群 23 例と 2000 年 10 月から 2003 年 9 月ま でに出生した投与群 25 例に分類し、3 歳未 満までの呼吸器症状による入院率を比較検 討した。

【結果】非投与群 23 例中 8 例が、投与群 25 例中 1 例が RSV 流行期（11月から翌年 3 月 まで）に呼吸器症状により入院した。

【考察】パリビズマブ予防投与は超未熟児 の RSV 感染流行期の入院率を低下させるこ とが示された。このことはハイリスク児に おいて後年繰り返す喘鳴等の呼吸器症状の 軽減につながる可能性があると期待される。 


\section{$\mathrm{O} 21$}

\section{小児の喘息増悪における上気道ウィルス 感染の関与}

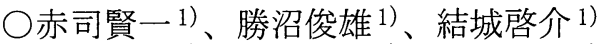
丹 愛子 2)、柴田 淳 1)、阿部法子 1) 豊田 茂 2 )、橋本光司 3 )、今村直人 4 ) 衛藤義勝 1 )

1) 東京慈恵会医科大学 小児科、2)神奈川県衛生 看護専門学校附属病院 小児科、3) 日本大学光が 丘病院 小児科、4)鹿児島大学 小児科

【目的】われわれは喘息児を対象に，喘息 発作 (増悪) における上気道ウィルス感染 の関与につき，ライノウイルス (rhinovirus; RV と略）を中心に検討を進めてきた.

【方法】 2002 年 10 月から 2004 年 5 月まで, 東京慈恵会医科大学小児科アレルギー外来, 神奈川県衛生看護専門学校付属病院小児科 外来，日本大学光が丘病院小児科アレル ギー外来，鹿児島大学小児科アレルギー外 来に喘息発作（増悪）で来院した児（151 人, 男女 $99 / 52$ ，平均年齢 6.0 歳）を対象に， 文書による同意取得後, 鼻汁上気道ウイル スの同定を行なった。鼻汁サンプルはRNA 保存液中で冷凍保存後，RT-PCRを施行し た。

【結果】RV陽性者の喘息重症度は，間欠型 から中等症持続型まで分布していたが，初 発も $33 \%$ に認められた。発作重症度は喘鳴 のみ呈する例から大発作まで幅広く認めら れた。 月 (季節) 別の検討では，冬季（12 月〜2月）の検出率は低かったが，他の月 は30\%以上の検出率であった。年齢層別の 検討では，0～ 2 歳で $41 \% ， 3 \sim 5$ 歳で 30\%, $6 \sim 12$ 歳で $51 \%, 12$ 歳以上の年長では $75 \%$ が RV陽性であった。

【結論】小児気管支喘息の増悪においては、 年齢・重症度に関わらずRV感染の関与が少 なくない，従来指摘されてきた年長〜成人 のみならず, 乳幼児や初発が疑われる症例 においてもその関与が示唆された。
$\mathrm{O} 22$

\section{RSV 感染症による小児喘鳴性疾患の 545 例の検討}

$\bigcirc$ 植村幹二郎 1,2$)$ 、西尾久英 ${ }^{2)}$

\section{1)うえむら小児科内科クリニック \\ 2)神戸大学 医学部 環境応答医学}

【はじめに】Respiratory syncytial virus (RSV) 感染症は日本の冬季の極めてポピュラーな 疾患であり、喘鳴を生じる感染症の代表的 なものである。また喘息との関係が重要と 言われながらも、保険の問題からか外来レ ベルで正確な診断がなされていないのが現 状である。

【対象及び方法】平成 $10 / 11$ 年から 15 16 年までの冬季 6 シーズンに当院外来を受 診した 6 歳以下の下気道感染症児 2506 例を 対象とした。鼻腔吸引液中の RSVを迅速診 断法にて検索した。

【結果】RSV 陽性は 2506 例中 1239 例 (49.4 \%) で、RSV 陽性例のうち喘鳴を認めた 545 例を検討した。急性細気管支炎は545例中 25 例 $(4.6 \%)$ 、喘鳴を伴う気管支炎/肺炎

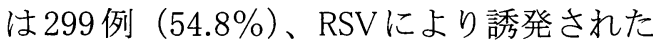
喘息発作は 221 例 $(40.6 \%)$ であった。そ れぞれの発症時の月齢 $(\mathrm{M} \pm \mathrm{SD})$ は $3.8 \pm 2.9$ 、 $17.5 \pm 11.4 、 33.8 \pm 15.6$ ケ月であった。入 院を要した児はそれぞれ 25 例、33 例、34 例と 6 年間で合計 92 例になった。

【考察及び結語】 RSV 感染による喘鳴性疾 患は小児科外来に数多く受診しているが、 細気管支炎以外はその病態や治療方針は全 く論じられていない。入院を要することも 多く、病態の理解および治療の確立が望ま れる。 
$\mathrm{O} 23$

\section{小児喘息発作誘発におけるHuman Metapneumovirusの関与についての検 討}

○高橋 豊 ${ }^{1)}$ 、佐藤宏紀 ${ }^{1)}$ 、川原朋乃 1) 藤原ふみえ ${ }^{1)}$ 、鹿野高明 1)、海老原敬 ${ }^{2)}$ 菊田英明 2 )

1)幌南病院

2) 北海道大学医学部小児科

【目的】Rhinovirus やRS virusなど種々のウ イルスが小児喘息の発作誘発に関与するこ とが知られている。今回我々は 2001 年に発 見されたHuman Metapneumovirus (hMPV)が 小児の喘息発作誘発に関わるか否かについ て検討した。

【対象と方法】対象は当科に発作で受診し た喘息患児 58 例で年齢は 11 ケから 9 歳 9 ヶ月 (平均 3 歳 8 ケ月)、性別は男児が 44 例 $(75.9 \%)$ であった。患児の鼻汁の RS 抗 原をEIA迅速診断キットにて検索した後、 陰性例について鼻汁中 hMPVをRT-PCR 法 により検出した。PrimerはFusion protein の conserve regionより作成したものを用いた。

【結果】対象となった喘息患児 58 例中 30 例 (51.7\%) は $38^{\circ} \mathrm{C}$ 以上の発熱を認め、20例 (38.5\%) は入院加療となった。6 例 $(10.3 \%)$ の 鼻汁から hMPVが検出された。陽性例と陰 性例で比較すると発熱はそれぞれ 6 例中 5 例 $(83.8 \%) 、 52$ 例中 25 例 $(43.1 \%)$ で認 められ、入院した比率はそれぞれ4例 (66.7\%)、18例（34.6\%）といずれも前者で 高率であったが、その差は有意ではなかっ た $(\mathrm{P}=0.22 、 \mathrm{P}=1.0)$ 。平均月齢はそれぞれ $29.3 \pm 16.7 、 46.3 \pm 25.4$ ケ月であり前者で 少なかったが、この場合もその差は有意で はなかった $(\mathrm{P}=0.056)$ 。

【結論】年少児の喘息発作の一部に HMPV 感染が関与している可能性が示された。
$\mathrm{O} 24$

\section{喘鳴を呈し入院治療を行なった 2 歳未満 の症例における肺炎マイコプラズマ感染 の関与}

\author{
○渡辺晴子 1)、小口 学 1)、鈴木恭子 1) \\ 酒井理恵 1)、斉藤洋平 1)、高田昌亮 1 ) \\ 栗屋敬之 2)、和田万里子 2)、青柳 陽 2$)$ \\ 坂口佐知 2) \\ 1) 東京都立 豊島病院 小児科
2) 順天堂大学 医学部 小览科 恩期
}

【背景・目的】小肾においては、RSV、肺 炎マイコプラズマ $(\mathrm{Mp}) 、$ 肺炎クラミジア などによる下気道感染を契機に喘鳴を呈す ることが多い。今回、2 歳未満で喘鳴を呈 し、入院治療を必要とした症例における $\mathrm{Mp}$ 感染の関与について、一部RSV 感染との比 較も行い検討した。

【方法】Mp 感染の有無は、MpIgM 抗体陽性 $(\mathrm{MpIgM}+)$ により判断し、同検査を導入し た $\mathrm{H} 13$ 年 10 月から $\mathrm{H} 16$ 年 6 月までの入院症 例データベースおよび診療録をもとに検討 を加えた。

【結果】この期間に入院した 2 歳未満の症 例 989 例中 411 例が喘鳴を呈していた。2歳 未満の喘鳴例 411 例 中 MpIgM + は 52 例

(12.7\%)であり、2歳以上の場合の 104/377 例 $(27.6 \%)$ に比べ低率であった。一方、 $\mathrm{MpIgM}+$ 症例 79 例 中喘鳴例 は5 52 例

(65.8\%) と、Mp 感染例においては高率に 喘鳴が生じていた。初回の喘鳴を伴う入院 が 2 歳未満で、複数回の入院歴を有した症 例は 87 例あり、このうち MpIgM + は 30 例、 RSV 感染は 42 例に、Mp、RSV 両者の感染あ りは8例であった。初回の感染時期の平均 を比較すると、RSVの 8.95 ケ月（最年少 1 ケ 月）に対し、 $\mathrm{Mp}$ は 16.2 ヶ月（最年少 7 ヶ 月）と有意な差がみられた。

【結語】2歳未満の症例においてMp感染は、 喘鳴の発症に重要な役割を果たす因子の一 つであり、主に1歳以降においてその関与 が増加するものと考えられた。 
$\mathrm{O} 25$

\section{気管支喘息呼吸機能における一秒量の推 移及び喘鳴症状からの喘息寛解の検討}

○青木国輝、真方浩行、荒井崇彦 弓田 武、許 重治、山口公一 向山徳子

同愛記念病院 小巟科

【はじめに】思春期は、気管支喘息の寛解 を期待できる年齢であるが、様々な要因に より成人喘息に移行していく年齢でもある。 今回、喘息発作時の症状、及び呼吸機能の 点から寛解に至らない要因について検討し たので報告する。

【対象・方法】15歳から 33 歳の思春期喘息 及び成人喘息に移行した患者の呼吸機能検 査における一秒量の加齢による推移につい て検討し、喘息発作時における本人の自覚 症状としての喘鳴に関する調査を行った。

【結果】7歳位では、1500ml 程度であった 一秒量は、成長とともに $13 \sim 16$ 歳位には、 ほとんどの患者で $2500 \mathrm{ml}$ 以上に達した。そ れとともに発作が生じても幼少期の典型的 な症状であった笛声喘鳴は以前より少なく なり、呼吸困難を主体とした発作型に変容 したと感じている患者が大半であった（53 名中 46 名)。また一秒量が $2500 \mathrm{ml}$ 末満の症 例、及び気道過敏性の著明な充進を認め、 発作を繰り返している症例では依然として 喘鳴症状が主体の発作が認められた。

【考察】成長とともに一秒量が増加し気道 径が拡大することにより、発作が生じても 著明な気道狭窄が起こりづらくなる可能性 があり、寛解に至らず成人喘息に移行した 症例の中には発作に対する自覚症状が乏し くなるため、過小治療となっている症例も あると考えられた。思春期〜成人移行期に おいては、喘鳴症状を中心とした発作の程 度の見方から息苦しさを主体とした発作症 状の評価が必要であると考えられた。
O26

寛解状態にある思春期喘息児の末梢気道 閉塞状態の評価とその可逆性に関する検 討

○水野隆久、徳山研一、滝沢环己 小山晴美、西村秀子、荒川浩一 望月博之、森川昭廣

群馬大学 大学院 医学系 小览 生体防御学

【目的】無投薬で発作寛解状態を持続して いる思春期の喘息児における末梢気道閉塞 の程度と、その可逆性の有無について検討 した。

【方法】対象は、無投薬にて経過観察中の 喘息児 37 名 (男 25 名、女 12 名)。平均年齢 13.2歳（10-18歳）、平均無投薬期間 19 ヶ 月。 $\beta 2$ 刺激薬（サルプタノール）吸入前 後のフローボリュームカーブを測定し、閉 塞の指標として、中枢気道ではPEF(peak expiratory flow)を、末梢気道ではV50、V25 を用いた。

【結果】 $\beta 2$ 刺激薬吸入前後のフローボ リュームカーブの変化は、PEF、V50、V25 のそれぞれ $20 \%$ 以上改善の有無から、1. 無 変化群 $(n=13) 、 2$. 末梢気道閉塞改善群 $(n=18)$ 、 3. 中枢気道閉塞改善群 $(\mathrm{n}=1)$ 、4. 全般改善群 $(n=3) 、 5$. 分類不能群 $(n=2)$ 、に分類された ( 括弧内は例数)。一方、V50 の\%予測值は $\beta$ 2 刺激薬吸入前では 12 例 $(32.4 \%)$ が $70 \%$ 以下であったが、吸入後では $70 \%$ 以下の数 は7例 $(18.9 \%)$ と約半数に低下した。

【結論】寛解状態にある思春期喘息では、 末梢気道閉塞の残存する例が約 $1 / 3$ に認め られた。これらの気道閉塞は、必ずしも不 可逆的でない可能性が示唆された。 
$\mathrm{O} 27$

\section{気管支喘息児における気道過敏性・肺機 能の経時的変化}

○中村久理子 1)、渡辺美砂 1)、内野由美子 1) 竹内邦子 1)、藤原摩耶 1)、柳川 進 1)

岡本則彦1)、波多野道弘 1 )、安部信行 ${ }^{2)}$

1) 東邦大学 医学部 第一小览科

2) 東邦大学医学部 臨床生理機能検査部

【目的】小児気管支喘息では、思春期に症 状が軽快または寛解すると気道過敏性も次 第に改善が見られる。今回気管支喘息児に おける気道過敏性と肺機能の経時的変化を 重症度・治療薬との関連に注目し検討した。

【方法】1999年 6 月〜 2004年 6 月に気道過 敏性試験を 3 ケ月以上の間隔をあけて複数 回施行した外来通院中の小児気管支喘息患 者 49 症例を対象とした。気道過敏性試験は アストグラフ法で行い、重症度、ロイコト リエン (LT) 受容体拮抗薬、吸入ステロイド との関係を診療記録より後方視的に検討し た。

【結果】初回検査時年齢は平均 8.9 歳、平 均検査間隔は 21 ケ月であった。全例で気道 過敏性を認め、37 例 (76\%) で経時的な改善 を認めた。肺機能検査ではV50で軽度低下 傾向である以外に異常はなく、経時的変化 もみられなかった。LT受容体拮抗薬内服を 経過中に開始した 9 例では気道過敏性の有 意な改善を認め、内服していない7例では 有意な変化は認められなかった。吸入ステ ロイドを経過中に開始した 6 例でも気道過 敏性の有意な改善を認め、使用していない 18 例では有意な変化は認められなかった。

【結論】今回の対象の最終検査平均年齢は 10.6 歳であり、一般的に報告されている気 道過敏性の改善がみられる年齢よりやや低 年齢であったが、LT受容体拮抗薬や吸入ス テロイド剤で治療介入をすることにより気 道過敏性の改善時期がより早くなる可能性 が示唆された。
$\mathrm{O} 28$

\section{発症早期から抗炎症薬による治療を試み た乳児喘息 64 例の予後に関する検討}

\author{
○池田政憲 1)、近藤麻衣子 1)、中村彩 1) \\ 堀川定儀 ${ }^{1)}$ 、吉本順子 ${ }^{1)}$ 、神辺智春 ${ }^{1)}$ \\ 二階堂香織 1 )、荒木 徹 1 )、岡本尚子 2)
}
1) 国立病院機構
2) 井原市民病院
福山医療センター 小児科 小児科

【目的】小児気管支喘息児の約 $60 \%$ は 2 歳 までに発症し, 発症年齢のピークは $1 \sim 2$ 歳 にある. 乳児喘息児に発症早期から抗炎症 薬を使用し積極的に発作ゼロを目指して治 療を試み，その中期的予後を検討した。

【対象と方法】1998年 10月～2000年 9 月 の 2 年間に, 反復する喘鳴を主訴に来院し 他疾患を除外した上で乳児喘息と診断した 63 例に対して, 環境整備を含む喘息指導を 実施し，3〜 5 回の発作反復を確認後, 長期 管理薬による治療を導入した。 2004 年 3 月 における臨床経過を検討した。

【結果】対象となった 63 例 (男:女／41:22) は, 発症月齢 $3-23$ 力月 (平均 13.9 ), 治 療開始月齢 3-24 力月 (平均 18.2), 2 歳時 $\mathrm{IgE} 485.4 \mathrm{IU} / \mathrm{ml}, \mathrm{Dp}$ 陽性例は 2 歳時 $68.3 \%$, 3-4 歳時 $87.3 \%$ (CAP-RAST) であった. 間 歇型 9 , 軽症持続型 31 , 中等症持続型 18 , 重症 持続型 5 例で，治療開始後の有症状率は， 1 年後 $69.8 \%, 2$ 年後 $33.3 \% ， 3$ 年後 $9.5 \%$, 4 年後 $4.8 \%$ で，3例において発作が残存し ていた。間歇型の有症状率は重症持続型に 比し 2 年後に有意に低く, 3 年後では $0 \%$ で あった. 発作消失した 60 例の最終発作月齢 は平均 36.9 力月 $(10-62$ 力月), 治療開始 後発作消失までの期間は平均 18.6 力月で あった。

【考察】3歳までに喘鳴を 1 回以上経験した 児の 6 歳における有症状率は Martinez らに よると $40.8 \%$ であり，早期に抗炎症薬を用 いて，積極的に発作消失を指向して継続的 治療を行うことにより，喘息の重症化防止， 早期 out grow の可能性が高まると考えられ た. 
O29

\section{肺機能からみた小児喘息児のDSCG 吸 入液 early intervention 効果}

○菅野訓子 1,2)、吉原重美 2)、小野三佳 2) 山田裕美 2)、阿部利夫 2)、有阪 治 ${ }^{2)}$ 野田雅行 1 )
$\mathrm{O} 30$

\section{小児気管支喘息における予防的治療の早 期導入の有用性についての検討}

\author{
○松野正知 ${ }^{1)}$ 、伊東道夫 ${ }^{1 ）}$ 、足立雄一 ${ }^{2)}$ \\ 五十嵐隆夫 3 )
}

\section{1)西方病院 小児科 \\ 2) 獨協医科大学 小児科}

【目的】小児気管支喘息は、その病態にア レルギー性炎症が存在し、気道閉塞に基づ く気流制限が生じている。当院では、気道 局所への治療が行いやすい DSCG 吸入液に よる長期治療管理を行ってきた。今回、喘 息患児の肺機能推移において、DSCG 吸入 液の早期治療効果が認められるか調査した。

【方法】6歳までに中等症の小児気管支喘 息と診断され、DSCG 吸入液を吸入治療し 6 歳以降に肺機能検査を施行できた患児 52 例について調査した。肺機能はスパイロ メーターにより年 1 度同時期に測定し、各 種パラメータ推移経過を6歳から 15 歳まで 調査した。別途、外来・入院状況の調査も 行なった。

【結果】喘息発症時期加ら DSCG 吸入開始 までの期間が 2 年以内の早期治療群は、 2 年 超の対照群に比べFEV1\%、MMF、PEF、V75、 V50、V25 は有意に改善し、DSCG 吸入液に よる早期治療効果の存在がうかがわれた。 特にV25における改善が早期治療群で著し く、末梢気道での気流制限における効果の 高さが認められた。また、外来回数、入院 日数でも早期治療群での改善が顕著に認め られた。以上より、DSCG 吸入液による早 期治療により肺機能改善が顕著となり、喘 息症状の長期治療管理をより効果的とする ことを示唆するものであった。
1) 新潟県立吉田病院 小児科
2) 富山医科薬科大学 医学部 小児科
3)いからし小児科アレルギークリニック

【目的】小児気管支喘息において，予防的 治療の早期導入の有用性を, 中長期予後や 気道過敏性の推移の面から検討した。

【対象および方法】対象は，12～15才およ び16〜19才に気道過敏性試験をそれぞれ 1 回以上施行した気管支喘息患者 203 例（男 136 例，女 67 例）である。この内，発症か ら 1 年以内に予防的治療（DSCG 吸入, 経 口抗アレルギー薬，吸入ステロイド薬のい ずれか）を開始した 77 例（男 53 例，女 24 例）を早期群，発症 1 年以降に開始した 126 例（男 83 例，女 43 例）を後期群として比 較検討した。発作状況は問診および喘息経 過表で確認し， 2 年以上発作なく経過して 治療中止し, 以後も無発作の状態を維持し ているものを寛解，無発作期間が 2 年に満 たない，または，予防的治療を継続してい る場合を非寛解とした。気道過敏性はアス トグラフを用いて測定し，Dminで評価した。 【結果】初発時重症度は2群間で有意差を 認めなかった（Fisherの直接法）が，最終 検査時での寛解率は早期群で有意に高かっ た（早期群 $76.6 \%$, 後期群 42.9\% ; $<0.001$, Fisher の直接法)。また, 全経過を通して単 一の予防的治療で症状をコントロールし得 た症例の比率は, 早期群で有意に高かった

(早期群 $66.2 \%$, 後期群 $42.1 \%$; p $<0.001$, Fisher の直接法)。気道過敏性（Dmin）は, 早期群において $12 \sim 17$ 歳の各年齢層で有 意に高值をとっていた。以上により，小児 気管支喘息において，予防的治療の早期導 入の有用性が示唆された。 
O31

\section{小児気管支喘息患児における検査結果か らみた吸入ステロイド薬による治療効果}

○滝有希子 1)、井上直之 ${ }^{1)}$ 、永山麻紀子 2) 大場邦弘 1)、大鶴麻里子 1)、松本居子 2) 太田久朗 1)、小池林太郎1)、石川尉子 1) 石垣信男 2)

1) 杏林大学 医学部 小坚科

2)稲城市立病院

【目的】我々の施設において吸入ステロイ ド薬はRTC、経口抗アレルギー薬あるいは DSCGにより治療を開始し効果不十分の場 合に併用している。今回、気管支喘息の治 療目的で通院している患児を対象に吸入ス テロイド薬使用の有無で分類し、その治療 効果を検查結果で比較検討したので報告す る。

【対象・方法】対象は杏林大学医学部小児 科ならびに稲城市立病院小児科のアレルギ 一外来を定期的に受診している気管支喘息 患児 282 名 (男児 183 名、女児99名)。対象 者を吸入ステロイド薬併用の有無で分類し 治療開始前と 1 年後の好酸球数、血清 ECP 值、IgE值、加えて測定可能であった児に 対し呼吸機能、血清 tryptase 值の測定も行 い比較検討した。

【結果・考案】対象者中吸入ステロイド薬 を使用していた患児は96名（男児52名、 女児 44 名） $34 \%$ であった。治療前と 1 年後 の各検查結果では血清ECP值、血清tryptase 值、FEV $1.0 \%$ よび\%v50においてはステロイ ド群、非ステロイド群ともに 1 年後が有意 に改善していた。また各検查值の差（治療 開始前測定値 -1 年後測定值）をもとめ、 2 群を比較したところ血清 ECP 值、血清 tryptase值でステロイド群が有意に高值を とっていた。以上より経ロ抗アレルギー薬、 DSCGおよび吸入ステロイド薬には好酸球 性炎症ならびに肥満細胞の脱顆粒を抑制す る効果を認め、特に吸入ステロイド薬を併 用することでその効果が強くなることが示 唆された。
O32

\section{小児喘息におけるフルチカゾン (FP) の 喘息エピソード調査}

○勝呂 宏 ${ }^{1)}$ 、永倉俊和 ${ }^{2)}$ 、森田 寛 ${ }^{3)}$ 宮川武彦 4)、久保 裕 5)、宮武明彦6) 宮本昭正 ${ }^{7)}$

1)すぐろこどもクリニック、2)用賀アレルギーク リニック、3)お茶の水女子大学保健管理センター 4) 宮川医院、5) 久保クリニック、6)宮武内科

7）日本臨床アレルギー研究所

【目的】小児喘息患者におけるFPの有益性 を検討する。

【方法】過去 6 ケ月間にステロイドを継続 使用していない患者を対象に FP投与前後 の 6 ケ月間に起きた喘息エピソードを調查 し、このうち小児喘息患者について解析し た。

【成績】 FP投与前後の検討症例は 69 例で、 $5 \sim 9$ 歳が $60 \%$ を占め、FPの投与量は 100 〜200 $\mu \mathrm{g} /$ 日が大部分であった。喘息エピ ソードを経験した割合はFP投与前 $81 \%$ から 投与後 $25 \%$ と有意な減少を示し、各エピ ソード別でも入院を経験した割合は $12 \%$ から $0 \%$ 、救急治療室は 35\%から 1\%、予定 外受診は $67 \%$ から 17\%、休みは $72 \%$ から 16\%に減少した。また、投与前の喘息治療 薬、重症度の種類にかかわらず、喘息エピ ソードが劇的な減少を示した。副作用発現 率は1例もみられなかった。

【結論】FPは吸入ステロイド以外の喘息薬 の治療中に起こる喘息エピソードを減少さ せ、小児喘息患者の QOL を大きく向上させ 得る薬剤であることが確認された。 
$\mathrm{O} 33$

\section{小児患者に対するフルチカゾン(FP)の 喘息エピソードに関する医療経済的な検 討}

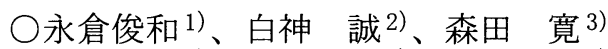
宮川武彦4)、勝呂 宏5)、久保 裕 ${ }^{6)}$ 宮武明彦7)、宮本昭正 ${ }^{8)}$

1)用賀アレルギークリニック、2) 日本大学 薬学部 薬 事管理学研究室、3)お茶の水女子大学 保健管理セン ター、4)宮川医院、5)すぐろこどもクリニック、6)久保 クリニック、7)宮武内科、8）日本臨床アレルギ一研究所

【目的】小児患者に対する FPの有益性を喘 息エピソードに関して医療経済的視点から 検討する。

【方法】6 ケ月以上 ICS 以外の薬物療法が行 われた喘息患者 $(2 \sim 14$ 歳 $)$ に対して、FP投 与前後の各 6 ヶ月間に起きた喘息エピソー ド(入院、救急受診、予定外受診)を金銭価 值に置き換えて、医療経済的な検討を 83 例 で行った。

【結果】喘息エピソード関連諸費用につい て、使用前に比べてFPによる使用後で有意 $(\mathrm{p}<0.001)$ な費用節減 $(80 \sim 100 \%$ 減) が認 められた。また、FPの追加使用により薬剂 費用全体では増分費用が認められたものの、 喘息エピソード関連費用の節減から、医療 費全体では有意 $(\mathrm{p}<0.001)$ な費用節減 $($ 約 $74 \%$ 減)が認められた。さらに、FPの使用 により経口剤の多剂併用をする意義が低い ことが示唆された。

【結論】小児患者においてFPの喘息治療へ の導入は、喘息エピソードの改善に加え、 医療費の面からも重要なアウトカムが期待 できると考えられた。
O34

\section{重症喘息の乳幼児におけるHFA-BDPの 効果一2例の使用経験から一}

\author{
○板澤寿子 1)、足立陽子 1)、中林玄一1) \\ 淵沢童也 1)、足立雄一1)、村上巧啓2 \\ 宮脇利男1)
}
1) 富山医科薬科大学 医学部 小巟科
2) 富山赤十字病院 小児科

【はじめに】代替フロン使用ベクロメタゾ ン (HFA-BDP) は、末梢気道への到達率が 高いことが特徴であるが、本邦では小児の 使用経験が少ない。今回、重症喘息乳幼児 2 例に導入を試みた。

【症例 1】1歳 2 ケ月の女児。在胎 30 週、 $894 \mathrm{~g}$ で出生し、20日間の人工呼吸管理を要 した。月齢 3 より喘鳴を伴う呼吸困難を繰 り返し、家族歷と $\beta$ 刺激薬吸入一の反応性 により喘息と診断。月齢4からフルチカゾ ン（HFA-FP、200 $\mu \mathrm{g} /$ 日）を開始したが、 月齢 6 には人工呼吸管理を要する大発作を 起こした。HFA-BDP $(200 \mu \mathrm{g} /$ 日) に変更

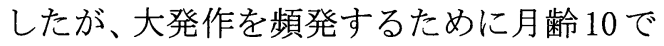
$400 \mu \mathrm{g} /$ 日に增量。その後は発作程度と頻 度が軽減し、200 $\mu \mathrm{g} /$ 日でコントロールさ れている。

【症例2】月齢 8 で発症の 3 歳男児。1 1 歳半 でCFC-BDP $(100 \mu \mathrm{g} /$ 日) を開始。改善が 得られずHFA-FP $(100 \mu \mathrm{g} /$ 日) に変更。 さらに増量 $(200 \mu \mathrm{g} /$ 日) やスペーサーの 変更を行ったが大発作を頻発。2歳 4 ケ月時 にHFA-BDP $(200 \mu \mathrm{g} /$ 日) に変更後はコン トロール良好となっている。

【考案】HFA-BDPは重症喘息の乳幼児にお いても有効である。しかし、投与量や投与 方法に関しては今後の検討課題と考える。 
O35

\section{フルチカゾン大量吸入によって完全に副 腎皮質機能抑制をきたしたと考えられる 1 症例}

○亀田 誠、高松 勇、吉田之範 西川嘉英、土居 悟

大阪府立呼吸器・アレルギー医療センター 小児 科

吸入ステロイド薬 (ICS) は気管支喘息の 予防薬として確立され、全身性副作用は内 服ステロイド薬(PD) と比較して極めて軽 微なものと考えられていた。しかしTodd ら の英国における ICS と副腎不全に関する調 査 (Arch Dis Child 2002;87: 457-61) は、特に フルチカゾン $(\mathrm{FP})$ 大量投与でその可能性が 著しく高いことを示した。今回FP大量投与 によって完全に副腎抑制をきたしたと考え られる症例を経験した。PDを併用していた ためか症状はないがFPに関して注意喚起 を促す症例と考え報告する。

【症例】9歳男児 1 歳 2 ケ月初発。挿管歴 2 回で 2 歳 1 ケ月に当科転院しベクロメサゾ ン (BDP) $1200 \mathrm{mcg}$ を含む治療で退院。一時期 安定したが 3 歳以降増悪し再三入院を要し、 ステロイド全身投与を必要とした。呼吸機 能も不安定で 6 歳 10 ケ月に再度長期入院、 BDP1200mcg でコントロールできずFP(ロ 夕 $800 \mathrm{mcg}$ に変更。更に PD 隔日投与を必要 とし $5 \mathrm{mg}$ 隔日で退院。

【副腎皮質機能】6歳 8 ケ月時 BDP1200mcg での改良 Rapid ACTHテスト (mRA) はコル チゾール(Cor)が前值から順に 8.4, 22.1, $28.7,33.0(\mathrm{mcg} / \mathrm{dl})$ 。 FP開始 5 ヶ月 $(\mathrm{PD}$ は $30 \mathrm{mg} /$ 日から減量し $7.5 \mathrm{mg}$ 隔日)では前值か ら 3.0, 9.1, 9.3, 8.0。開始 7 ヶ月 (PD5mg 隔 日）には $1.6,11.2,15.4,18.2$ でむしろ改善。 7 ケ月後 PD $2.5 \mathrm{mg}$ に減量。その後 PD 非内服 日の午後の Cor が 3 回続けて 0.1 となり PD を $1 \mathrm{mg}$ まで減量しても不変。減量 2 ケ月後 の mRA は順に $0.1,0.7,0.5,0.2$ 。現在 FPを $400 \mathrm{mcg}$ まで漸減し慎重に経過を追ってい る。

\section{O36}

\section{乳幼児気管支喘息における Fluticasone Propionate 吸入の効果と成長抑制に関す る検討}

○阿部法子、勝沼俊雄、赤司賢一 柴田 淳、衛藤義勝

東京慈恵会医科大学付属病院 小児科

【研究背景】小児気管支喘息の病態におい ても、慢性気道炎症の関与が示唆されるこ とから、吸入ステロイド剤による長期喘息 管理が重視されてきた。2〜 5 歳の喘息長期 管理プランにおいては、JPGL2002、 GINA2003 ともにステップ2(軽症持続型)か らの使用が考慮・推奨されている。今回我々 は、乳幼览気管支喘息に対する fluticasone propionate（FP）の効果と成長への影響を 後方視野的に検討した。

【対象】 FP開始時年齢が 6 歳未満で、以降 継続中の喘息児を対象とした（22名、開始 時平均年齢 4.6 歳)。使用量は $50 \sim 200 \mu \mathrm{g} /$ 日であった。

【方法】身長の変遷を、診療録、母子手帳、通 園先の身体測定記録より抽出し検討した。 臨床症状の変化は喘息日記より解析した。 身長・成長率 SD スコアの変化を、性、年齢、 重症度、使用量、使用期間別に検討した。

【結果】効果に関しては、FP開始後全例で 症状の改善を認めた。FP前後の身長スコア には有意な変動を認めなかったが、成長率 スコアは、女児において有意な減少を認め た。抑制に関しFPによる用量依存関係を認 めなかった。また 12 ケ月以上の使用期間で 有意なスコアの減少を認めなかった。

【まとめ】乳幼児気管支喘息においてFPは 明らかな改善効果を示した。身長スコアに 有意な変動を認めなかったが、成長率スコ アは女児において減少傾向を示した。今後 さらに詳細な解析を進める予定である。 


\section{O37}

\section{細気管支炎症状を呈した乳児に対する pranlukastの効果}

○井口正道 ${ }^{1)}$ 、小俣貴嗣1)、杉原 桂 ${ }^{1)}$

田知本寛 ${ }^{1)}$ 、宿谷明紀 ${ }^{1)}$ 、海老澤元宏 ${ }^{2)}$

1）(独）国立病院機構 相模原病院小览科

2) 臨床研究センターアレルギー性疾患研究部

【背景】Montelukast が細気管支炎の長期予 後の改善に有効であるとの報告がある. 我々はPranlukast の細気管支炎に対する短 期・中期的効果に関して検討を加えた。

【方法】平成 15 年 12 月から平成 16 年 4 月 までに（独）国立病院機構相模原病院小児 科にて入院加療した細気管支炎症状を呈し 呼吸障害を伴った乳児に対して pranlukast 投与群と非投与群に分けその効果を入院中 の治療内容・症状、さらに発症から 4 週間 までを喘息日記を用いて症状を経過観察し た.

【結果】対象は 14 例（男女比 $11: 3$, 投与 群：非投与群 $7: 7$, 平均月齢 8.6 か月） で、 うち 9 例で発症後 4 週間フォローし得た。 RSV迅速検査にて陽性を示したのは7例(投 与群 : 非投与群 $3: 4$ ) であり、抗体価 (補 体結合反応)での上昇を認めたのは 1 例で あった. 入院期間、酸素投与期間は非投与 群vs投与群がそれぞれ $10.7 \pm 4.2$ 日間vs9.6 \pm 5.5 日間、 $2.7 \pm 4.1$ 日間 vs $3.1 \pm 7.1$ 日間 であり有意差は認めなかったが、退院後喘 鳴の出現日数は $5.6 \pm 44.3$ 日 vs $0.5 \pm 1.5$ 日 であり、投与群に短い傾向を認めた。

【考察】急性期の症状改善には効果がみら れなかったが、退院後の喘鳴のコントロー ルに関して有効性がある可能性と考えられ た. 今後さらに症例を積み重ね検討する価 值はあると思われた。
O38

\section{小児気管支喘息急性増悪に対する Methylxanthineの効果 ; $81 \mathrm{mKr}$ 換気 シンチグラフによる検討}

○赤司賢一 1$)$ 、勝沼俊雄 ${ }^{1)}$ 、衛藤義勝 ${ }^{1)}$ 森 豊2)

【背景】喘息の増悪に対する Methylxanthine (以下 MeX と略) の使用に関しては賛否両 論がある。欧米の報告は主にMexの副作用 を強調し，その有効性を疑問視するものが 多数を占める. しかしそれらの研究デザイ ンは，重症発作例に対し頻回の $\beta_{2}$ 刺激薬吸 入とステロイド全身投与の後に検討を行 なっている。実際に, GINA では急性増悪時 の入院治療として第 5 選択薬以下の扱いで ある.今回我々は喘息の軽度増悪時（増悪 早期）における $\mathrm{MeX}$ の効果を検討した。

【方法】喘息増悪が認められた小児 20 人に 対し対照として生理食塩水を静注した 30 分後, $\mathrm{MeX} 5 \mathrm{mg} / \mathrm{kg}$ を 5 分以上かけて静注し た. $81 \mathrm{mKr}$ 換気シンチグラフと呼吸機能測 定を経時的に施行した。副作用は質問紙で 確認した。

【結果】 $81 \mathrm{mKr}$ 換気シンチグラフでは，対 照に比しMeXでは 54.9\%の改善を示した $(\mathrm{p}$ <0.0001). また末梢および中枢気道ともに 肺欠損領域の改善を認めた $(\mathrm{p}<0.0001)$. こ れらの結果は, PEFR(p < 0.05), FEV1.0(p $<0.01), \mathrm{V} 25(\mathrm{p}<0.001)$ における肺機能の改 善と一致した。全被験者において有意な副 作用は認められなかった。

【結論】MeXは喘息の増悪が軽度（早期） な段階においては，中枢および末梢気道と もに，換気障害・不均衡を改善させる有用 な気管支拡張薬であるといえる。 
O39

\section{テオフィリン内服中に生じた痙攣重積症 例の検討}

○小高 学、森田清子、絹巻暁子

黒澤照喜、和気彰子、柳原知子

榊原裕史、松岡典子、小鍛治雅之

寺川敏郎、遠藤泰弘、横路征太郎

東京都立府中病院 小巟科

テオフィリン製剤は、気管支拡張剂とし て喘息治療などに広く用いられているが、 副作用としてのけいれん発作が知られてい る。今回都立府中病院小児科において経験 した、テオフィリン内服中に生じた痙攣重 積症例について、臨床的ならびに統計的検 討を行ったので報告する。1993 年 1 月から 2004 年 4 月までに痤攣を主訴として救急受 診した患児の総数は、4455例であった。痤 攣重積症は 309 例、その内、テオフィリン 内服中の症例は 24 例であった。24例の内訳 は、年齢 : 2 歳以下が、18例と低年齢に多 く、血中濃度:明らかな中毒域 $(54.7 \mu \mathrm{g} / \mathrm{ml})$ は1例、20 $\mu \mathrm{g} / \mathrm{ml}$ 以下が、19例であった。 当院の統計からはテオフィリン内服中の痤 攣発作は重積症となりやすいことが推測さ れた。また、重積症の中でも最重症である 気管内挿管となる率は、テオフィリン内服 群の方が非内服群よりも有意に高いことが 示された。以上より、痙攣の既往のある児 には、テオフィリン投与は控えるべきであ ると考える。

\section{$\mathrm{O} 40$}

\section{小児気管支喘息発作における $\beta 2$ 刺激薬 反復吸入についての検討}

○道海秀則、岸田 勝、中園宏紀 足立 玲、中里純子、鈴木五男 四宮範明、青木継稔

東邦大学医学部附属大橋病院第二小肾科

わが国においては小児気管支喘息発作時 の「 $\beta 2$ 刺激薬の反復吸入」についての臨 床的検討は少ない。今回、小児気管支喘息 児を対象に喘息発作で外来を受診した患児 を対象に $\beta$ 刺激薬の反復吸入の有用性につ いて検討した。対象は喘息発作を主訴に来 院した 8 時間前以降拡張薬の使用がなかつ た 1 歳から 15 歳 (平均 5.5 歳) の患児 9 名 である。方法は年齢および体重に関係なく 初回吸入、生理食塩水 $2 \mathrm{ml}+$ ベネトリン $0.3 \mathrm{ml}$ (平均 $0.0136 \mathrm{ml} / \mathrm{kg}$ ) で施行、追加吸 入が必要と判断した症例 (酸素飽和度 $\mathrm{SpO} 2$ が $97 \%$ 以上にならないまたは後述する喘鳴 の程度のスコアが 2 未満にならない）につ いて 15 分間隔で同様の吸入を最大で合計 3 回まで施行した。その間、酸素飽和度 (SpO2)、呼吸数、心拍数、喘鳴の程度 (スコア $4=$ 呼吸音の減弱を伴う両相の喘 鳴、スコア $3=$ 両相での喘名、スコア $2=$ 呼気時喘鳴、スコア $1=$ 強制呼気時喘鳴、 スコア $0=$ 喘鳴ほぼなし）を観察した。結 果、全症例数 9 、吸入施行回数 1 回が 1 例、 2 回が 6 例、3 回が 2 例であった。吸入前平 均 $\mathrm{SpO} 2: 93 \%$ 、呼吸数: 31 回/分、喘鳴の程 度: スコア 3 、反復吸入後平均 $\mathrm{SpO} 2: 97 \%$ 、 平均呼吸数:23.5回/分、喘鳴の程度:スコア 0.7 と全例で呼吸状態の改善が見られた.ま た吸入前平均心拍数 114 、反復吸入後心拍 数 113.6 と心悸六進は見られなかった。 
$\mathrm{O} 41$

\section{マスクを用いたネブライザー吸入におけ る「鼻からの吸入」と「口からの吸入」 の比較}

○橋本亜衣子 11 、西川実希子1)

黒田典子 1)、田中英行 ${ }^{2)}$ 、南部光彦 3 )

\section{1) 天理よろづ相談所病院薬剤部 \\ 2) 天理よろづ相談所病院看護部 \\ 3) 天理よろづ相談所病院小児アレルギーセンター}

【目的】クロモグリク酸ナトリウム (DSCG) 吸入療法は、小児気管支喘息のコントロー ラーとして一般的に施行されているが、マ スクを用いたネブライザー吸入に際し、鼻 と口のどちらから吸い込んでいるか、一定 していない。今回、鼻から吸入した場合と 口から吸入した場合のどちらが吸入効率が よいか比較を行い、吸入療法の問題点を探 り出すとともに、よりよい吸入方法につい て検討する。

【方法】吸入後、肺内に沈着したDSCGは 血中に吸収され、約 $40 \%$ が未変化体のまま 尿中に排泄される。その $90 \%$ 以上が 4 時間以 内に排泄されることから、吸入後 4 時間以 上蓄尿した尿中のDSCG 排泄率を測定する ことによって、その吸入効率を評価した。

被験者は健康な成人で、排尿後 DSCG20mg をネブライザー(オムロンNE-U22)を用い て連続噴霧にて、鼻からと、口からの 2 通 りの吸入を行い、4 時間以上経ってから採 尿し、尿量を測定した。尿中のDSCG 濃度 は高速液体クロマトグラフィーを用いて測 定した。

【結果と考察】DSCG 尿中排泄率を測定し た結果、3名の被験者のうち 2 名は口からの 吸入の方が、1名は鼻からの吸入の方が尿 中排泄率が高かった。口からの方が吸入効 率がよかった被験者は吸入中、努力性呼吸 を行ったのに対し、鼻からの方が吸入効率 がよかった被験者は安静呼吸であった。鼻 からと口からの吸入効率には呼吸の仕方も 影響していると考えられ、吸気の深さによ る違いについても検討したい。
$\mathrm{O} 42$

\section{睡眠時吸入療法におけるポストリフト法 の有用性について}

○南部光彦 1)、田中英行 2$) 、$ 橋本亜衣子 3$)$ 西川実希子3)、黒田典子3)
1)天理よろづ相談所病院 小児アレルギーセン ター

2)天理よろづ相談所病院 看護部

3) 天理よろづ相談所病院 薬剂部

【目的】これまで我々は、睡眠中に吸入を 行っている喘息児がいること、睡眠中の吸 入効率は不良であること、また睡眠中の吸 入に呼気時胸郭圧迫法 (スクイージング) は無効であることを報告してきた。今回は、 吸気量を増やすことを目的とする呼吸理学 療法の一つであるポストリフト法（リフ ティングともいう）が、睡眠時の吸入に有 効であるかどうかを検討する。

【対象と方法】対象は喘息児 3 人。吸入効 率は、DSCG $20 \mathrm{mg}$ 吸入後の DSCG 尿中排泄 量を用いて評価した。DSCG吸入は、オム ロンNE-U22 を用いて連続噴霧にて行った。 仰臥位での睡眠中に、胸郭下部から腰部に あてがったタオルの両端を、吸気に合わせ て上に持ち上げるようにして、リフティン グを行った。ポストリフトの有無で、DSCG 尿中排泄量を比較した。

【結果】DSCG尿中排泄量（ $\mu \mathrm{g} ）$ は、ポス トリフトなし/ありで、7歳男児 1056/331、 10 歳女児 $384 / 899 、 12$ 歳男児663/777であっ た。有効であった 10 歳女览では、熟睡して いて深い吸気ができ、呼気の音も非常によ く聞こえた。12歳男児では、体重が重くて 持ち上げることができず、また途中で覚醒 した。7歳男児では、ポストリフトを施行 することによって寝返りの回数が増えたた め、吸入効率はむしろ悪化した。

【考察】症例によっては、睡眠時吸入にポ ストリフトが有効であった。症例数を増や して検討したい。 
$\mathrm{O} 43$

\section{若年性サルコイドーシス（EOS）と CARD15 (NOD2) 遺伝子異常との関係 〜本邦での11例の検討〜}

$\bigcirc$ 岡藤郁夫 ${ }^{1 ）}$ 、西小森隆太 ${ }^{1)}$ 、吉岡孝和 ${ }^{1)}$ 齋藤 潤 1)、楠隆1)、平家俊男 1) 中畑龍俊 1)、萬木 章 2)、堤 裕幸3) 宇加江進 3)、藤原幾磨 4 )、櫝井嘉彦5) 浅田和豊 6 )

1) 京都大学大学院 発達小児科学、2) 岡山大学医

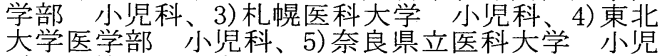
科、6)徳山中央病院 小児科

若年性サルコイドーシス (EOS) は、4歳以 前に発症し、ブドウ膜炎・発疹・関節炎を 3 主徵とする稀な疾患である。近年、EOS と病像が酷似しているが、家族集積性があ り、常染色体優性遺伝形式をとる Blau 症候 群(BS)の責任遺伝子がCARD15(NOD2)であ り、NF- $\kappa$ B が恒常的に活性化しているこ とが報告され、CARD15(NOD2) 遺伝子異常 とEOSとの関連が議論されている。今回、 我々は本邦でのEOS11例について CARD15(NOD2)遺伝子全exonをシークエ ンスした。4例にBSで報告されている $\mathrm{C} 1000 \mathrm{~T}(\mathrm{R} 334 \mathrm{~W})$ 変異が、5例に新規の遺伝 子変異 C1146G(D382E)、A1487T(H496L)、 T1538C(M513T)、A1813C(T605P)、C2010A (N670K)が明らかになった。CARD15(NOD2) 遺伝子にはアミノ酸異常を伴う Single Nucleotide Polymorphism が多数存在し、その 解釈には注意を要する。そのため、健康日 本人 100 人についてもシークエンスしたが、 同様の遺伝子異常を示したケースは認めら れなかった。また、NF- $\kappa$ B の basal activity については、変異体全てでBS と同様に恒常 的な上昇を認めた。以上より、EOS と BSが ともにCARD15(NOD2) 遺伝子異常を示し、 恒常的な $\mathrm{NF}-\kappa \mathrm{B}$ 活性上昇を示しており、 両疾患が共通の病因機序を持つことが明ら かとなった。今後、症例を蓄積し、遺伝子 異常と表現型の関係を含めたさらなる検討 を加えていく予定である。（共同研究者: 金 澤伸雄、神戸直智 (京都大学大学院 皮膚 科学))
$\mathrm{O} 44$

\section{選択的 $\lg$ A 欠損症の病態解析}
○堀越啓子、金子英雄、金栄 川本典生、馬㴊裕子、浅野 勉 深尾敏幸、近藤直実

岐阜大学大学院医学研究科小児病態学

【目的】選択的IgA 欠損症の病態について はいまだ明らかではない。 IgA 欠損の病態 を明らかにするため、患者 B 細胞のクラス スイッチの段階について検討した。

【方法】末梢血単核球(PBMCs)を分離し、無 刺激またはTGF $\beta$ 1+PMAにて 24 時間培養 を行つた。germline transcripts, mature transcriptsをRT-PCRにて解析した。IgAへ のクラススイッチを反映する circular DNA 側の転写 (circle transcripts)を測定した。 IgA1, IgA2 の発現を特異的に検出するため に、相同性の低い配列にプライマーを設定 しPCRを行った。

【結果】患者 $\mathrm{B}$ 細胞ではクラススイッチに 先立って発現する $\mathrm{C} \alpha$ germline transcripts は無刺激で低下しており、TGF- $\beta 1$ と PMA 刺激によりコントロールとほぼ同程度に誘 導された。circle transcripts は患児で無刺激 では全く発現が認められなかったが TGF$\beta 1$ とPMA刺激により誘導された。mature transcriptsは無刺激で発現が低下していた が、TGF- $\beta 1$ とPMA刺激により発現が誘 導される症例もみられた。

【考察】選択的 IgA 欠損症のある症例では 刺激により正常と同様に、 germline transcripts, mature transcripts を発現した。 これらの症例ではクラススイッチに関する B 細胞機能は正常と考えられた。さらにク ラススイッチの場に移動するのに重要なケ モカイン、ケモカインリセプターについて 検討中である。 
$\mathrm{O} 45$

\section{ネフローゼ症候群を合併した木村氏病の 一例}

○今井一徳、持田圭仁、高崎靖子

斉藤 朗、河辺義和

蒲郡市民病院 小児科

木村氏病は全身の皮下軟部組織、リンパ 節に無痛性の腫瘤を形成し、慢性的な経過 をたどる比較的稀な良性疾患である。今回 我々は耳後部の腫瘤を主訴に受診しステロ イド治療を開始したが、経過観察中にネフ ローゼ症候群を合併した 1 例を経験したの で報告する。症例は 12 才男児。約 2 年前か ら左耳後部の腫脹ありその後徐々に増大。 腫瘤は左耳後部に直径約 4 センチ大、表面 はソフトで圧痛などはなかった。一般検査 では生化学、検尿に異常なく CRP 上昇もな し。白血球数は 8800 で血液像では好酸球が $40 \%$ を占め、IgE も $2417 \mathrm{IU} / 1$ と高值を示し た。生検では好酸球のびまん性浸潤を認め、 以上の結果から木村氏病と診断してステロ イド投与を開始した。プレドニン内服後腫 瘤は著明に縮小し、その後薬を漸減したが 腫瘤は更に縮小傾向を示した。治療 3 ヶ月 後、白血球 11000 で好酸球 $2.6 \%$ 、 IgE 1248 IU/1 と改善していたため、プレドニンを中 止したところまた腫瘤は増大した。その頃 から蛋白尿が出現し低蛋白血症なども認め られネフローゼ症候群の合併と診断した。 木村氏病の病因はいまだ不明で再発率も非 常に高く、その治療法はいまだ確立されて いない。ステロイド療法は有効とはされて いるが、ステロイド剤単独では抑えきれず、 抗アレルギー剂との併用が有効との報告も ある。好酸球の局所浸潤が何らかの影響を 与えている事は明らかと思われ、ステロイ ド治療に加え抗アレルギー剤の併用を開始 したので経過を報告する。
$\mathrm{O} 46$

\section{新生児期消化器症状にて発症し、解除後 便秘を呈した牛乳アレルギーの一例}

\author{
○鈴木修一1）、沼田朋子 2)、冨板美奈子 1) \\ 井上祐三朗 1 )、下条直樹 1 )、河野陽一 1)
}

1) 千葉大学大学院 医学研究院 小児病態学

2) 千葉市立青葉病院

【症例】5歳女児。両親共にアレルギー疾 患なし。35週6日2262g 帝王切開にて二卵性 双生児第二子として出生した。人工乳哺乳 開始し日齢 1 腹部膨満、その後血便が出現 L、日齢 9 総 IgE 值 $23 \mathrm{IU} / \mathrm{ml}$, 牛乳 RAST 陽性 にて牛乳アレルギーと診断された。カゼイ ン分解乳を開始し症状は改善した。5か月 時牛乳 RAST 陰性化し、2 歳時当科にて牛乳 経口負荷試験施行し陰性と判定された。そ の後乳製品は連日摂取できるようになった が、ピコスルファートナトリウム不応の便 秘症となった。また、咳き込み発作主体の 気管支喘息およびアレルギー性鼻炎も発症 した。更に入浴後に膨疹・紅斑が背部中心 に出現するようになった。牛乳除去とした ところ排便はほぼ毎日となり皮疹も軽快し た。牛乳摂取を再開すると便秘と皮疹が出 現した。最近の総 $\mathrm{IgE}$ 值は $<18 \mathrm{IU} / \mathrm{ml}$, 牛乳 RAST 陰性であった。

【考察】便秘の原因としての牛乳アレル ギーは、頻度は少ないものの览および親の 負担が大きく、小児便秘症における鑑別診 断上重要である。海外において報告が蓄積 されてきたが、機序は不明な点が多く intolerance との差異も明確ではない。本症 例は発症時牛乳 RAST 陽性であり解除後皮 疹も伴っていることから、何らかの免疫学 的機序を介しているものと考えられる。便 粘液中好酸球、パッチテストや牛乳刺激に よるリンパ球サイトカイン産生なども検討 して報告する。 
$\mathrm{O} 47$

\section{生直後に一過性に発症した好酸球性大腸 炎の3例}

○青柳 陽、大塚宜一、工藤孝広 和田万里子、藤井 徹、永田 智 山城雄一郎
$\mathrm{O} 48$

\section{著明な腸管浮腫を来たした milk induced enterocolitis syndrome $の 1$ 例}

○谷本敬美、滝沢琢己、荒川浩一 水野隆久、望月博之、徳山研一 森川昭廣
【背景】新生児期に、一過性に血便を呈す る症例のほとんどが原因不明である。経腸 栄養開始前より血便を呈した 3 例を経験し たので報告する。

【症例】症例 1 : 日齢 0 女览。在胎 35 週 0 日、 $2,512 \mathrm{~g} 、$ Ap $9 / 10$ にて出生。生後数分よ り血便が出現。日齢 2 白血球数 $\left(39,000 / \mathrm{mm}^{3}\right)$ および好酸球数 $\left(2886 / \mathrm{mm}^{3}\right)$ が高值であったが、その他血液検査に異常 を認めなかった。血便は日齢 3 まで認めた。 症例 2 : 日齢 2 女児。在胎 34 週 4 日、 $2,140 \mathrm{~g}$ 、 Ap 6/9 にて出生。生後 30 分より血便が出現 し、絶食、ビタミン $\mathrm{K}$ 投与後も持続した。 白血 球数 は $44,000 / \mathrm{mm}^{3}$ (好 酸 球 数 $\left.6038 / \mathrm{mm}^{3}\right)$ 。日齢 7 に大腸内視鏡検査を施行 し、粘膜の浮腫、点状発赤、出血を認め、 組織検査では粘膜内に瀰漫性の好酸球浸潤 を認めた。血便は日齢 8 に消失した。症例 3 : 日齢 7 男児。在胎 37 週 1 日、 $2,564 \mathrm{~g} 、 A p$ $8 / 9$ にて出生。生後 5 分より血便が出現。白 血球数 $17,000 / \mathrm{mm}^{3}$ (好酸球数 $1955 / \mathrm{mm}^{3}$ )。 大腸内視鏡検査、組織検査で症例 2 と同様 であった。血中ECP值は $123 \mu \mathrm{g} / 1$ (正常 14.7 $\mu \mathrm{g} / 1$ 以下）と高值であった。

【考案】経腸栄養開始前より血便を呈した 3 例の新生児を経験した。末梢血好酸球数、 内視鏡・病理所見ならびにECP值より本病 態には活性化された好酸球が深く関与して いることが示唆された。直腸から S 状結腸 の内視鏡検査は新生児においても比較的安 全で、本病態の診断に有用であった。生後 早期に一過性の血便を呈した児の中に、従 来の疾患概念と異なる一過性の好酸球性大 腸炎様病態が含まれる可能性が示唆された。
群馬大学 大学院 小児生体防御学

症例は 1 歳 7 ケ月の男児。主訴は不明熱、 腹満、体重減少。原因検索のため各種画像 検査を実施。腹部CTでは小腸壁のびまん性 肥厚と腸間膜リンパ節腫脹を、 $\mathrm{Ga}$ シンチで は腹部正中に異常集積を軽度認めた。上部、 下部消化管内視鏡検査では、肉眼的には粘 膜面に明らかな異常はなく組織学的には非 特異的慢性炎症性変化を認めた。更なる原 因検索のため、腹腔鏡下小腸全層生検、リ ンパ節生検を施行し、腸管壁全層の非特異 的炎症像と著明な浮腫および粘膜層の肥厚 を認めた。入院後絶食とし中心静脈栄養と したところ発熱、腹満などの症状に改善が 見られた。成分栄養開始後も症状は安定し ていたが、ヨーグルト摂取 2 時間後に腹痛、 嘔吐、腹満が出現した。食物アレルギーを 疑いチャレンジテストを施行した。小麦や 卵などでは症状は認められなかったが、 ヨーグルト摂取にて上記症状が再現されミ ルクアレルギーが考えられた。牛乳に対す るRAST、特異的 IgG4、皮膚プリックテス 卜は全て陰性であったがリンパ球刺激試験

（LST）は陽性で、摂取後 2 時間で消化器 症状のみ出現していることより milk induced enterocolitis syndrome と診断した。 診断後、乳製品の除去を行ったところ消化 器症状は出現せず体重増加も良好となった。 3 歳 6 力月に乳製品の負荷試験を再検した ところ症状の出現はなく、LST は低下して いた。 
O49

原材料名に表示のなかったアレルゲン混 入によりアナフィラキシー症状を呈した 3 例

○森川みき

$\mathrm{JR}$ 仙台病院 小览科

食物アレルギー児が食品を選ぶ上で、必 要不可欠な原材料名の表示が、不適切で あったためにアナフィラキシー症状が誘発 された 3 例を経験した。症例 $1: 3$ 歳男児、 小麦アレルギー（小麦特異 IgE 抗体クラス 6)。駄菓子の「おこし」を食べて、約 30 分 後に咳、喘鳴あり、その後全身蕁麻疹も出 現し、当科を受診。後日、原材料が表示さ れている「もち米」ではなく「小麦」であっ たことが判明。症例 $2: 3$ 歳男児、牛乳ア レルギー(牛乳特異 $\operatorname{IgE}$ 抗体クラス 4)。チョ コレートを食べて 30 分後に萇麻疹数個出 現、約 1 時間で全身性の蕁麻疹となり、嘔 吐も認め、近医を受診した。後日、チョコ レート、カカオの特異 IgE抗体陰性で、摂 取したチョコレートには、表示には無い牛 乳蛋白が混入していたことが判明。症例 $3: 6$ 歳男児、小麦アレルギー（小麦特異 IgE 抗体クラス 6)。アレルギー用の米パンを食 べて約 1 時間で全身䕒麻疹、喘鳴出現し、 当科を受診した。後日、その米パンには小 麦蛋白が混入していたことが判明。以上 のような原料名表示の不備は、食物アレル ギー児に対して、生命の危険をともなうこ とは言うまでも無く、今後より一層正確な 表示の徹底が望まれる。
O50

\section{食物アレルギー患者がアナフィラキシー を誘発した際の食品形態、販売形態、対 処方法及び食品原材料名等の調査結果に ついて}

○神奈川芳行、今村知明

東京大学 医学部 附属病院 企画経営部 企画 情報運営部

【目的と対象】食物アレルギー患者の行動 実態把握のため、全国的な患者会会員 1510 家族に対して、、食物アレルギ一発症回避の ためのアンケート調査」を実施した。回答 家族数は 878 家族（回収率 $58 \%$ ）、有効回答 患者数は延べ1383名（内、アナフィラキ シ一経験者 402名）であった。

【結果の概要】アナフィラキシーの原因 食品の販売形態では、「容器包装加工食品」、

「店頭販売品」、「レストラン (食堂)」での 食事の順であった。発症場所と原因食品の クロス集計では、「自宅」での「容器包装加 工食品」や「店頭販売品」が最も多く、次 いで、「レストラン(食堂)」での食事、

「ファーストフード」の「店頭販売品」の 順であり、学校給食での発生は多くない。 原因物質では、「乳、卵、小麦」の順である が、「レストラン (食堂)」では「卵」が最 も多かった。「可能性表示」は、原材料に含 む旨の表示と同程度に購入を避ける傾向に あるが、「アレルギー物質が異なるラインで 使用されている旨」の注意喚起等、詳細な 製造状況が記載されている場合には購入を 避ける傾向は少ない。今後、現在表示義務 のない販売形態の食品や場所においても、 何らかの形での情報提供が必要である。 
O51

\section{目黒区立保育園における食物アレルギー 児に対する対応状況について}

○中里純子、岸田 勝、中園宏紀 足立 玲、道海秀則、鈴木五男 四宮範明、青木継稔
$\mathrm{O} 52$

\section{食物アレルギー児におけるトランスアミ ナーゼ高値例の検討}

○下平佳代子、渡辺美砂、橋本卓史 内野由美子、月本一郎
東邦大学 医学部 大橋病院 小巟科

当院の位置する目黒区立保育園における 食物アレルギー児に対する対応状況につい て検討し, 報告する。1. 最近 5 年間の除 去食実施園览数の推移では，平成 11 年度 : 94 名 $(5.1 \%), 12$ 年度 : 95 名 $(4.9 \%), 13$ 年 度：90名 $(4.7 \%), 14$ 年度：109名 $(5.6 \%)$, 15 年度 : 116 名 (5.8\%) で増加傾向にあっ た。2. 最近 5 年間の除去食実施園览数の年 齢分布の平均では，0歳児：14\%，1歳児： 26\%，2歳児：19\%，3歳児：15\%，4歳児： 14\%，5歳児: $12 \%$ で，1歳児がピークで，そ の後漸減するが, 5 歳時においても $12 \%$ の園 児が除去をしていた。2. 最近 5 年間の除 去食物の種類では，約半数の園児が卵，約 $20 \%$ の園児が牛乳, 約 10\%がソバ, 4 〜 $5 \%$ が 大豆や種実（ピーナッツ，ゴマ，くるみ等） であったが，最近の傾向として卵，牛乳は 変わらないもののピーナッツやゴマの増加 およびトマトやキウイ等の野菜や果物も散 見され，ますます除去食物の多様化が伺わ れた。なお，今回の検討は，目黒区健康福 祉部保育課および同区教育委員会学務課の 協力の基に行われた。
東邦大学 医学部 第一小児科

【目的】食物アレルギー児においてトラン スアミナーゼ高値を認める例が散見される ため、トランスアミナーゼ高值例の頻度、 背景について検討した。

【対象と方法】対象は 1994 年 1 月～2004 年 3 月に食物摂取により症状を呈し当院にて 加療した 1 歳未満の児 79 例（男児 46 例、女 児 33 例)。抗アレルギー薬を含む薬剂投与 例、アレルギー以外の基礎疾患を有する例、 明らかな感染のある例は除外。AST ・ALT 高值の基準は 50IU/1 以上とし、診療記録よ り後方視的に検討。

【結果】抗原食物は卵 36 例、ミルク 43 例。 全体の $44.3 \%$ にランスアミナーゼ高值 (高 值群）を認め、抗原別ではミルク $55.8 \%$ $(24 / 43) 、$ 卵 $30.6 \%(11 / 36)$ で、ミルク例 で有意に多かった（ $\mathrm{p}=0.02 ）$ 。また、高值 群は正常群に比し有意に発症年齢が低く、

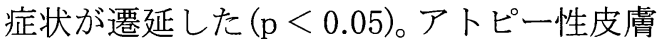
炎合併率、3大アレルギー家族歴、好酸球 数、IgE 值では有意差を認めなかった。高 值群の約半数は 6 ヶ月以内、全例 14 ヶ月以 内にトランスアミナーゼ值は正常化し予後 良好であった。抗アレルギ一剂投与の有無 による改善時期の差は認められなかった。

【考案】肝障害の機序として、腸管を通過 した食物抗原が経門脈的に直接肝細胞を障 害することや、高サイトカイン血症による 肝障害等が推察されたが、今後は胆道系酵 素やサイトカインなどを測定し検討を行う 予定である。 
O53

\section{アトピー性皮膚炎に伴う痒み軽減繊維 DH - 001 の有効性の検討}

○我妻義則 ${ }^{1)}$ 、梅津愛子 2$)$ 、小泉洋子 3 ) 田中真弓 4)、筒井真人 5)、山中 樹 6) 中川秀己 7)、檜垣誠吾 ${ }^{8)}$ 、松田 孝9)

1)わがつまこどもクリニック、2) うめつ小児科、3) 小泉 皮膚科クリニック、4)あけぼの皮フ科、5)つつい皮膚科 クリニック、6)山中たつる小児科、7)東京慈恵会医科大 学 皮膚科学講座、8)大和紡績、9)久光製薬

【背景】金属フタロシアニンで染色加工し た繊維は消臭繊維として、既に義手義足時 の保護材や骨折時のスタンプソックスとし て使用されている。この繊維がアトピー性 皮膚炎の痒みをも軽減させる効果が明らか になった事から、科学技術振興機構の委託 開発事業に選定され、現在「アトピ一性皮 膚炎に伴う痒み軽減䋐維 DH - 001 の有効性 及び安全性の検討」として二重盲検試験が 実施されている。今回、我々はDH-001で 作られた下着上下セットをアトピー性皮膚 炎患児に着用させ、痒み軽減効果を検討す る機会を得たので報告する。

【対象、方法】外来受診している 4 13才 のアトピー性皮膚炎患児 19名 (男児6名、女 児 13 名：平均年齢ほぼ 8 才）を対象とし、 1 週間のウオッシュアウト（保湿剤とロコ イド軟膏のみ使用)を行ない、5 日目から 7 日目 3 日間の平均痒みスコア 2 点以上の患 児に、この下着上下セットを夜間睡眠時に 7 日間着用させ、痒み日誌に痒みスコアを 記載させた。

【結果】19例を観察対象として結果をまと めた。総合評価として著効 6 例、有効 8 例、 やや有効 2 例、不変 3 例で有効以上は $73.7 \%$ であった。金属フタロシアニン加工繊維が アトピー性皮膚炎に伴う痒みを抑制する機 序は不明であるが、この繊維で加工された 下着は痒みを軽減する臨床効果を有する事 が示唆された。以上について述べる。
O54

\section{気管支喘息に合併したアトピー性皮膚炎 に対するプランルカストの臨床効果}

\author{
○竹内三奈 1,2$)$ 、縣 裕篤 ${ }^{1)}$ 、川合紀子 1) \\ 鶴澤正仁 ${ }^{1)}$
}

\begin{abstract}
1) 愛知医科大学 医学部 小坚科
2)藤掛病院 小巟科
\end{abstract}

【目的】気管支喘息にはアトピー性皮膚炎 の合併が多く見られ、小児科医は両者の治 療に携わることになる。抗ロイコトリエン 拮抗薬であるプランルカストは、乳幼児へ の投与も可能であり、気管支喘息の治療薬 として有用であるが、アトピー性皮膚炎に は現在のところ適応がない。そこで、気管 支喘息の治療としてプランルカストを投与 した症例でのアトピー性皮膚炎に対する有 効性を比較検討した。

【対象と方法】平成 12 年 4 月 1 日から平成 16 年 3 月 31 日までの 4 年間に当科でプラン ルカスト (オノンドライシロップTM) を投 与した症例 159 例のうち, 投与日数が 28 日 以上の症例 104 例を対象とした。このうち、 アトピー性皮膚炎を合併する症例は 37 例、 合併しない症例は 67 例であった。アトピー 性皮膚炎の有無での年齢分布、プランルカ ストの投与状況、喘息への効果、アトピー 性皮膚炎の重症度の変化を検討した。

【結果】アトピー性皮膚炎を合併する症例 の平均年齢は 3.50 歳、アトピー性皮膚炎を 合併しない症例は平均 4.34歳であった。プ ランルカストの投与状況は、経過不良にて 中止した症例は 4 人のみであった。アト ピー性皮膚炎の重症・最重症の症例では皮 膚症状の改善がみられなかったが、中等症 の症例は軽症に移行し、軽症の症例では寛 快に至る症例もみられた。

【考案】気管支喘息の治療薬としてプラン ルカストは有用であるが、合併するアト ピー性皮膚炎に対してもある程度の効果が 示唆された。 
O55

\section{カゼインおよび乳清蛋白質の高度分解物 を配合したアレルギー用ミルクMA-Xの 臨床的評価}

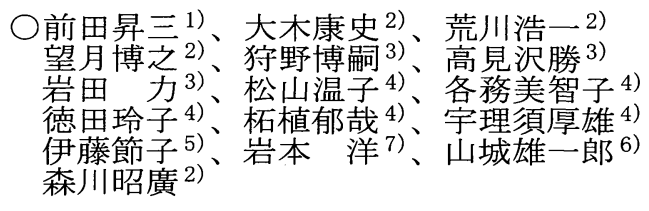

1)伊勢崎市民病院 小览科、2)群馬大学大学院医 学系研究科小児生体防御学分野、3) 東京大学大 学院医学系研究科生殖発達加龃医学専攻 小昌 医学講座、4)藤田保健衛生大学 医学部 小児科、 5) 同志社女子大学 生活科学部食物栄養科学科、 6) 順天堂大学医学部 小犇科学教室、7)森永乳 業株式会社 栄養科学研究所

【目的】カゼインおよび乳清蛋白質の高度 分解物を母乳の蛋白質比率に準じて配合す ることでアミノ酸バランスに配慮し、風味 を良好にした牛乳アレルギー用ミルク $\mathrm{MA}-\mathrm{X}$ の免疫学的・栄養学的有用性を評価 する。

【対象】牛乳アレルギーと考えられた乳幼 児 18 例（男児 12 例、女児 6 例、平均 11.4 \pm 5.6 ケ月齢)。

【方法】MA-Xの単独または母乳との併用 により対象の児を 3 ケ月間哺育し、その間 の身体発育状況と皮膚炎等のアレルギー症 状を観察すると共に、哺育前後で血液学・ 血液生化学検查、および総 $\mathrm{IgE}$ ・抗原特異 的 IgE值の測定を行った。

【結果】MA-Xによって哺育の中断を要す るようなアレルギー症状の出現は認められ ず、アトピー性皮膚炎児では哺育開始 2 週 間で症状の改善が認められた。また、哺育 前後で好酸球数の有意な低下 $(\mathrm{p}=0.002)$ を 認めた。身体発育に関しては、いずれの症 例も発育良好であり、成長のキャッチアッ プを認めた症例もあった。哺育前に貧血を 認めた児では、 3 ヶ月後には著明に改善し た。なお、哺育 3 ケ月後の血液学・血液生 化学検查では異常值は認められず、また総 $\mathrm{IgE}$ 值、牛乳特異的 $\operatorname{IgE}$ 值には明らかな変動 はみられなかった。

【結語】風味が良く飲みすやいMA-Xは、 除去食を行う牛乳アレルギー児の代替ミル クとして、免疫学的にも、栄養学的にも有 用であることが示唆された。
O56

\section{当院外来で実施した負荷間隔の長い食物 経口負荷試験 262 例の解析}

\author{
梅野英輔
}

医）梅野小児科内科医院

食物経口負荷試験の実施が推賞されてい るが、安全に行える方法のスタンダードは まだ存在しない。幾つかの方法が報告さ れているが、抗原の負荷間隔が短く、安全 の為入院の上実施することが奨められてい る。今回、当院外来で行っている負荷間隔 を長くした食物経口負荷試験の結果につい て解析したので報告する。

【対象及び方法】当院外来に通院中の食物 アレルギーが疑われる小児で、食物経口負 荷試験を実施した 262 例。負荷は市販の 食品のオープンチャレンジで実施した。 食品負荷の各ステップ後の観察時間は長く 取り、2 時間とした。

【結果】負荷試験陽性率は $64.1 \%$ で、有意 に男児が高かった。各食品のラストスコ アは、負荷試験陽性例で有意に高かったが、 症状出現の有無を推測できる差ではなかっ

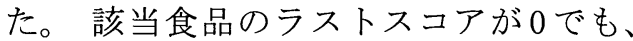
$48.7 \%$ が負荷試験陽性であった。各食品 の症状誘発時の負荷量（症状出現閾値）が 得られた。各段階の食物負荷後 60 分以上 経って症状が出現した例が $25.6 \%$ あった。

平均 5.7 ケ月の間隔で同様の負荷試験を 行い、有意な耐性を認めた。症状出現のた め処置を要した症例は、負荷試験陽性例の うち 15.5\%であり、該当食品のラストスコア が高い程有意に処置を要した。

【考案】外来での食物経口負荷試験におい ては、各段階の負荷後の観察時間は十分長 く取る必要があると思われた。試験陽性 例に負荷試験をくり返す間隔に関する 1 つ のエビデンスが得られた。 
$\mathrm{O} 57$

\section{低年齢児に対する外来食物負荷試験につ いて}

○池田有希子 1)、今井孝成 2)、小俣貴嗣 2) 富川盛光 ${ }^{2)}$ 、田知本寛 ${ }^{2)}$ 、宿谷明紀 ${ }^{2)}$ 海老澤元宏 1 )

1)独立行政法人 国立病院機構 相模原病院 臨 床研究センター アレルギー性疾患研究部

2)独立行政法人 国立病院機構 相模原病院 小 児科

02 年 10 月〜’04年 6 月まで低年齢児を対 象に当科外来で行った食物負荷試験 165 例 を報告する。食物負荷試験は診察上異常の ない状態でオープン負荷にて 15 分毎に負 荷量を増加し 5 回摂取した後又は症状出現 後 1 時間経過観察し判定した。対象は男 111 例、女 54 例、平均年齢 $1.9 \pm 0.1$ 才で、負 荷試験は全卵 16 例 (陽性率 (以下略)：19\%) 全卵の加工品 6 例 $(33 \%)$ 、卵黄つなぎ 6 例

$(0 \%)$ 、卵黄固ゆで 23 例 $(4 \%)$ 、乳製品 43 例 $(49 \%)$ 、小麦 39 例 $(38 \%)$ 、大豆 9 例 $(0 \%)$ 、魚介・鶏肉各6例、魚卵・果物各 3 例、そば 2 例、その他 3 例であった。全体 として陽性 45 例、陰性 118 例、判定不能 2 例で、陽性例で皮膚症状 42 例、呼吸器症状 11 例、消化器症状 2 例、エピネフリンの筋 注例は3例であった。IgE CAPRAST法によ るクラスの平均值は卵白 2.2 (抗体価 : 5.1) 卵黄 1.3 (1.2)、乳 1.8 (2.1)、小麦 $2.2(7.4)$ 、 大豆2.0(8.5) であった。今回の対象は0 才〜 5 才の低年齢児対象で、判定不能例は 2 例のみだったが、陽性例中 $24 \%$ に呼吸器 症状を認めショック症状への進展可能例も 認めた。以上のことから負荷試験は十分注 意が必要であり気軽に家で行うことは控え るべきである。心理的要因等バイアスの入 らない低年齢児においてはオープン負荷で 十分判断可能であると考えられた。
$\mathrm{O} 58$

\section{外来における食物アレルギー児に対する 食物負荷試験}

$\bigcirc$ 足立陽子 ${ }^{1)}$ 、濱道美紀 ${ }^{1)}$ 、岡部美恵 ${ }^{1)}$ 板澤寿子 1)、尾上洋一 2)、足立雄一1) 海老澤元宏 3 )、宮脇利男 1)

1) 富山医科薬科大学 医学部 小児科

2) 富山県立中央病院 小児科

3) 国立病院機構相模原病院 小児科

【はじめに】食物アレルギーの基本的な治 療は原因食物の除去であるが、心身両面一 の影響を考慮して食物除去を最小限に留め ることが重要である。一方、治療方針決定 の根拠を得るための食物負荷試験は、その 煩雑さや危険性などから敬遠されることが 多い。今回、当科外来での実施状況を報告 する。

【対象と方法】8カ月から 9 歳の食物アレル ギー児、24名。原因食物の同定と耐性獲得 の有無をみる目的で、「食物アレルギーの実 態及び誘発物質に関する研究」のために供 与された負荷試験食を用いて行った。食物 負荷は延べ29回で、二重盲検で行ったのは 21 例であった。

【結果】全卵; 13 名（平均月齢 28 力月）で 陽性は 6 名、牛乳; 9 名（41力月）で陽性 は 3 名、小麦; 4 名（12力月）で陽性は 1 名、 大豆； 3 名（39 力月）で全例陰性であった。 誘発症状は、皮膚（8）、呼吸器（3）、消化 器 (3)、不機嫌（2）であり、抗ヒスタミン 薬、ステロイド薬、気管支拡張薬などを投 与した。全員帰宅可能であり、症状の再燃 は認めなかった。

【考察】食物負荷試験は外来でも実施可能 と考えられるが、対象の選択や負荷試験の 時期については今後の検討課題である。 
O59

\section{特異的 $\lg E$ 抗体、HRT 検査亡食物負荷テ ストの関係}

○鈴木啓文、染谷研一、高増哲也 栗原和幸

神奈川県立こども医療センター

【目的】食物アレルギーに対する除去食を 解除する際の食物負荷テストの結果を、特 異的 IgE 抗体、HRT 検查で予測が可能かを 検討した。

【方法】対象は、特異的 IgE抗体 (CAP法)、 HRT（シオノギ）検查後に食物負荷テスト を行ったのべ 51 例。特異的 IgE抗体值、HRT クラス、ヒスタミン遊離率と食物負荷テス 卜の結果とを $\mathrm{t}$ 検定、 $\chi_{2}$ 検定で比較検討し た。

【結果】䳕卵負荷テスト 26 名中、陽性 $(+)$ 9 名・陰性（一）17名。両群の平均値は、 卵白 IgEは十群 7.35、一群 4.41(n.s.)。オボ ムコイド IgEは十群 12.3、一群 $2.2(\mathrm{p}<0.05)$ 。 卵白HRT クラスは十群2.8、一群2.4(n.s.)。卵 白遊離率／コントロール (抗ヒト IgE 抗体) 遊離率は十群 4.822、一群 3.126(n.s.)。卵白 IgE10 以上で負荷テスト陽性率 $73 \%$ 、10末 満で $14 \%(\mathrm{p}<0.01)$ 。オボムコイドIgE7 以上 で陽性率 $88 \%$ 、7 未満で $11 \%(\mathrm{p}<0.001)$ 、 卵白HRT3 以上で陽性率 $41.2 \%$ 、2 以下で 18.2\%(n.s.)で、有意差を認めなかったが、 卵白遊離率/コントロール遊離率 3 以上で は陽性率 $60.0 \%$ 、3 未満で $21.7 \%(\mathrm{p}<0.05)$ であった。

【結論】食物負荷テストの結果の予測には、 特異的 IgE抗体值が HRT クラスよりも優れ ているが、ヒスタミン遊離率の利用でHRT 検査も食物負荷テストの結果を予測し得た。
$\mathrm{O} 60$

ßラクトグロブリン消化ペプチドにおけ るB細胞、 $\mathrm{T}$ 細胞エピトープの in vitro検 出

○近藤 應、深尾敏幸、加藤善一郎 寺本貴英、篠田紳司、近藤直実

岐阜大学大学院 医学研究科 小児病態学

【目的】食物アレルギーの原因食品のうち、 ミルクは、子供が最も早期に摂取する外来 抗原である。我々は今までに、牛乳の主成 分である $\beta$ ラクトグロブリン (BLG) 特異的 $\mathrm{T}$ 細胞クローンを樹立し、アレルギー病態 の治療に結びつく T 細胞応答の誘導を試み ている。今回、我々は、BLGを種々の消化 酵素で切断したペプチドを作成し、個々の 患者において B 細胞エピトープと T 細胞エ ピトープが残存しているかを in vitroにて 検討を行った。

【方法】食品 BLG 種々の消化酔素で切断 したペプチドを作成し、複数のミルクアレ ルギー患者において、 $\mathrm{T}$ 細胞エピトープと B 細胞エピトープの検討を行った。B 細胞エ ピトープについては、患者血清を抗体とし

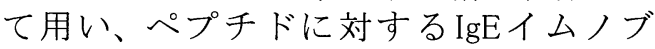
ロット、ドットブロットを用いて評価した。 また、 $\mathrm{T}$ 細胞エピトープについては、患者 末梢血単核球を用いてペプチドに対するリ ンパ球増殖反応にて評価した。

【結果】B細胞エピトープについては $\operatorname{IgE} イ$ ムノブロットではペプチドに対する評価は 難しく、ドットブロットが評価に有効で あった。 $\mathrm{T}$ 細胞エピトープの評価は現在検 討中である。

【考按】B細胞エピトープと $\mathrm{T}$ 細胞エピトー プの有無が in vitro で明らかになれば、ミル クアレルギー患者へのペプチド経口負荷の 安全性の指標となり、酵素消化ペプチドの $\mathrm{T}$ 細胞応答による免疫寬容誘導につながる ことが期待できる。 
O61

\section{抗原特異的 $\lg E$ 存在下での経口抗原暴露 に対するT細胞反応性の変化}

\author{
○小俣合歓子 1)、安冨素子 2)、山田彰子 1) \\ 大嶋勇成 ${ }^{1)}$ 、烏山 - 3 )、眞弓光文 ${ }^{1)}$
}

O62

家屋塵中の食物抗原による感作の可能性

○増田 進 ${ }^{1)}$ 、宇理須厚雄 ${ }^{2)}$ 、松山温子 ${ }^{2)}$ 各務美智子 2)、徳田玲子 2)
1)福井大学 医学部 病態制御医学講座 小児科 2) 福井社会保険病院 小児科

3) 東京医科歯科大学

【目的】抗原特異的 $\operatorname{IgE}$ の存在が、T細胞の 反応性にどの様な影響を与えるかを解析し、 経口免疫寛容成立に及ぼす影響を検討する。 【方法】 OVA 特異 IgE 産生トランスジェ ニックマウス IgE-TgにOVAを経口投与し た後、脾細胞を再刺激し細胞増殖とサイト カイン産生を評価した。また、抗原暴露前 の T細胞の反応性を評価するため、OVA特 異 TCR 発現トランスジェニックマウス TCR-Tg と、OVA特異IgEとTCRのダブルト ランスジェニックマウス TCR/IgE-Tgから $\mathrm{T}$ 細胞を分離し野生型脾細胞を抗原提示細 胞として刺激した。

【結果】OVA 3 回投与後では、IgE-Tgに抗 原特異的細胞増殖と IL-4、IFN- $\gamma$ 産生が誘 導された。また、OVA 50mgより $0.5 \mathrm{mg}$ 投与 でより強い反応が認められた。6 回投与後 では、 $\operatorname{IgE}-\mathrm{Tg}$ の抗原特異的反応の減弱を認 めた。一方、野生型マウスでは、抗原特異 的反応はほとんど誘導されなかった。抗原 暴露前の $\mathrm{TCR} / \mathrm{IgE}-\mathrm{Tg}$ から分離した $\mathrm{T}$ 細胞 は TCR-Tgから分離した T 細胞より抗原特 異的細胞増殖の六進を認めた。

【考察】抗原特異的 IgE 存在下では、抗原 の経口投与により一過性に抗原特異的 $\mathrm{T}$ 細 胞反応誘導されるが、抗原投与の反復によ り免疫寛容が誘導されると考えられた。ま た、抗原特異的 $\mathrm{IgE}$ の存在は、抗原暴露前 の $\mathrm{T}$ 細胞反応性にも影響する可能性が示唆 された。

\begin{abstract}
1) 特定医療法人財団新和会 八千代病院 小児科 2) 藤田保健衛生大学坂文種報徳会病院 小览科
\end{abstract}

【症例】生後 5 力月の女览。生直後から頭 部, 躯幹, および四肢に掻痒を伴う湿疹が 出現し, 5 力月の時, 湿疹病変が増悪した。 母親がATLキャリアーのため, 児は完全人 工栄養で育った。患児自身，離乳食開始前 であり, 鶏卵や小麦を捸取したことはな かった。 5 力月時の血液検査で, 血清総 $\mathrm{IgE}$ 值は $151 \mathrm{IU} / \mathrm{ml}$, 特異的 IgE抗体は卵白 14.6, オボムコイド 1.60 , ミルク 0.98, 小麦 1.36 , 米 $<0.34$, ソバ $<0.34 \mathrm{UA} / \mathrm{ml}$ であった。完全 人工栄養で育てられたが，ミルク以外の食 品の感作があり, 家屋塵中に食物抗原の存 在の可能性も考えた。居間(畳の上に綿マッ 卜）, 客間（畳），隣の居間（絨进炎），隣の 客間（絨㘪）, 布団の計 5 箇所から塵を電気 掃除機（吸引仕事率260watts）を用いて採 取した。卵, 牛乳, 小麦, ソバ, 落花生につ いて塵中の抗原濃度を.日本八ム K.K. 製 FASTKITを用いて測定した。

【結果】家屋塵中の抗原濃度 ( $\mu \mathrm{g} / \mathrm{g}$ dust) は, 居間（綿マット）で卵 20.5, 牛乳 93.4, 小麦 85.2 , ソバ 0.1 , 落花生 0.9 , 客間 (疊) で卵 43.1 , 牛乳 46.6 , 小麦 165.5 , ソバ 0.0 , 落 花生 0.4, 隣の居間（絨毯）で卵 92.3 , 牛乳 58.6 , 小麦 48.9 , ソバ 0.0 , 落花生 2.0 , 隣の客 間 (絨毯) で卵 8.4 , 牛乳 43.7 , 小麦 23.1 , ソ バ 0.0 , 落花生 1.2 , 布団で卵 5.6 , 牛乳 44.3 , 小麦 29.8 , ソバ 0.1 , 落花生 0.7 であった。

【結論】卵白，小麦に感作を認めた完全人 工栄養児において患児の家屋塵中に卵と小 麦が存在しており, 経気道感作あるいは経 皮感作の可能性が示唆された。 
$\mathrm{O} 63$

\section{ダイヤモンドコーティング高密度集積蛋 白チップによるオボムコイドと、 $\alpha \cdot \beta$ カゼインのエピトープ解析（食物アレル ギーの高感度エピトープ解析）}

○山川由美子 1,2)、多田仁美 1)、澤淵貴子 1) 新田麗子 1)、木戸博 1 )

1) 徳島大学 分子酵素学研究センター 酵素分子 化学部門

2) 大塚製薬株式会社 大塚ライフサイエンス事業 部 NBC 遺伝子解析センター

子供の食物アレルギーが増えているが、 我が国での主な原因は卵、牛乳、小麦であ る。アレルギーの原因となるアレルゲンの 成分はこれまで種々の方法で判定されてき たが、年齢・病状とともに変化するエピト一 プと、そのエピトープとの反応性を定量的、 経時的に評価できる測定系は無かった。 我々はシリコン及びガラス基板にダイヤモ ンドあるいはDLCをコーティングした蛋 白チップに、オボムコイドとカゼインのエ ピトープライブラリーを搭載したアレルゲ ンエピトープ解析チップを開発した。ライ ブラリーは卵の中で最も抗原性の高いオボ ムコイドと、牛乳の中で抗原性のあるカゼ インを選び、種々のプロテアーゼによる切 断ライブラリーと、すでに報告されている MHC class2 抗原ペプチドライブラリーを 用いた。その結果 MHC class2 に結合するエ ピトープとして判明している5-16残基の 合成ペプチドと比べ、その両端あるいは片 側にペプチド鎖が伸びたフラグメントペプ チドの方が、約 10 倍抗体と強く反応するこ とが判明した。このことは、患者のエピトー プスクリーニングと抗体との反応性の評価 には、MHC class2 結合ペプチドを含むぺプ チド鎖の長いライブラリーの作成が、より 効果的であることが判明した。
$\mathrm{O} 64$

\section{イクラアレルギーの抗原分析と交差抗原 性について}

○中島陽一 1)、近藤康人 1)、河村牧子 1)

柘植郁哉 1)、各務美智子 1)、徳田玲子 1) 宇理須厚雄 ${ }^{1)}$ 、小山晴美 ${ }^{2)}$ 、山田一惠 ${ }^{3)}$ 安田俊隆 ${ }^{4)}$

1)藤田保健衛生大学医学部小児科

2)群馬大学小児科、3)山田医院

4) 東洋水産株式会社

【目的】イクラアレルギーはアナフィラキ シーのような重篤な報告が多く、そのため イクラを含む食品の表示が推奨されている。 それにもかかわらずその抗原性に関する報 告は少なく、鶏卵や魚肉との交差抗原性に 関しての解答も得られていない。今回イク ラアレルギー患者の血清を用いて、他の魚 卵（カズノコ、タラコ）、サケや鶏卵との共 通抗原性につき検討を行った。

【方法】イクラアレルギー児 2 名の患児血 清を用いマイクロプレートを固相とした ELISA inhibitionを用い、イクラ抗原に対す る IgE 結合能の魚卵、サケ、鵎卵による抑 制につき検討した。

【結果】イクラに対する IgE 結合能は他の 魚卵やサケ抗原の添加により容量依存性に 抑制が見られたが、50\%以上の抑制が得ら れたのはカズノコ抗原のみであった。一方 鵎卵抗原添加による抑制は見られなかった。

【結論】過去の報告と同様、イクラに対す る IgE 結合能はカズノコ、タラコにより抑 制され、鵎卵では抑制されなかった。しか し、イクラ抗原に対する IgE抑制能にカズ ノコとタラコで差が見られたことから、今 後さらに症例を増やし検討していく予定で ある。 
O65

\section{ラテックス抗原とカキ（柿）抗原との交 叉反応性についてELISA inhibition test での検討}

○徳田玲子 1)、中島陽一 2)、平田典子 1) 河村牧子 2)、松山温子 1)、各務美智子 1) 近藤康人 2 、柘植郁哉 ${ }^{2)}$ 、宇理須厚雄 ${ }^{1)}$

1) 藤田保健衛生大学坂文種報徳会病院 小児科 2) 藤田保健衛生大学 小児科

【目的】ラテックス抗原とカキ（柿）抗原 の交叉反応性について検討した。(対象) ラ テックスと柿に対する特異的 IgE 抗体がと もに陽性であり、柿摂食による即時型アレ ルギーを呈した 2 症例、柿とバナナ摂食に よる即時型アレルギーとラテックスアレル ギーを呈した 1 症例とラテックスアレル ギーを疑う 1 症例の計 4 症例。年齢 1 歳 6 力 月〜 13歳であった。

【方法】柿とバナナは果肉よりそれぞれ抗 原を抽出し、ラテックス抗原は本大学皮膚 科松永教授からより供与されたものを使用 した。各プレートに抗原 $100 \mu \mathrm{g} / \mathrm{ml} コ ー$ ティングを行いELISA inhibition test を施行 した。(結果・考察) 4 症例中 3 症例でラテッ クス抗原固相が柿抗原で約 $80 \%$ の抑制が かかり、1症例で柿抗原固相がラテックス 抗原で約 $60 \%$ の抑制がかかった。また、バ ナナ抗原と柿抗原との間でも互いに約 55 〜 75\%の抑制が認められその交叉抗原性 が証明された。バナナ抗原についてはラ テックス抗原との交叉反応性の報告も多く、 ラテックスフルーツ症候群の代表食物とし て認知されているが、柿についてのアレル ゲンやその交叉反応性についての研究はほ とんどされておらず今回の結果は興味深い ものとなった。
O66

\section{加熱脱オボムコイド卵白を用いた経口減 感作療法による末梢血単核球のIL-4 - INF- $\gamma$ 産生能への影響}

○山田一惠 ${ }^{1)}$ 、中島陽一 2)、河村牧子 2) 松山温子 2)、各務美智子 2)、徳田玲子 2) 近藤康人 2)、柘植郁哉 ${ }^{2)}$ 、宇理須厚雄 ${ }^{2)}$ 木村 守3)、柳原行義 4)、鳥居新平5)

1) 山田医院、2)藤田保衛大小児科

3) キューピー株式会社、4)国立相模原病院

5) 愛知学泉

【目的】鵎卵アレルギー患者を対象に低ア レルゲン化した加熱脱オボムコイド卵白 クッキーを用いた経口減感作療法を実施し、 末梢血単核球の IL-4 IFN- $\gamma$ 産生能の変化 を検討した。

【対象】経口負荷試験で加熱卵白陽性 10 例 （年齢 1 歳 6 力月～12 歳）と凍結乾燥卵白 陽性 14 例 (年齢 2 歳〜 6 歳)。加熱脱才ボム コイド卵白（鶏卵白 1 個相当）入りのクッ キーを 4 週間摂取後に、卵白抗原による負 荷試験で判定した。

【方法】末梢血単核球を卵白で培養し、上 清中の IL-4、IFN- $\gamma$ を測定し、stimulation index(SI)を求め、減感作によるサイトカイ ン産生能の変化率を post-SI/pre-SI で表し た。

【結果と結論】IL-4の変化率は陰性化群 （8例）が非陰性化群（16 例）に比べて有 意 $(p=0.02)$ に低值であった。変化率が 1 以上の例が、陰性化群（1/8） は非陰性化群

(8/16) よりも少ない傾向（カイ二乗検定 $\mathrm{P}=0.07)$ であった。IFN- $\gamma$ の変化率は陰性 化群が小さい傾向であった $(\mathrm{p}=0.08)$ 。変化 率が 1 以上の例は陰性化群 $(4 / 8)$ と非陰性 化群（11/16）との間に差はなかった $(\mathrm{P}=0.37)$ 。以上から、経口減感作によって 卵白負荷試験が陰性化する群ではTh2 サイ トカイン（IL-4）だけでなく、Th1サイト カイン $($ IFN- $\gamma$ ) の産生能も低下傾向がみ られた。 
$\mathrm{O} 67$

\section{人工栄養がカゼイン特異的リンパ球増殖 反応、IL-4およびIFN- $\gamma$ 産生に及ぼす影 響}

○木村光明、小尾真喜子、後藤元宏

静岡県立こども病院 感染免疫アレルギー科

【はじめに】われわれは乳児アトピー性皮 膚炎（AD）患者を対象に、栄養法と IgE抗 体産生との関係を検討し、人工栄養児の方 が母乳栄養児より牛乳特異的 IgE抗体レべ ルが低いことを明らかにした。また人工栄 養児では母乳栄養児より末梢血単核球によ るカゼイン特異的IFN- $\gamma$ 産生が高いこと を報告した。これらの所見は人工栄養が Th1 タイプのサイトカイン産生を誘導・促 進することにより、IgE抗体産生を抑制する ことを示唆している。

【目的】カゼイン特異的リンパ球増殖反応 やIL-4産生も併せて測定し、人工栄養がリ ンパ球機能へ及ぼす影響の全体像を明らか にする。

【対象】生後 7 ヶ月までの乳児 $\mathrm{AD}$ 患者 25 名。内訳は母乳栄養および主に母乳栄養群

（B群）12名、人工栄養および主に人工栄 養群 6 名、混合栄養群 7 名。

【方法】IgE抗体はCAPsystem で測定した。 末梢血単核球を $\alpha$-カゼインで刺激し、リ ンパ球増殖反応をフローサイトメトリーで、 IL-4 及びIFN- $\gamma$ 産生量をELISA法で測定 した。

【結果】リンパ球増殖反応は人工栄養群の 方が母乳栄養群より高かったが、有意差は 見られなかった (805 vs 591)。IFN- $\gamma$ 産生 は人工栄養群の方が有意に高かった $(73.7$

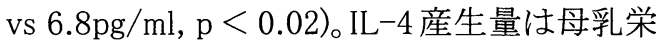
養群と人工栄養群の間で差がなかった $(<$ $200 \mathrm{vs}<200 \mathrm{fg} / \mathrm{ml}$ )。

【考察】人工栄養はカゼイン特異的 $\mathrm{T}$ 細胞 の増殖には明らかな影響を及ぼすことなく、 サイトカイン産生パターンをTh1型にシフ トさせることが明らかになった。
O68

CFSE 染色リンパ球を用いた鶏卵アレル ギ一疾患の病因抗原の診断一抗原除去に よる症状改善群の症例経過一

○小川倫史 ${ }^{1)}$ 、佐伯敏亮 ${ }^{1)}$ 、川野 豊 ${ }^{2)}$ 野間 剛1)
1) 北里大学 医学部 小児科
2)横浜赤十字病院 小児科

【目的】食物アレルギ一疾患の病因抗原の 診断は、経口負荷試験、特異 $\lg E$ の検出、 リンパ球幼若化テスト、リンパ球 IL-2 反応 試験などにより行われる。CFSE (carboxy fluorescein diacetate succinimidyl) 色素で染 色したリンパ球を用いた食物アレルギーの 診断法は簡略で臨床的に有用であることを 既に示した。今回、鶏卵アレルギー患児の 抗原除去により症状の改善を認める症例に ついて経過を解析した。対象：鶏卵摂取に より湿疹の増悪を認め、卵白 IgERAST 陽性 を示す1才から 2 才までの鷄卵アレルギー 患児群のうち鵎卵除去で症状の改善を認め た症例。

【方法】卵白アルブミン (OVA) 抗原を反応 させた末梢血単核細胞をCFSEで染色後 6 日間培養したのちFACSを用いて蛍光強度 減少細胞群の比率を算定した。

【結果】患児群では、OVAで刺激した単 核細胞のCD4 陽性リンパ球亜群において 蛍光強度減少細胞群の増加を認めた。PHA で刺激した場合も OVAで刺激した場合と 同等であった。除去などの加療により症状 が改善するにしたがって、蛍光強度減少細 胞群の増加の程度は軽度であった。PHA で 刺激した場合はその比率の低下は認めな かった。よって鶏卵アレルギー患児では、 鶏卵刺激リンパ球の CD4 陽性亜群の蛍光 強度減少細胞群の比率は、症状の改善にし たがって低下すると考えられた。結語: 本 法は鶏卵アレルギー患者の病因抗原の診断 や病勢の把握に用いうると考えられた。 
O69

\section{培養気道上皮細胞を2本鎖RNAで前処置 すると、IL-4 で誘導される eotaxin-3 産生 が増強する。}

○山本修一、小林育子、辻 功介 西奈津子、宮崎倫子、在津正文 室英理子、稲田成安、市丸智浩 濱崎雄平

\section{佐賀大学 医学部 小巟科}

【背景・目的】気道上皮細胞からのエオタ キシンの産生、特に eotaxin-3 が IL-4 や IL13 により誘導される事実は、気道上皮細胞 が気道の好中球性炎症のみならず、好酸球 性（アレルギー性）炎症にも関与している ことを示唆している。気道上皮細胞へのウ イルス感染や、合成 2 本鎖 RNAの刺激によ り、気道上皮細胞は各種のケモカインを産 生することが知られているが、 eotaxin-3の 産生に関する報告はない。

【方法】ヒト培養気道上皮 BEAS-2B 細胞に おける合成 2 本鎖 RNA、 poly(IC) transfection の、IL-4-induced eotaxin-3 産生に対する効 果を検討した。eotaxin-3 遺伝子発現をRTPCRで、蛋白産生をELISAにて検討した。

【結果】poly(IC) transfection 後 2 日間培養し たBEAS-2B細胞における IL-4で誘導され る eotaxin-3 mRNA 発現、蛋白産生を mock transfection と比較した時、いずれも有意に 増強された。

【結論】poly(IC) transfectionは培養気道上 皮細胞におけるIL-4-induced eotaxin-3 産 生を増強した。このことはウイルス感染時 の気管支喘息発作の増悪を説明するかもし れない。
$\mathrm{O} 70$

\section{SEBによるヒト末梢血単核球からのサ イトカイン産生に対する免疫グロブリン の抑制効果}

○加藤久美子 1)、伊藤浩明 2)、木村量子 1$)$ 広瀬 泉 ${ }^{1)}$ 、坂本龍雄 ${ }^{1)}$

1)名古屋大学 医学研究科 小览科学

2)あいち小児保健医療総合センター

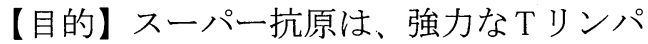
球活性化による食中毒やトキシックショッ クへの関与のみならず、アトピー性皮膚炎 (AD)の増悪因子としても注目される。 $\mathrm{AD}$ 患 者の一部 はStaphylococcal enterotoxin B (SEB) 特異 IgE抗体が陽性である事が知られ ているが、SEB特異IgG抗体の存在やその役 割に関する検討は少ない。我々は、SEB 特 異 IgG抗体を含むガンマグロブリン製剤

（ヴェノグロブリン IH、以下 $\gamma-\mathrm{GL}$ ）が、 SEB 刺激に対して及ぼす効果を検討した。

【方法】 $\gamma-\mathrm{GL}$ 及びAD 患者血清中のSEB 特 異 IgG 抗体を、ELISA 法にて測定した。ま た、健常成人の PBMCを $100 \mathrm{ng} / \mathrm{ml}$ の SEB で 72 時間刺激培養し、リンパ球増殖反応及び IFN- $\gamma 、 \mathrm{IL}-4$ 産生に対する $\gamma-\mathrm{GL}$ 及びその 分画による抑制効果を検討した。

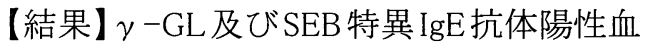
清 $(\mathrm{n}=11)$ からは、SEB 特異 IgG 抗体が検出さ れた。一方、SEB特異 IgE抗体陰性血清 $(n=17)$ では、7例 (41\%) のみが SEB 特異 IgG 抗体陽 性であった。 $\gamma$-GLは、SEB刺激による増 殖反応と IFN- $\gamma$ およびIL-4 産生をほぼ完 全に抑制した。この抑制効果は、 $\gamma$-GLの Fab、F(ab')2 分画で同等に認められた。一 方 $\mathrm{Fc}$ 分画では、増殖反応の抑制効果は認め られなかったが、IFN- $\gamma$ 産生を部分的に抑 制する傾向が認められた。

【結論】血清中に含まれる SEB特異IgG抗体 は、主として中和活性によって SEB 刺激に 対するリンパ球の増殖反応およびサイトカ イン産生を抑制する事が示唆された。さら に Fc 分画も、サイトカイン産生抑制に関与 する可能性が示唆された。 
O71

\section{立体構造に基づく分子設計 : 高安定性 IL- 18 の作成}

○山本 裕、加藤善一郎、松郎英治 李 愛蓮、面家健太郎、橋本和幸 大西秀典、近藤直実

岐阜大学 大学院医学研究科 小览病態学

【目的】IL-18はアレルギーにおいて重要な 役割を果たしているが、治療的アプローチ に利用することを目的とした立体構造・結 合様式に基づいた高安定性 hIL-18の設計・ 作成を行ったので報告する。

【方法】hIL-18ベクターを作製、蛋白の発 現・精製し、酸化条件下での多量体分析お よびヒト骨髄単核細胞を用いた生物活性測 定を行った。また hIL-18・receptor 複合体 構造解析に基づき変異体設計を行い、5種 類の変異体蛋白に関しても同様に多量体分 析、生物活性測定を行った。

【結果】 wild typeでは酸化後、著しい多量 体化パターンを示し全てのシステイン残基 が多量体化に関与していることが確認され た。また hIL-18の立体構造から 4 つのシス テイン残基をセリン残基に置換しても hIL18 の立体構造及びレセプター結合能が保 たれることが推定されたため、全てのシス テイン残基をセリン残基に置換した IL-18AS 蛋白を作製したところ、酸化処理後でも 多量体化パターンを全く示さず、全く活性 低下を認めなかった。

【考察】変異体蛋白 IL-18-AS は酸化条件下 においても生物活性を保持した状態で高い 安定性を有した。蛋白製剂を治療に用いる 際、貯蔵、投与における安定した性状が求 められている。今後、蛋白工学的改良への 重要な基盤になると考えられる。
$\mathrm{O} 72$

ヒト培養気道上皮細胞における去痰薬の 細胞内レドックス状態に与える影響

○戸所 誠 1)、望月博之 2)、滝沢环已 2) 荒川浩一2)、徳山研一2)、森川昭廣 2 )

1) 原町赤十字病院 小览科

2)群馬大学 大学院 小坚生体防御学

【目的】喘息の治療に頻用される去痰薬に は、抗酸化作用があることが知られている。 これまで我々は、ヒト培養気道上皮細胞で ある Calu-3 細胞を用いて、オゾン曝露によ る酸化ストレスと細胞障害との関連を検討 してきたが、今回、去痰薬による気道上皮 細胞の細胞内レドックス状態の変化につい て検討したので報告する。

【方法】培養した Calu-3 細胞に対し、N-ア セチルシステイン、L-カルボシステイン、 アンブロキソールを投与し、細胞内のレ ドックス状態の変化を GSH,GSSG の測定に より求めた。

【結果】N-アセチルシステインでは、高濃 度の投与ではCalu-3を還元状態にさせる 傾向がみられた。この作用は、2 時間で最 大となることがわかった。L-カルボシステ イン、アンブロキソールとも、同様の傾向 がみられた。

【結論】去痰薬の投与により、気道上皮細 胞では細胞内が還元状態になる傾向がみら れた。現在、去痰薬で前処置した気道上皮 細胞におけるサイトカイン産生の影響につ いて検討中である。 
$\mathrm{O} 73$

\section{小児アレルギー疾患患者における細胞内 サイトカインの年齢別検討}

\author{
○川本典生 ${ }^{1)}$ 、金子英雄 ${ }^{1)}$ 、竹村正男 ${ }^{2)}$ \\ 近藤直実 1)
}

1)岐阜大学医学部 小児病態学

2) 岐阜大学医学部附属病院 検查部

【目的】アレルギ一疾患において Th1, Th2 のアンバランスが指摘されている。特に小 児においては、獲得免疫の発達に伴う影響 を加味する必要がある。そこで、演者らは 年齢別にTh1, Th2 細胞の陽性率に関する年 齢別検討を行った。

【対象と方法】0歳から50歳までのアレル ギー疾患を持たない健常人群、また、気管 支喘息、アトピー性皮膚炎などのアレル ギー疾患を持つアレルギー群を対象とした。 末梢血をBrefeldin A 存在下にPhorbol 12myristate 13-acetate, Ionomycinを用いて 37 ${ }^{\circ} \mathrm{C}$ にて 4 時間刺激し、CD $4^{+} \mathrm{IFN}-\gamma^{+} \mathrm{IL}-4^{-}$細 胞をTh1, CD $4^{+} \mathrm{IFN}-\gamma^{-} \mathrm{IL}-4^{+}$細 胞をTh2, $\mathrm{CD} 8^{+} \mathrm{IFN}-\gamma^{+} \mathrm{IL}-4^{-}$細胞を $\mathrm{Tc} 1, \mathrm{CD} 8^{+} \mathrm{IFN}-\gamma^{-}$ $\mathrm{IL}-4^{+}$細胞を $\mathrm{Tc} 2$ として、フローサイトメー ターにて解析した。

【結果と考察】健常人群での Th1, Tc1, Th2 の陽性率は、年齢依存的に増加し、特に Th1，Tc1 は強い相関が認められた。Th1， Tc1 は Th2, Tc2 の抑制系としての㗢きがあ ると考えられるが、獲得免疫の発達ととも にTh1, Tc1の陽性細胞群が増加していくも のと考えられる。小児の気管支喘息群、乳 児のアトピー性皮膚炎群においては、健常 人群と比べて Th2 の陽性率が有為に高值で あったが、Th1，Tc1，Tc2に関しては、有為 な差を認めなかった。現在、特徴的な值を 示した症例について解析を進めている。
O74

\section{システイニルロイコトリエンによる単 球・マクロファージでのMCP-1産生}

○市山高志、長谷川真成、金子美保 松原知代、古川 漸

山口大学 医学部 小児科

【目的】単球・マクロファージはシステイ ニルロイコトリエン1（cysLT1）受容体を 有するがその機能は明らかでない。単球・ マクロファージの cysLT1受容体機能をサ イトカインの面から解析する。

【方法】1. 単球系 THP-1 細胞とヒト末梢 血CD14＋単球を用いて cysLT(LTC4、LTD4、 LTE4）刺激によるサイトカイン（TNF- $\alpha$ 、 IL-1 $\beta$ 、IL-2、IL-4、IL-6、IL-8、IL-10、 $\mathrm{MCP}-1 、 \mathrm{M}-\mathrm{CSF}$ 、 eotaxin) 産生を cytometric bead array 及びELISA で検討した。2. THP1 細胞を用いて cysLT 刺激による MCP-1の mRNA 発現への影響をRT-PCR で検討した。 3. ロイコトリエン受容体拮抗薬であるプラ ンルカスト水和物の上記 1 および 2 に対す る抑制作用を検討した。

【成績】1. THP-1 細胞と CD $14+$ 単球にお いて、cysLT刺激により MCP-1のみが産生 された。2. cysLT刺激により $\mathrm{MCP}-1$ の mRNA発現が増強した。3. プランルカスト 水和物は 1 および 2 を抑制した。

【結論】cysLT刺激により単球・マクロ ファージでの $\mathrm{MCP}-1$ 産生増強がみられ、そ の作用はプランルカスト水和物により抑制 された。 
$\mathrm{O} 75$

\section{衛生仮説検証の試み（第2 報）}

$\bigcirc$ 田中泰樹

国立病院機構新潟病院 小児科

【目的】これまで演者は第 40 回本学会にお いて、本邦でも衛生仮説が成立するものか どうか検証を試み、その結果を報告した。 今回は規模を拡大し新潟県内の小児科外来 を受診した患者を対象に乳児期の成育環境 についてアンケート調查を行った。

【方法】協力施設を受診したアレルギー疾 患以外の基礎疾患を持たない 5 歳以上の小 児 2166 名（5～22 歳、 $8.5 \pm 3.3$ 歳、男:女 $=1201: 947$ 、不明 18名) を対象に、ISAAC の問診票を用いて気管支喘息(以下、BA)の 有無を判定し(ISAAC診断喘息720名: 42.0\%)、また医師による診断も併せて行っ た（医師診断喘息1109名：62.4\%)。更に 家族歷と受動喫煙の有無のほか、同胞数や 同居家族数、1 歳までの成育環境（イヌ・ ネコの有無、乳児期の発熱、抗生剤投与の 有無、早期保育の有無、寝室・布団の掃除 頻度）についてアンケート用紙を用い問診 を行い、集計した。統計学的処理はロジス ティック回帰分析を用いた。

【結果】ISAAC 診断および医師診断喘息群 ともに、成育環境において有意差を認めな かった。

【考察】本邦（新潟県）では衛生仮説は成 り立ちにくいと考えられた。
O76

\section{アレルギー疾患発症前の腸内細菌叢に関 する検討}

○伊藤浩明 1)、森下雅史 ${ }^{1)}$ 、坂本龍雄 ${ }^{2)}$
1)あいち小児保健医療総合センターアレルギー科

2)名古屋大学大学院医学研究科 小児科学

【目的】我々は、重症アトピー性皮膚炎の 乳児に於ける腸内細菌叢の異常を報告して きた。今回、その異常がアレルギー発症前 から存在するか否かを知る目的で、乳児期 早期の腸内細菌叢を検出し、前方視的に検 討した。

【方法】中等症以上の食物アレルギー・ア トピー性皮膚炎で当科受診中の兄姉（1例 は母親）を持つ乳児 13 例（日齢 41-169、平 均 75.0 日）の粪便中の細菌叢を、光岡らの 方法で定量培養した。その後、皮膚プリッ クテスト及びIgE抗体測定を含めてアレル ギー発症について追跡した。

【結果】13 例中、Bifidobacterium は 12 例、 Bacteroides は 4 例、Clostridium Lecithinase

（-）は 5 例に検出された。 $20 \%$ 以上の好気 性菌が 4 例で検出された。平均 4.0 か月の皮 膚プリックテストで、4例が卵白・牛乳・ 枝豆のいずれかに陽性。平均 5.4 か月で、7 例が 1 種類以上の食物特異的 $\operatorname{IgE}$ 抗体陽性 $(\mathrm{CAP}-\mathrm{FEIA}>0.7 \mathrm{UA} / \mathrm{ml})$ であった。平均 9.1 か月で、アトピー性皮膚炎を5例に認めた。 検討した範囲では、腸内細菌叢の特徵と $\mathrm{IgE}$ 抗体産生・アトピー性皮膚炎の発症の間に 有意な関連は認められなかった（Fisherの 直接確率)。

【考察】今回対象とした乳児は、強い家族 歴を反映してアレルギー発症率が高く、そ の中では腸内細菌の特徵とアレルギー発症 の間に関連を認めなかった。しかし、全体 として生後1 か月には認められる嫌気性菌 の発育が遅延する傾向があり、アレルギー 素因が腸内細菌叢の発達に何らかの影響を 及ぼしていることが示唆された。 
O77

Th1/Th2 パラダイムから検討した加齢に よるアトピー性皮膚炎の差異

○小野三佳 ${ }^{1)}$ 、吉原重美 ${ }^{1)}$ 、山田裕美 ${ }^{1)}$ 阿部利夫 ${ }^{1)}$ 、小林幹子 ${ }^{2)}$ 、大西誉光 ${ }^{2)}$ 渡辺晋一2)、有阪 治 1 )

1)獨協医科大学 小览科

2) 帝京大学 医学部 皮膚科

【目的】近年、アトピー性皮膚炎 (AD)をは じめとするアレルギー性炎症にヘルパーT 細胞が関与していることが報告されている。

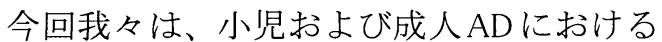
アレルギー性炎症の関与および年齢による 差異を検討する目的で本研究を実施した。

【対象および方法】小児 $\mathrm{AD}$ 群：54例およ び成人 $\mathrm{AD}$ 群: 24 例の $\mathrm{AD}$ 患者に対し、薬物 治療前の Th $1 / \mathrm{Th} 2$ 值をフローサイトメト リー法にて測定し、コントロール群 : 健常 人 31 例と比較検討した。

【結果】 $\mathrm{AD}$ 患者の Th1/Th2 值 (mean $\pm \mathrm{SE}$ ) は、小児 $\mathrm{AD}$ 群で $5.9 \pm 0.5$ 、成人 $\mathrm{AD}$ 群で $8.1 \pm 1.4$ と、両者ともコントロール群の $12.5 \pm 1.4$ と比較して有意な Th $1 / \mathrm{Th} 2$ の低 值を示した $(\mathrm{p}<0.05)$ 。小児の Th1/Th2 は、 成人と比較して、有意差はないもののより 低值を示した。また、小児および成人 $A D$ 群において、Th2\%の増加は認めずTh1\%は 健常人に比べて有意な減少を示した。

【結論】本研究の Th1/Th2 值の解析から、 $\mathrm{AD}$ 患者のTh1/Th2の低下はTh1の減少に よる相対的 Th2 有意によるものと考えられ た。小児期の段階でTh2を抑制することに よりTh1/Th2バランスが保たれ、AD発症や 増悪を抑制できる可能性が示唆された。
O78

\section{公共施設におけるダニ污染の実態調査 一公共施設にじゅうたん、畳は不要一}

\author{
○小倉由紀子、小倉英郎、小野美樹
}

(独) 国立病院機構高知病院 臨床研究部・アレ ルギー科 (小児科)

【目的】我々は、第38回の本学会で保育園 のじゅうたん、畳のダニ污染状況を報告し たが、今回、ダニアレルギーのあるアトピー 性皮膚炎や気管支喘息児が利用するその他 の公共施設でのダニ污染の実態を明らかに するため、調査を行なった。

【対象および方法】自宅の環境整備と除去 食療法中のアトピー性皮膚炎児が利用して 悪化した K 市の健康福祉センターの貼り付 けじゅうたんの部屋とR小学校の学童保育 室（1室はじゅうたん、1室は睤）、キャン プのために使用予定の天狗抗原の宿泊施設 の和室、バンガローの畳ベッド、早明浦ダ ムのコテージの和室、講演会のために使用 予定のSホテルの和室とじゅうたん敷きの ロビーを、水フィルター掃除機（タービン ノズルでほこりを吒き出して吸引するため、 普通の電気掃除機で掃除した直後でもダニ がいれば採取可能）により採取された床面 のダニ数をカウントした。

【結果】 24 時間空調されているホテルの じゅうたんからはダニは採取されなかった が、和室からは36匹/盢、健康福祉センター のじゅうたんからは 900 匹/䱉、R小学校の 学童保育室のじゅうたんからは 924 匹/盢、 畳からは189匹/畳、天狗抗原の宿泊施設の 和室からは 135 匹/畳、バンガローの冨ベッ ドからは 4860 匹/畳、早明浦ダムのコテー ジの和室からは 636 匹/畳のダニが採取さ れた。

【考察】ダニアレルギー児が利用する可能 性のある公共施設の床材としてにはじゅう たん、畳はふさわしくないと考えられた。 
O79

\section{揮発性有機化合物塗布による皮膚血管透 過性え進とその機序一ラットを用いた研 究}

○坂本龍雄 ${ }^{1)}$ 、二村昌樹 ${ }^{1)}$ 、加藤久美子 1) 木村量子 1 )、広瀬 泉 ${ }^{1)}$ 、森井志歩 1 ) 鳥居新平 2 )、森下雅史 ${ }^{3)}$ 、伊藤浩明 3 )

1)名古屋大学 大学院医学系研究科 小児科学

2) 愛知学泉大学 家政学部

3) あいち小児保健医療総合センター アレルギー 科

【背景・目的】揮発性有機化合物 (VOC) であるホルムアルデヒドは皮膚の知覚神経 C一線維を刺激し、タキキニン遊離を介して その部位に血漿漏出を引き起こす。今回、 ラットの健常皮膚に種々のVOCを塗布し、 皮膚血管透過性に及ぼす影響を検討した。

【方法】腹部を剃毛したWistarラットに、 全身麻酔下でエバンスブルーを静注した。 続いて、腹部皮膚にホルマリン $(10 \%) 、 キ$ シレン、トルエン、アセトン、n一ペプタン、 ジエチルエーテルを直径が $15 \mathrm{~mm}$ となるよ う円状に塗布し、40分後に皮膚を採取した。 皮膚に漏出したエバンスブルーをホルマミ ドで抽出し、その含有量を測定した。タキ キニンNK1 受容体拮抗剤である CP-99,994、 またはヒスタミンH1受容体拮抗薬の ketotifenを前投与し、これらのVOCによる 皮膚反応に及ぼす影響も検討した。

【結果・考察】ホルマリン、キシレン、ト ルエンは著明な皮膚血漿漏出を引き起こし たが、他のVOCではまったくこのような皮 膚反応は観察されなかった。CP-99,994は ホルマリン、キシレン、トルエンによる皮 膚血漿漏出を抑制したが、ketotifenは何ら 影響を及ぼさなかった。ホルマリン、キシ レン、トルエンは健常皮膚に浸潤し、C-線 維刺激・タキキニン遊離を介してその部位 に血漿漏出を引き起こすことが示された。
O80

\section{$\beta_{2}$ アドレナリン受容体刺激薬は腎系球 体濾過能を低下させる。}

○荻田佳織、新實 了、今泉 晃 中村明夫、柳川幸重

帝京大学 医学部 小览科

【背景と目的】 $\beta_{2}$ アドレナリン受容体 ( $\beta_{2}$ AR）刺激薬の大部分は未変化のまま腎臓よ り排泄される。このためネフロンを通過す る過程でいくつかの薬理学的効果を発揮す る。我々は、 $\beta_{2} \mathrm{AR}$ 刺激薬内服児の血清ク レアチニン值は非内服児より高值であり、 副腎ステロイド薬併用はクレアチニン值を さらに上昇させる症例を経験した。このこ とから、 $\beta_{2} A R$ 刺激薬は腎糸球体濾過能を低 下させ、ステロイドによる $\beta_{2} A R$ 過剩発現は 腎機能をさらに悪化させると考えた。今回、 この仮説を証明する目的で動物実験を実施 した。

【方法】 $\beta_{2} \mathrm{AR}$ 刺激薬を 4 週令ラット腹腔内 に投与し、24 時間後にクレアチニンクレア ランス $(\mathrm{Ccr}) 、$ 尿中 $\mathrm{Na}$ 排泄率 (FENa)、尿 中K排泄率、腎 $\beta_{2} \mathrm{AR}$ 濃度を測定した。ま た、血圧と脈拍を尾動脈より同時測定した。 ステロイドによる $\beta_{2} \mathrm{AR}$ の過剩発現モデル を $\beta_{2} \mathrm{AR}$ 遺伝子導入法により作製した。

【結果】Ccr、腎 $\beta_{2} \mathrm{AR}$ 濃度は、 $\beta_{2} \mathrm{AR}$ 刺激 薬の投与濃度に依存して低下した。また血 圧も $\beta_{2} \mathrm{AR}$ 刺激薬により降下した。 $\beta_{2} \mathrm{AR}$ 過 剩発現モデルでは、Ccr、FENaはさらに減 少した。

【考察と結論】 $\beta_{2} \mathrm{AR}$ 刺激薬は腎系球体濾過 率を減少させ、これは血圧低下が原因の 1 つと思われた。 $\beta_{2} A R$ 過剩発現の状態では腎 機能低下は著しく、Naの尿細管再吸収は方 進し、 $\beta_{2} \mathrm{AR}$ 刺激薬とステロイドの併用は腎 機能に副反応を招く可能性があると考えた。 
$\mathrm{O} 81$

\section{当院で行ったアレルギー性疾患児（主に、 鵎卵アレルギーのある児）に対するイン フルエンザワクチン接種における皮内反 応の有用性について}

○矢野一郎、稲井憲人、村川和義

屋島総合病院 小览科

昨年末、当院に通院中のアレルギー性疾 患児（主に、鶏卵アレルギーをもつ児）に 対し、事前に皮内反応を行い,インフルエン ザワクチンを接種したので報告する。皮内 反応を行った児は以下の 16 例である。

【対象】1,鵎卵成分で即時型反応を呈した 既往のある览は 5 例。2, 卵白 RAST2 以上で 完全除去をしている児は6例。3, 卵白RAST2 以上で、不完全除去をしている览は 4 例。 4 , その他 (前回接種時に腋下リンパ節腫脹) 1 例。

【結果】1の皮内反応は陰性 2 例、疑陽性 2 例、陽性 1 例であった。ワクチン接種を陰 性および疑陽性の 4 例は全量接種、陽性の 1 例は分割接種を行った。接種後 2 日で、重 大な副反応は認めなかった。2 は陰性 3 例、 疑陽性 2 例、陽性 1 例であった。陰性およ び疑陽性の 5 例は全量接種、陽性の1例は分 割接種を行った。全例、重大な副反応は認 めなかった。3 は陰性 1 例、陽性 2、強陽性 1 例であった。陰性の 1 例は全量接種、陽性 の 2 例には分割接種した。全例、重大な副 反応は認めなかった。強陽性の1例は中止 とした。4の1例は陽性で、分割投与したが 重大な副反応はなかった。

【考案】鶏卵アレルギーなどのアレルギー 性疾患児において、事前に皮内反応を用い ることによって、家族の理解を得、安全に インフルエンザワクチンを接種を行うこと ができた。
O82

\section{アレルギー児に対する予防接種実施状況 アンケート調査}

○菅井和子 1)、志賀綾子 2)、相原 雄幸 ${ }^{3)}$ 岡田賢司 4)、小倉英郎 5)、岩田 力 6 ) 横田俊平 7)

1)藤沢市民病院 小児科、2)湘南病院 小览科、 3) 横浜市立大学医学部附属市民総合医療センター 小児科、4)国立病院機構福岡病院 小児科、5)国 立高知病院 小児科、6) 東京大学 小児科、7)横浜 市立大学 小児科

アレルギー児への予防接種は皮膚テスト 施行の是非や対象者に関し，未だ現場では 混乱がある. 現状と接種医の意向を把握す るためアンケート調査を行った.

【方法】平成 15 年 12 月横浜市小巟科医会会 員全293名に宛てアンケートを行った．第 1 次アンケートでアレルギー児に対する予 防接種の実施状況や考えに関しスクリーニ ングをかけ，ワクチン皮膚テストを行って いる医師に詳細確認の 2 次アンケートを 行った。

【結果】回収率は $66.3 \% .1$ 次アンケート 有効回答166名中，アレルギー児に対し接 種前の皮膚テストを行っている医師は 28.3\%，していない医師は70.5\%。皮膚テス 卜非施行の理由は市販のテスト用試薬がな い，テスト用のワクチンの料金設定がない, 時間・手間がかかるとの理由が多かった。 卵アレルギー児に対する予防接種は, $9.6 \%$ の医師は「全例普通に接種」と答えていた 一方「専門医もしくはワクチン支援病院へ 紹介」とする医師が $32.5 \%$ あった．2次ア ンケートは 29 名より回答を得た. 皮膚テス トを行うワクチンとしては，麻疹，インフ ルエンザと回答した医師が大多数であった. 予防接種前の皮膚テス卜法は「皮内」で行 う医師が最も多く,テストはワクチン 10 倍 希釈液を用いる医師が多かった。

【結論】卵アレルギー児の取り扱いに関し 麻疹に関しても未だ危険意識をもっている 医師が多かった。今後も予防接種接種率向 上に向けさらなる対策を考慮する必要があ る. 
$\mathrm{O} 83$

\section{小児気管支喘息児における水泳教室 20 年間での有用性についての検討}

\author{
○西尾 健 1,2)、本村知華子 2)、小田嶋博 2$)$ \\ 西間三馨 2
}

1)福岡大学 医学部、2)国立病院機構 福岡病院

気管支喘息児の治療において、薬物治療 以外に水泳による運動療法は重要である。 体力の回復および向上、EIAの軽減、気道 過敏性の改善、心理面の解放などが示唆さ れ、我々も報告してきた。今回、我々は 20 年にわたる当院温水プールでの喘息児 水泳教室における安全性に関し、検討し報 告する。1984年から 2003 年の 20 年間に喘息 児水泳教室に参加した、延べ1204名の学童 を対象とした。運動前後での聴診所見、肺 機能検査と気管支拡張薬の実態について検 討した。患者背景は、男児 702 名、女児 502 名で、1・2 年生が 479 名、 3 ・4 年生が 410 名、5・6 年生が 315 名と学年が上がるにつ れて参加者数は減少していた。年間の総回 数が約 40 回で、出席率は約 70\%であった。運 動前後での聴診所見では、ほとんど変化が なく安定していた。聴診所見の改善例と悪 化例の比較では、有意に悪化例が少なかっ た。また、運動前後のFlow-volume曲線に よる肺機能による評価を検討した。PEFに おける $12.5 \%$ 以上またはFEV1.0における $10.0 \%$ 以上の変化を指標として用いた。肺 機能の改善例と悪化例の比較では、有意に 悪化例が少なかった。また、運動後の気管 支拡張薬の吸入例も少なかった。気管支 喘息の治療の変遷にも関わらず、医療ス タッフ、水泳指導スタッフの元での喘息児 水泳教室は、経年的にみても患児にとって、 安全に治療効果を挙げられると考えられた。
O84

\section{運動誘発性喘息発作を生起させる過換気 量閾値及び換気量閾値の定量化法}

○嶋田清美 1)、森村和浩 ${ }^{2)}$ 、中村有希子 1) 三好伸幸 1)、高柳友香 4)、植木 真 4) 石井絵美 1)、本村知華子 3) 手塚純一郎 3)、嶋田清隆 3)、小田嶋博 3 ) 西間三馨 ${ }^{3)}$ 、進藤宗洋 2 )

1) 福岡大学大学院 スポーツ健康科学研究科 2) 福岡大学 スポーツ科学部、3)国立病院機構 福岡病院、4)株式会社 健康科学研究所

【目的】 $\mathrm{VO}_{2}-\mathrm{VE}$ の関係において、直線的 に上昇するが、換気閾值 (VT : ほぼ血中乳 酸閾值(LT) と同值)を超える運動では、過換 気が生じるために指数関数的に呼吸数と $\mathrm{VE}$ が上昇する。過換気では、消費 $\mathrm{O}_{2}$ 量と 内因性の $\mathrm{H}_{2} \mathrm{O}$ 生成量のバランス、消費 $\mathrm{O}_{2}$ 量 と換気量に比例して増加する $\mathrm{H}_{2} \mathrm{O}$ 放出量の バランスが崩れ、消費 $\mathrm{O}_{2}$ 量に対する換気量 増加分、すなおち、 $\mathrm{H}_{2} \mathrm{O}$ 放出量増加分を生 起して、気道組織での水分損失を高進する。 これが、気道組織の浸透圧や細胞間にある ヒスタミン漏出を高め、運動誘発性喘息 （EIA）を生起する。本研究では、EIAを生 起する過換気量の存在（過換気量閾值）が あると考え、その定量化法とその妥当性に ついて検討した。

【方法】対象は気管支喘息を持つ体育大学 生 7 名。固定運動負荷による 1 . 乳酸閾值強 度を基準にした異なる運動強度で 6 分間 2.1 から EIA 陽性を示した 1つの強度を用い て運動持続時間を短縮、の $2 つ$ 視点から 検討した。

【結果】7名中 6 名がLTより高い強度でEIA を生起した。この6名において、算出した 過換気量とEIAの程度との関係で 5 名に直 線関係が認められた $(\mathrm{p}<0.1 \sim 0.01)$ 。また、 過換気量と EIA の程度の最大値に対するそ れぞれの相対值に換算し、両変数間の関係 を6名込みにして検討したところ有意な相

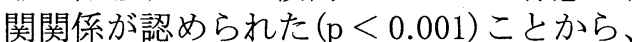
本定量化法の妥当性が考えられた。 
$\mathrm{O} 85$

\section{喘息児における定量的運動介入と健常児 における継続的自由運動介入が体力、免 疫機能に及ぼす効果の比較研究}

○石井絵美 1)、高柳友香 ${ }^{2)}$ 、松尾秀則 3$)$ 古森忠生 ${ }^{3)}$ 、本村知華子 4)、小田嶋博 ${ }^{4)}$ 西間三馨 4)、嶋田清美 1)、森村和浩 5) 進藤宗洋 5)

1)福岡大学 大学院 スポーツ健康科学研究科、2)(株) 健康科学研究所、3) 大野城市立御笠の森小学校、4)国立 病院機構 福岡病院、5)福岡大学 スポーツ科学部

【目的】喘息児を対象とした乳酸閾值 (LT) に相当する心拍数を指標とした水泳トレー ニング及び児童を対象とした始業前の 6 分 間走やボール体操と体力, 免疫機能との関 係ついて検討した.

【方法】水泳トレーニングは $\mathrm{M}$ 病院に長期 入院中の気管支喘息児 7 名 (平均值士標準 偏差, 年齢 : $13.3 \pm 1.6$ 歳, 身長 : $154.8 \pm$ $6.7 \mathrm{~cm}$, 体重: $48.1 \pm 8.4 \mathrm{~kg}$ ) で，水底ラン プペースメーカーを用い，間欠式多段階漸 増運動負荷試験を施行し, LT に相当する心 拍数（LT-HR） と泳LT-speed を同定し，3 回/週, 60 分 / 回, 7 週間, LT-HR を維持 目標とする水泳トレーニングを行った。ま た，毎朝始業前に6 分間走やボールを用い た体操を行っている M 小学校の 5, 6 年生を 対象に体力測定と唾液採取を行った。免疫 機能の指標には早朝安静時に採取した吽液 中の免疫グロブリンA（s-IgA）を用いた。

【結果】喘息児の泳 LT-speed，s-IgA 濃度 は有意に向上し，換気機能にも改善傾向が みられた。 s-IgA濃度において, Tr 前は喘 息児と $\mathrm{M}$ 小児童との間に有意な差はなかっ たが，Tr後は喘息児が有意に向上し， $\mathrm{M}$ 小 を上回った。また，泳 LT-speed変化率と $\mathrm{s}-\mathrm{IgA}$ 濃度変化量に有意な相関関係が認め られた. M小のシャトルラン, 反復横跳び, $50 \mathrm{~m}$ 走の T スコアは全国平均值より高い值 を示した。

【考察】小児においても成人と同様，継続 的な運動は体力や免疫能力を増進させるこ とを示唆し，心拍コントロールによる水泳 LTトレーニングは, 上気道のウイルス感染 やEIA生起を減少させるとともに，喘息児 の自律能力幇助手段として有効であること が示唆された。
O86

\section{EIAに及ぼす効果と治癒までの期間に関 する基礎的研究}

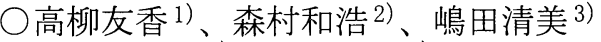 \\ 本村知華子 4)、小田嶋博 4 )、西間三馨 ${ }^{4}$ ) \\ 進藤宗洋 2)
}

1)株式会社 健康科学研究所、2)福岡大学 ス ポーツ科学部、3)福岡大学大学院 スポーツ健康 科学研究科、4)国立病院機構 福岡病院

【目的】100〜125\%LT強度のトレーニング が運動誘発性喘息に及ぼす影響について検 討した。

【方法】被検者はF病院に入院中（～2003 年まで)の気管支喘息児. 自転車エルゴメ一 タによる多段階漸増運動負荷試験は 1 分間 の安静後, 初期負荷 10watts で 4 分間w-up 行い, 1 分毎に 10watts 負荷を漸増し，心拍 数 $170 〜 180$ 拍/分を目安に終了させた.ま た，安静時及び各負荷 30 秒目から耳架採血 し, 乳酸分析器で分析し, 血中乳酸濃度と 仕事率の関係から乳酸閾值（LT）を求めた。 EIA 重症度を確認するため $175 \% \mathrm{LT}$ 強度に相 当する仕事率で 6 分間固定運動負荷試験 （EIAテスト）を行い，換気機能の測定は オートスパイロメータを用いて，安静時, 運動終了直後， $5 ， 10 ， 15 ， 20$ 分後に測定 乙, $\mathrm{FEV}_{1.0}$ 最大低下率 $\left(\mathrm{FEV}_{1.0} \%\right.$ fall $)$ を算出 した。トレーニングは100〜 125\%LT 強度, 週 $3 \sim 6$ 回, 週当たり 180 分を 6 週間行った.

【結果および考察】トレーニング後, FEV 1. $0 \%$ fall は有意に低下した。 FEV $1.0 \%$ fall 初期値 と EIA 改善量間に有意な正相関を認めた.

また，EIA改善量は重症度が軽症になるに つれて小さくな，改善量は初期段階の $\mathrm{FEV}_{1.0} \%$ fall が 10\%未満で収束すると推察さ れた. 6 週間のトレーニングを 1 期として，

トレーニング初期段階の FEV11.0\%fall 測 定することで 1 期終了時の改善量及びト レーニング 2 期目初期段階のEIA の程度 （FEV1 1.0\%fall） が予測でき，何期のトレー ニングでEIAが陰性に到達するか予測可能 な喘息治療の運動処方として用いることが できると考えられた。 
$\mathrm{O} 87$

喘息児における早朝安静時身長あたり FEV1.0值からの・自転車エルゴメーター を用いた $125 \%$ LT 強度でのトレ一ニング が運動誘発性肺換気機能低下量治癒に要 する期間・推定法の基礎的研究

○中村有希子 1）、津留史恵 ${ }^{2)}$ 、嶋田清美 1) 森村和浩 4)、本村知華子 3)、小田嶋博 3 ) 西間三馨 3 )、進藤宗洋 4)

1)福岡大学 大学院 スポーツ健康科学研究科、 2) (財) 福岡市スポーツ振興事業団、3)国立病院 機構 福岡病院、4)福岡大学 スポーツ科学部

【目的】身長当り早朝安静時 $\mathrm{FEV}_{1.0}$ 值と運 動誘発性肺換気機能低下量との関係を明ら かにし，自転車エルゴメーターを用いた 125\%LT強度での Trが及ぼす効果推定法を 検討した。

【方法】被検者は過去 7 年間にF病院に入院

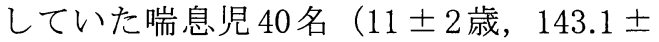
$4.4 \mathrm{~cm}, 37.3 \pm 13.8 \mathrm{~kg}$ ). 毎日早朝安静時肺 換気機能を測定. 自転車エルゴメーターで の多段階運動負荷試験を施行. 乳酸閾值

（LT）に相当する仕事率（LTw）を同定し， 175\%LT 強度で 6 分間の EIA 試験を行い負荷 前後の FEV 1.0 を測定し安静時から最も低下 した值を最大低下率（FEV $1.0 \%$ fall）とした。 また, TrはLTの100\%または125\%強度で 30 分間, 週 6 回, 6, 8 週間行った. そして 安静時と EIA 試験での肺換気機能の変化相 関関係と, 治癒に要する期間の推定法につ いて検討した。

【結果及び考察】身長当り早朝安静時 $\mathrm{FEV}_{1.0}$ と $175 \% \mathrm{LT}$ 強度での FEV $1.0 \%$ fall の間に 有意な逆相関関係が認められた（ $\mathrm{r}=0.35$, $\mathrm{p}<0.05)$. また安静時 $F E V_{1.0}$ 予測值と実 測值に $\operatorname{Tr}$ 後は $\operatorname{Tr}$ 前 $(\mathrm{r}=0.71, \mathrm{p}<0.001)$ よ りも強い相関関係（r=0.82, $\mathrm{p}<0.001)$ が 認められ, $\operatorname{Tr}$ が早朝安静時肺換気機能低下 の原因にも及んでいることを示唆した。 な お, $\operatorname{Tr}$ 前後の $\Delta$ 身長当り早朝安静時 $\mathrm{FEV}_{1.0}$

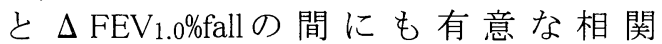
$\left(\mathrm{r}^{2}=0.34, \mathrm{r}=0.58, \mathrm{p}<0.05\right)$ が認められ, その寄与率は $34 \%$ で, 両肺換気機能低下の 病理学的共通改善因子と異なる病理学的因 子の存在が示唆された. その推定誤差と精 度 は $\operatorname{Tr}$ 前: $23.1 \pm 20.6, \operatorname{Tr}$ 後: $17.4 \pm$ 13.2 である。身長当り早朝安静時 $\mathrm{FEV}_{1.0}$ を 用いることで, EIA の程度の推測や $125 \% \mathrm{LT}$ 強度でのEIA 治瘉までの期間推測の可能性 が示唆された。
O88

\section{EIA 改善に有効なLTHR と運動様式に関 する基礎的研究}

○森村和浩 1$)$ 、高柳友香 2$)$ 、嶋田清美 3$)$ 本村知華子 4)、小田嶋博 4)、西間三馨 4 ) 進藤宗洋 1 )
1)福岡大学スポーツ科学部
2)株式会社 健康科学研究所
3) 福岡大学大学院 スポーツ健康科学研究科
4) 国立病院機構 福岡病院

【目的】喘息児を対象に自転車エルゴメー タを用いて測定した乳酸閾值 (LT) に相当 する心拍数 (eLTHR) を指標とした水泳卜 レーニングの影響について検討した.

【方法】被検者はF病院に入院し週 2 回, 半年以上院内プールで訓練をしている喘息 児 10 名（12 \pm 3 歳， $146.2 \pm 12.8 \mathrm{~cm}, 39.5$ $\pm 12.9 \mathrm{~kg})$. 自転車エルゴメータ運動負荷試 験で同定したeLTHRを目標心拍数とし，1 回 30 分以上, 週 3〜6 回, 週当たり 180 分, 6 週間の水泳トレーニングを行った. 多段 階漸増運動負荷試験を行い, 仕事率 (w) と血中乳酸濃度（La）の関係からLTに相 当する仕事率 (LTw) と eLTHR を算出した. EIA 判定は $175 \% \mathrm{LT}$ 強度で 6 分間の固定運動 負荷試験（EIAテスト）前後の FEV 1.0 の変 化值を使用した.また, 水底ペースメーカー を用い定速クロール泳で各運動時間が 1 分 間の間欠式多段階漸増最大運動負荷試験

（初期速度 $20 \mathrm{~m} / \mathrm{min}$ ，休息 1 分毎に分速 $1 \mathrm{~m}$ 漸増, ペースメーカーから遅れた時点で終 了）を施行し，La と泳スピード（sp）との 関係から LTspを算出し, sLTHRを同定した. 【結果及び考察】Tr後の単位体重当り LTw およびFEV $1.0 \%$ fall に有意な変化は認められ

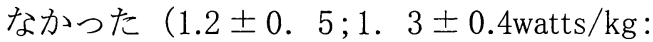
$8.1 \pm 5.3 ; 7.3 \pm 4.9 \%)$. また, $\operatorname{Tr}$ 指標で

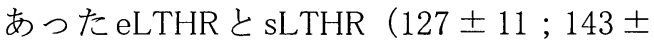
$14 \mathrm{bpm}, \mathrm{p}<0.05 ）$ に有意な差が認められ， eLTHR と sLTHRが異なることが示唆され た.しかし, Tr時のHRが sLTHRと近似し た者に関してEIAの軽快が見られたことか ら，運動様式に合致した運動強度を用いれ ばEIAの改善効果が得られる可能性が示唆 され, 各運動様式における至的運動強度を 同定し用いる必要があると考えられた. 
O89

\section{気管支喘息児の肺機能（第1 報）日常生 活の評価法} O高野 恵 ${ }^{1)}$ 、岸 幹二 11 、海上知子 2$)$
鈴木順造 3 )

1) 公立藤田総合病院 小児科
2) 小澤病院小览科
3) 福島県立医科大学 医学部 小坚科

【目的】気管支喘息治療の目的は、喘息児 の日常生活が支障なく出来ることにある。 このため喘息の治療と管理を本人と家族に 十分理解してもらうことが必要である。こ れが患者教育であり、なかでも、喘息の状 態を自己管理させることが目標となる。こ れらを客観的に把握することは容易ではな いが、その一つとして肺機能測定、喘息日 誌などがある。肺機能検査は喘息の状態を 比較的客観的に測定できるが、FVCおよび ピークフローでは重症度と関係なく良好な 值を示すことが多く、末梢気道を反映する とされているV25、V50の測定が必要となっ てくる。このたび、非発作時の喘息児の肺 機能を測定し、日常生活の状態と比較検討 したので報告する。

【対象と方法】過去 2 年間に、肺機能を 4 回以上測定できた 6 歳から 15 歳までの気管 支喘息児 10 例。日常生活の状態は運動誘発 性喘息発作の有無で判断した。

【結果】喘息児の日常生活を把握するため には喘息日誌、ピークフローなどが必要で ある。しかし、より客観的に喘息の状態を 評価するには、スパイロメーターが適して いる。今回の喘息児の肺機能測定でスパイ ロメーターは被検者により測定値が左右さ れ、測定回数が多いほど信頼度が高いこと が判明した。
O90

\section{クリティカルパスを応用した患者教育 ツールの開発（第一報）一「アトピーハ ンドブック」の作成—}
$\bigcirc$ 益子育代 1)、畠山朋美 2)、加瀬由美子 3) 明石真幸 1) 、成田雅美 1)、須田友子 1) 野村伊知郎1)、小嶋なみ子1)、松本美江子 1) 赤司賢一 4$)$ 、赤澤 晃 ${ }^{5)}$ 、大矢幸弘 ${ }^{1)}$

1) 国立成育医療センター アレルギー科、2)国立成 育医療センター 看護部 外来看護、3)国立成育医 療センター 看護部 8東病棟、4)東京慈恵医科大 学小児科、5)国立成育医療センター 総合診療部

【目的】アトピー性皮膚炎患者が病気をコ ントロールできるようにするためには、疾 患をよく理解し、セルフケアを身につける ことが必要である。そのためにクリティカ ルパスを作成し、それに基づく患者教育 ツールを開発したのでここに報告する。

【方法】（作成手続き）1）当科スタッフ内 でのコンセンサス（一貫した治療方法、使 用言語の統一)2）患者指導から患者の治療・ セルフケアにおける時期別負担・障害の分 析 3）個別指導から発生したヴァリアンス のデータ分析 (2回/月の外来カンファレン ス）4）外来診療フローチャート作成（チー 厶医療における役割分担）5）2）3）4）を 元に 1 年間を通した教育介入プログラムを 作成6）5）に対応するための患者教育ツー ル「アトピーハンドブック」の作成

【結果】「アトピーハンドブック」は、外来 診療において 1 年間で湿疹がほとんどない 状態を実現・維持できることを目標に作成 した。A．知識・セルフケアの方法 B. ケ ア実施表および定期チェックの 2 部構成と した。Aについては初回に集団教育を行い、 B 以降は実施表を連日記載していけば、3 月、6 ケ月、12 ケ月と定期的に症状 - $\mathrm{QOL} \cdot$ 治療進度、セルフケア状況についてチェッ クし、その内容に応じた専門職種からフォ ローができるようにした。このアトピーハ ンドブックの臨床における評価は第 2 報で 報告する。 
O91

\section{クリティカルパスを応用した患者教育 ツールの開発 (第二報) 一「アトピーハン ドブック」使用による教育介入の有效性一}

○皇山朋美 1)、益子育代 ${ }^{2)}$ 、緒方志穗 ${ }^{1)}$ 斎藤就美 1)、加瀬由美子 3 )、明石真幸 2 2) 成田雅美 2)、須田友子 2)、野村伊知郎 2)

小嶋なみ子2）、松本美江子2)、青田明子 2) 斎藤晆美 ${ }^{2)}$ 、二村昌樹 ${ }^{2)}$ 、赤澤 晃 4 ) 大矢幸弘 2 )

1) 国立成育医療センター 看護部 外来看護

2) 国立成育医療センター アレルギ一科

3)国立成育医療センター 看護部8 東病棟

4) 国立成育医療センター 総合診療部

【目的】当院アレルギー科外来では、初診 時に行なう集団教育を受けた患者に対し、 クリティカルパスを応用した患者教育ツー ルとしてアトピーハンドブックを用いてい る。セルフケアに対するスキルおよびそれ に伴う精神的負担や問題点について、セル フケアチェックシート（以下SCS）を使用 して把握し、それに応じた個別教育介入を 行なっている。今回は、患者教育ツールを 使用して教育介入した患者の初診時と 3 力 月後のセルフケアスキル、臨床症状、QOL スコアを評価することで、患者教育ツール の有効性について検証する。

【対象】平成 16 年 5 月以降の当科初診患者 のうち、アトピー性皮膚炎の診断を受け、 初診時に集団教育を受けた後、治療を開始 し継続している患者。

【方法】1）初診:集団教育、アトピーハン ドブック配布、QOL・臨床症状スコア チェック

2) 2、3回目: SCSチェック 後個別教育介入 3) 3 力月後:SCS、QOL. 臨床症状スコア、治療状況のチェック

4）データの分析

【結果および考察】抄録提出時点では、ま だデータ収集が完成していないため途中経 過ではあるが、患者教育ツール完成前の集 団、個人教育介入に対して、完成後は、医 師、看護師、心理士の治療に対する認識と スキルがより標準化したと思われる。その ため、患者サイドで起こる問題点が見えや すくなり、個別の教育的介入のポイントを より正確に把握することが可能になった。
O92

\section{頻回手術歴を有するラテックスアレル} ギーの 1 症例

○小林育子 1,2$) 、$ 、本修一 1)、西奈津子 1) 辻 功介 1)、宮崎倫子 1)、室英理子 1)

稲田成安 1,2$)$ 、市丸智浩 1 )、濱崎雄平 1 ) 田崎 考 3 )

1)佐賀大学 医学部 小児科

2)佐賀県立病院好生館

3)佐賀整肢学園こども発達医療センター

症例は、12 歳男児。骨形成不全の為 16 回 の頻回手術歴がある。今回、院内歯科治療 中に口腔内掻痒感が出現し、直後より咳嗽・ 呼吸困難を認めた。当科受診時、喘鳴を認 め、酸素飽和度 $94 \%$ (room air)、喘息中発 作と診断し、外来吸入・点滴加療で改善し た。詳細な問診により、数年前からゴム製 品への接触性皮膚炎の既往を認めた。また、 アレルギー検査でのラテックス CAP-RAST クラス 5 よりラテックスアレルギーと診断 した。患児に対しては、ゴム製品への接触 を避ける様に指導し、以後は無症状で経過 している。本患児のように頻回手術が必要 な場合には、予防のためにもラテックスフ リーの手術が必要であると考えられた。ま た、ハイリスクグループ（頻回導尿者、超 重症者、頻回手術歴、二分脊椎など）の 63 人についてラテックスCAP-RAST検査を施 行した。結果は、クラス 2 以上の陽性者が 6 人（約 $10 \% ）$ と高い感作率を示した。今 後は医療現場でも、ラテックスアレルギー についての詳細な問診による事前のチェッ クが重要であり、抗原量の少ない製品への 変換による予防措置が必要であると考えら れる。 
O93

\section{食物アレルギーを合併したトリクロリー ルシロップ○による薬疹の一例}

$\bigcirc$ 井上祐三朗 ${ }^{1)}$ 、内川英紀 ${ }^{1)}$ 、高谷具純 ${ }^{1,2}$, 糸洲(倫江 1,3)、冨板美奈子 1) 、鈴木修—1) 藤井克則 ${ }^{1)}$ 、高梨潤-1)、下条直樹 1 ) 河野陽一1)

1) 千葉大学 大学院 医学研究院 小児病態学

2) 千葉県こども病院、3) 千葉市立海浜病院

生後 6 ケ月発症のWest 症候群の女览。 $\mathrm{ACTH}$ 療法により点頭発作は消失し脳波所 見も改善したが、その頃より顔面や体幹の 湿疹、発熱、下痢、肝機能障害を認めるよ うになった。血清 TotallgE (884 IU/ml) の上 昇、牛乳特異 $\operatorname{IgE}(24.0 \mathrm{UA} / \mathrm{ml})$ の上昇を認め たため牛乳アレルギーを疑い、絶飲食とし たが下痢は改善せず、4 ケ月間の中心静脈 栄養を必要とした。

卵白特異 IgE (1.67 UA/ml) も陽性であっ たため、生後 11 ケ月より卵・乳製品完全除 去した離乳食および成分栄養剤による経口 栄養を開始し、以後皮膚症状・消化器症状 はみられなかった。

しかしその後、脳波検査を施行した際に トリクロリールシロップCを内服したとこ ろ、発熱、全身の紅斑、肝機能障害、血清 $\operatorname{IgE} の$ 上昇、好酸球数の上昇を認めた。卜 リクロリールシロップC、薬剤成分である トリクロホスナトリウムおよび着色料など の添加物による皮膚プリックテストおよび パッチテストを施行したところ、トリクロ リールシロップ৫およびトリクロホスナト リウムで、プリックテストは陰性でパッチ テストが陽性であり、トリクロホスナトリ ウムに対する遅延型アレルギーと考えられ た。
O94

\section{アセチルコリンに非反応の汗アレルギー の1例}

○犬尾千聡、井上和子、横内裕佳子

原 光彦、斉藤恵美子、山本康仁

都立広尾病院 小巟科

【症例】症例は 15 歳 4 ケ月。幼少時よりア トピー性皮膚炎があったが、萇麻疹が出た ことはなかった。平成 15 年 9 月 28 日、市販 品の紅茶を飲んで出かけた後、電車に駆け 込んで萇麻疹出現した。その後、体育など で軽度の運動をすると蓴麻疹が出現するよ うになった。精查のため、平成 15 年 12 月 10 日 トレッドミルにて運動負荷試験を 行った。負荷試験前には水分のみ摂取とし た。負荷後 30 分、背部を中心として発汗部 に膨疹が出現した。翌日、入浴による発汗 では、発汗部のみ膨疹が出現した。アセチ ルコリン 100umg/mlで皮内テストを施行し たが、膨疹は (衛星膨疹も含め) 生じなかっ た。自己の汗の皮内テストでは汗（10倍希 䣋) で膨疹: $11 \mathrm{~mm} * 10 \mathrm{~mm}$ 、発赤: $55 \mathrm{~mm} * 40 \mathrm{~mm}$, 汗（100 倍希釈）では膨疹 : $9 \mathrm{~mm} * 8 \mathrm{~mm}$ 、発 赤: $32 \mathrm{~mm} * 22 \mathrm{~mm}$ が出現した。最初の症状出 現時の紅茶を飲んだ後では膨疹は出現しな かった。その後、塩酸エピナスチン内服 開始した。日常生活においては、発汗時に 萇麻疹は出現しなくなった。平成 16 年 3 月 31 日に再度運動負荷試験を行った。発汗は 認めたが、萇麻疹は出現しなかった。 
O95

\section{シックハウス環境（トルエン）が喘息有 症率に与える影響について}

○蓑島宗夫 ${ }^{1)}$ 、笹川征雄 ${ }^{2)}$ 、大谷 剛 ${ }^{3)}$

1) 医療法人（社団）みのしまクリニック

2)笹川皮フ科、3)帝塚山大学 心理福祉学部

【はじめに】2002年秋に都内某小学校にお いてみられたトルエンによるシックハウス 症候群の集団発生事例を検討しアレルギー 性疾患をもつ児童は粘膜刺激症状や頭痛を 起こしやすいことを昨年本学会で発表した。 今回は同じ集団を追跡調查し、トルエン曝 露による喘息有症率への影響を検討した。

【対象および方法】 02 年 10 月、 03 年 $3 \sim 5$ 月 (春季) および 10 月実施の同小学校児童 約 400 名の保護者を対象にした問診票によ る調查および児童の健康診断の結果を解析 した。

【結果と考案】「喘息の症状がある」者は、 02 年 10 月では $1 \sim 6$ 年生中 52 名、 03 年 10 月では新 1 新 6 年生中 48 名であり、その中 の「はじめて喘息が出た」者も 02 年 2 名、 03 年 10 月 3 名と差がなかった。一方「以前 からの症状が悪化した」者は 02 年 19 名、 03 年 10 月 7 名でありトルエン曝露期間中に 有意に多かった（カイ二乗検定で $\mathrm{P}=0.01$ ）。 次に、同一個人から 3 期間にわたって回答 を得たデータをもとにパネル分析を行なっ た。被説明変数を「喘息症状」の有無とし(症 状があれば1を、なければ 0 をるる゙ミー変 数)、説明変数はトルエン濃度、春季ダミー および女性ダミーとした。分析手順で Hausman 検定を行い固定効果モデルを選択 した。結果は、「喘息症状」に対してトルエ ン濃度は正で有意 $(\mathrm{P}=0.01)$ な効果を持つこ とが分かった。以上より、教室内で曝露し ているトルエン濃度が高いほど喘息有症率 が高いことが示唆され、以前より罹患して いた喘息が増悪したためであると推察され た。
O96

572 例の化学物質過敏症の経験〜若年群 と成人群の比較検討

$\bigcirc$ 渡辺一彦

【目的】生活環境中の微量な化学物質によ る健康被害の一部は化学物質過敏症として 注目されており、その誘発症状、推定誘発 状況・物質について検討した。

【方法】病歴より症状と推定誘因状況・物 質との関わりがうかがわれ、その除去・負 荷の指導で症状の軽快・増悪が認められ、 かつそれらの再現性があり、他の誘因、他 の疾患が否定的な症例。

【結果】 91 年以降 03 年までに 572 例 (19歳 以下 297 例、20歳以上 275 例)を得た。若年 群は 00 年以降減少傾向にあり、性差が無 かった。成人群は増加傾向で、女性が男性 の3倍以上だった。誘発症状は若年群では 湿疹・皮膚炎群が主だったが、減少傾向に あり、成人群では、MCS（多種化学物質過 敏症) や眼・鼻・喉の局所刺激症状が主で、前 者は増加、後者は減少傾向であった。推定 状況・物質としては、自宅新築によるもの が両群とも減少し、成人群ではリフォーム によるものが 02 年より増加した。若年群で は園・学校によるものには変化がないが、 成人群では職場によるものが増加している。 また家具、化粧品、煙草など身近な日用品 によるものも若年群では変化がないが、成 人群では減少傾向にあった。MCS は若年群 では学校によるものが大半だったが、成人 群では自宅新築が減少し、リフォーム、職 場の関与が高まってきた。

【結論】日常診療の中で、症状の出現・増 悪と生活環境の化学物質との因果関係を十 分配慮することが求められる。 
O97

\section{受動喫煙が小児喘息の呼気中CO濃度、 呼吸機能、気道過敏性に及ぼす影響につ いて}

○五十嵐隆夫 ${ }^{1)}$ 、松野正知 ${ }^{2)}$ 、伊東道夫 ${ }^{2)}$ 足立雄一 3) 、足立陽子 3) 、尾上洋一 3 ) 村上巧啓 4$)$
O98

\section{保護者の小児アトピー性皮膚炎に対する 疾病認知と治療・ケア介入との関連}

\author{
1)いからし小児科アレルギークリニック \\ 2) 新潟県立吉田病院小児科 \\ 3) 富山医科薬科大学小児科 \\ 4) 富山赤十字病院小児科
}

【目的】家族の喫煙が小児喘息患者の呼気 中 $\mathrm{CO}$ 濃度、呼吸機能、気道過敏性に及ぼ す影響について検討した。

【対象】喫煙歴のない4から20歳（平均 12.8）の喘息患者 119 例。同居家族が全員 喫煙していない場合を非喫煙家族群（ $\mathrm{N}=$ 27、男 15、女 12）とした。同居家族の 1 人 以上が喫煙している場合を喫煙家族群（N =92、男 64、女 28）とした。

【方法】肺機能検査を行う前に呼気 $\mathrm{CO}$ 濃 度（ppm）を測定した。肺機能の項目は、 \%VC、FEV1.0/VCp（\%)、\%V50、気道過 敏性は本邦標準法によるヒスタミン吸入閾 值（Hist 值）を測定し、39,78, ㄱ，10,000 $\mu \mathrm{g} / \mathrm{ml}$ をそれぞれ $1,2, ・ ・ ・ 9$ 管とした。

【成績】非喫煙家族群と喫煙家族群の、呼 気 CO 濃度は 1.26 と 1.21 であった。\%VCは 100.7 と 102.7、FEV1.0/VCp（\%）は 90.5 と 85.8（P=0.058）、\% V50 は 103.9 と 86.1 $(\mathrm{P}<0.01) 、$ Hist 值（管）は 6.6 と 6.5 で あった。

【結論】家族に喫煙者がいると小児喘息患 者の末梢気道は非喫煙家族の患者に比較し て狭窄が強くなることが明らかとなった。

\section{○大脇淳子}

\section{杏林大学 保健学部 母子看護学・助産学}

【目的】小児アトピー性皮膚炎に対する保 護者の治療・ケア介入の実態を把握し、疾 病認知との関連を検討する。

【対象と方法】1. 対象: Y 県下、都内皮膚 科クリニック及びアトピー専門外来に通院 中の小学 4 〜学 3 年生の患者 (以下患者) の保護者 125 名 (分析対象 78名)。2. 調査 方法: 半構成面接法と自記式質問紙による アンケート調査。調查内容は患者の属性、 主治医による重症度（日本皮膚科学会の基 準:1994）、主観的重症度、かゆみの気にな る度合、治療・ケア介入の実態を調査した。 【結果と考察】1. 対象の平均年齢は 42.3 \pm 4.4 歳、患者 $12.2 \pm 1.9$ 歳、平均罹病期間 は9.5 土 3.9 年であり、主観的重症度は罹病

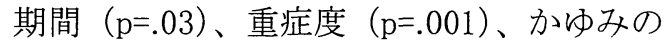
気になる度合 $(\mathrm{p}=.07)$ と関連があった。2. 治療・ケアに対する介入の実態は、全体の 約 $7 \sim 8$ 割を保護者が介入（一部介入含） していた。3. 主観的重症度は、高いほど 「内服薬の管理」（p=.06）、「衣類（寝具・ 寝衣含）の選択」（p=.06）を保護者が介入 する傾向があった。一方、皮疹・かゆみの 気になる度合は、強いほど「内服の管理」 $(p=.07) 、 「$ 衣類（寝具・寝衣含）の選択」

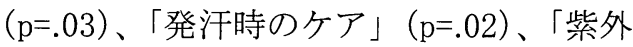
線対策」（p=.003）を患者自身の自己管理に 任せる傾向があった。治療・ケアの介入に は、保護者の皮疹・かゆみの認知が影響す る可能性がある。 
O99

\section{アトピー性皮膚炎を持つ食物アレルギー 児のQOL アンケート調査の結果}

$\bigcirc$ 寺西映子 1$)$ 、河村牧子 2)、各務美智子 3 ) 川口博史 ${ }^{4)}$ 、徳田玲子 3)、森田豊 5) 松山温子 3)、近藤康人 2)、増田 進 6 ) 山田一惠 ${ }^{7}$ 、柘植郁哉 2)、宇理須厚雄 ${ }^{3)}$

1)和田クリニック、2) 藤田保健衛生大学 小坚科 3) 藤田保健衛生大学 坂文種報徳會病院 小坚科 4) 刚谷総合病院、5)森田こどもクリニック 6)八千代病院 小児科、7)山田医院

【対象】「アレルギーを持つ子供の会」に参 加したアトピー性皮膚炎を持つ食物アレル ギー児 32 名にQOLのアンケート調査を実 施した。平均年令は 91 力月 ( $15 \sim 240$ 力月)。 男児 : 女児 $=20: 12$ 。QOLアンケート記載 者は父親 1 名、本人 1 名、残り 30 名は母親 だった。

【方法】調查項目は 1. 生活全般について 2.治療内容について 3 . 睡眠状態について 4. 学校・社会生活について 5. 環境整備・ 抗原除去について 6.スキンケアーについ て 7.食事療法について、とした。設問は 合計で 30 項目あり、満足度が高い順に 5 段 階評価し、150点満点として、QOLを点数 評価した。

【結果】合計点数が最も低かったのは 67 点、 最も高かったのは 130 点であり、平均は 101.6 点であった。項目別（最高 5 点）で見 ると、最も平均点が低かったのは「生活全 般」で2.5点、次に低かったのは「環境整 備・抗原除去」の 3 点だった。平均点が高 かったのは、「治療内容」と「睡眠状態」で、 ともに 3.7 点だった。

【考察】治療内容についてはステロイド外 用薬に対する不安はあるものの、治療内容 について納得できているという項目の平均 は4.5点と高かった。しかし、環境整備・ 抗原除去、食事療法を負担に感じている人 が多く、そのために日常生活に制限を受け ていると感じ、生活全般の満足度 $(\mathrm{QOL})$ を 低下させていると考える。今後、環境整備 や抗原除去、食事療法の重要性を十分に理 解していただくと共に、より負担の少ない 方法を考えていく必要があると認識した。
$\mathrm{O} 100$

横浜市内幼稚園児における食物アレル ギーの実態調査 : 保護者へのアンケート 調査より

○伊藤玲子 1)、石田 華 ${ }^{1)}$ 、横田俊平 ${ }^{2)}$ 相原雄幸 1 )

1) 横浜市立大学 医学部 市民総合医療センター 小児科

2) 横浜市立大学 大学院 発生成育小児医療学

【はじめに】幼稚園児における食物アレル ギーの実態と問題点を明らかにするため平 成 14 年 12 月に横浜市内の幼稚園 298 園の幼 稚園教諭にアンケート調查を実施した。同 時にその内 8 園に通園中の園児 1610 人の保 護者にも同様のアンケート調査を行った。

【結果】回答率は $71.3 \%$ 。アレルギー疾患 の罹患率は気管支喘息 $13.3 \%$ 、アトピー性 皮膚炎 $12.4 \%$ 、アレルギー性鼻炎 $9.4 \%$ 、ア レルギー性結膜炎 $3.7 \%$ 、食物アレルギー $3.3 \%$ でった。食物アレルギー罹患園児の 原因食品は鷄卵、魚介類、牛乳、そば、ピー ナッツの順であった。食物アレルギーの既 往がある園児の内幼稚園で食物除去を実施 している览は $5.9 \%$ であり、鶏卵、ピーナッ ツ、そばの順であった。医師の診断で除去 食を始めた者は $74.5 \%$ 、保護者の判断が $25.4 \%$ 、その他 $0.1 \%$ であった。現在治療中 の園児の保護者におけるアレルギー疾患に 関する認識度は、理解している $69 \%$ 、どち らでもない $21 \%$ 、わからない $10 \%$ であった。 治療への満足度では満足 $43 \%$ 、どちらでも ない $44 \%$ 、不満 $12.3 \%$ であった。満足でき ない理由では今後どうなるか不安、薬の副 作用が心配、症状がよくならないなどの意 見が目立った。

【結論】アレルギー疾患に対する理解度は 高く幼稚園で除去食が必要な園児は少な かった。また慢性疾患に対する不安感が強 く治療に対する満足度が低かった。今後も 保護者の理解度を高めていく努力が必要で あると思われた。 
0101

\section{ステロイド外用を拒絶したことにより重 症化し低蛋白血症をきたしたアトピ一性 皮膚炎の乳幼児 4 例}

○西浦可祝 1)、金田 尚 1)、三浦正義 1) 板澤寿子 2)、かせ井正春 3 )、足立雄一2) 谷内江昭宏 4 )、宮脇利男 2)

1)富山市民病院 小児科

2)富山医科薬科大学 医学部 小巟科

3) 厚生連高岡病院 小児科

4) 金沢大学 医学部 保健学科

【はじめに】アトピー性皮膚炎は皮膚疾患 であり、まず適切なスキンケアが必要であ る。しかし、ステロイド外用に対する極度 な恐怖心を持つ保護者が存在することも事 実であり、今回ステロイド使用を拒絶して いたために低蛋白血症にまで至った後に医 療機関を受診した 4 乳幼児例を経験したの で報告する。

【症例 1】4 ケ月男児。体重-2.7SD、総蛋白 $4.7 \mathrm{~g} / \mathrm{dl}$ 。保護者の家族全員が宗教に傾倒し ていた。

【症例 2】1 歳 1 ケ月男児。体重-2SD、総蛋 白 $5.4 \mathrm{~g} / \mathrm{dl}$ 。温泉を利用した民間療法と食事 制限のみを行っていた。

【症例 3】6 月月男児。体重-1.5SD、総蛋白 $5.7 \mathrm{~g} / \mathrm{dl}$ 。 好酸球性胃腸炎を合併していた。 【症例 4】5 ケ月男児。体重-2.3SD、総蛋白 $5.2 \mathrm{~g} / \mathrm{dl}$ 。助産婦の指導による食事制限と掻 破予防のための抑制帯を使用されていた。

【考案】全例とも保護者の疾患に対する知 識不足と誤解が、また一部には宗教や民間 療法がステロイド拒否を引き起こしており、 重症例では家族背景を含めた十分な情報収 集の上での対応が必要であると考えられた。
$\mathrm{O} 102$

\section{重症アトピ一性皮膚炎（AD）の入院治療 (5 年間のまとめ)}

○野間雪子 1$)$ 、藤澤隆夫 ${ }^{2)}$ 、勝又 元 $^{3)}$ 熱田 純 ${ }^{1)}$ 、井口光正 ${ }^{1)}$ 、神谷 齋 1 )

1)独立行政法人国立病院機構三重病院 小览科 2) 同臨床研究部、3) 北村小児科

【目的】近年、重症アトピー性皮膚炎が増 加している。背景として不適切な治療や民 間療法、ステロイド外用剂に対する誤った 考え方などが想定されており、正しい疾患 教育は必須である。当院では重症例につい てはガイドラインに基づいて積極的に入院 治療を行い、皮疹のコントロールとともに スキンケアや正しい外用療法について教育 を行っている。今回、最近 5 年間の症例に ついてまとめ、重症化の背景因子、治療上 の問題点、予後を検討したので報告する。

【対象】1999年より 2003 年の 5 年間に重症 $\mathrm{AD}$ の治療のため入院した患者 77 名（男 41 名、女 36 名）の入院時における背景因子、 退院後の外来治療中の問題点、退院後の予 後についてカルテより検討した。

【結果】入院に至った増悪因子として不適 切な外用法、食物アレルギー、外用剂の急 な中断、感染症 (ヘルペス、黄色ブ菌など) があげられた。また、年長児になるにつれ 家族関係、受験などのストレスの関与が考 えられた。短期または長期の入院治療によ りすべての症例で退院時は軽症となったが、 退院後に再び増悪する症例があった。その 多くは外用処置が不十分な例であった。一 方、乳児例は 1 年後に軽症でコントロール できる例が多かった。

【まとめ】症例ごとに増悪因子を適切に評 価すること、スキンケアを中心とする十分 な教育が必須である。AD は症状の評価が困 難であるが、客観的評価に基づいた治療法 選択も重要である。 
$\mathrm{O} 103$

\section{入院治療を要した1歳以下のアトピー性 皮膚炎症例の検討}

○渡辺美砂 1)、内野由美子 1)、竹内邦子 1) 藤原摩耶 1)、田中晶子 1)、柳川 進 1) 岡本則彦1)、波多野道弘 ${ }^{1)}$ 、小原 明1) 月本一郎1)
$\mathrm{O} 104$

\section{低身長を主訴に受診した $\lg E$ 高值の重症 アトピー性皮膚炎 2 症例}

○内野由美子 ${ }^{1)}$ 、渡辺美砂 ${ }^{1)}$ 、佐藤真理 ${ }^{1)}$ 小原 明 1)、佐地 勉 1)、月本一郎 1)
東邦大学 医学部 第一小児科

【はじめに】乳幼坚のアトピー性皮膚炎(以 下 $\mathrm{AD})$ では、発育発達障害を伴うことも多 く、治療だけではなく養育環境も大切な要 因となる。今回過去 10 年間に当科で入院加 療を要した 1 歳以下の $\mathrm{AD}$ 症例の検討を行 なった。

【対象と方法】1994年1月～2003年 12 月 に東邦大学大森病院小児科で入院加療を 行った AD10症例。診療記録より後方視的 に臨床症状、治療内容、経過などを検討。

【結果】発症年齢中央值 1.5 ケ月、入院時 年齢中央值 8.5 ケ月、男児 6 例、女览 4 例。 入院期間中央値 33.5 日。入院時体重増加不 良 8 例、発達遅滞 6 例、難治性下痢 5 例を認 めていた（重複あり）。入院前は 9 例でさま ざまな民間療法が試されており、ステロイ ドの外用剂を使用していたのは2例のみで、 3 例で不適切な除去食がされていた。2例が 母親の精神疾患のため養育が困難で、 $\mathrm{AD}$ 重 症化の要因と思われた。IgE中央值 $330 \mathrm{IU} / \mathrm{ml}$ 、 CAP-RAST 卵白全例陽性、食慨性抗原全例 で 2 項目以上陽性。入院後は適切な外用・ 内服療法と、適切な除去食により全例で軽 快が見られた。退院後長期観察が可能な 5 例のうち、1 例は軽快のため治療終了、2例 はコントロール良好、2例はタクロリムス 軟膏を使用中である。（残り 5 例の経過は不 明。)

【まとめ】今回の入院例では 1 例を除き、 適切な治療により外来治療が可能なケース であり、いかに適切な治療に導くことが大 切であるかを痛感した。
東邦大学 医学部 第一小児科

【症例 $1 】 4$ 歳 5 ケ月男児。 2 ケ月発症 $\mathrm{AD}$ 。 1 歳頃まで、非ステロイド外用剤（ス剂） 使用。その後悪化し、民間療法、漢方薬内 服などを試したが改善せず、4歳 1 ケ月で近 医受診。IgE26000、多抗原陽性のため、抗 アレルギー剂内服、非ス剂の使用を開始。

4 歳 4 ヶ月時に低身長の精査のため当院受 診。 $\mathrm{AD}$ と低身長、リンパ節腫脹の精査加 療目的で入院。全身状態不良。身長-2.3SD。 全身苔癬化、手背、足背腫脹 - 亀裂・熱感 あり。体幹部に膿瘍あり。腋窩および鼠径 リンパ節腫脹あり。WBC14800(Eo 22.5\%)、 CRP 0.5。IGF-1 は49 と低值だが、fT3、fT4、 TSH は正常、骨年齢 3.6 歳。

【症例 $2 】 5$ 歳 10 ヶ月男児。3 3 月発症 $\mathrm{AD}_{0}$ 。 6 ヶ月より他院で外来治療。3 歳 6 か月から 2 ケ月間、 $\mathrm{AD}$ コントロール目的で前医に入 院。その後厳格除去食、赤外線、ス剂など の治療を行っていた。4歳頃より低身長を 認めていたため、AD と低身長の精査加療目

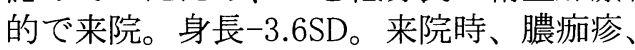
カポジ水痘様皮膚発疹を合併。IgE13000 $\mathrm{IU} / \mathrm{ml}$ 、多抗原陽性。fT3、fT4、TSH は正常。 クロニジン負荷テストでGHは正常分泌。 骨年齢 4.7 歳、IGF-1 は 110 。

【考察】ADの成長障害の原因として、1) 低栄養 2）ステロイド外用剂 3）掻痒によ る睡眠不足などが考えられているが、過去 の報告では1）が主な原因とされることが 多い。今回の症例 1 では3）が、症例 2 では 1）、3）が主な原因と推察された。皮膚所見 が改善している現在（観察期間はそれぞれ 3.3 年、 5.4 年）ともに身長の catch upが認 められる。 
O105

\section{漢方薬に依存し体重増加不良、発達遅延、 低ナトリウム血症を呈したアトピー性皮 膚炎の乳児例}

○岡松千都子、渡辺美砂、直井和之 徳山美香、月本一郎

東邦大学 医学部 第一小児科

【症例】6ヶ月男児。生後 1 か月より顔に 湿疹が出現。2 ケ月から全身に広がり皮膚 科を受診。オリーブオイル外用と漢方薬の 内服を開始。6 ケ月検診の際に体重増加不 良と発達の遅れを指摘され、精査加療目的 で紹介入院。

入院時身長 $63 \mathrm{~cm}(-1.1 \mathrm{SD})$ 体重 $5916 \mathrm{~g}$ $(-1.3 \mathrm{SD})$ 。顔面、頭部、四肢屈側を中心に 発赤・びらん・浸出液を伴った湿疹を認め た。定頚不安定、寝返り未。WBC22700/ $\mu$ 1、Eos $50.0 \% 、 \mathrm{Hb} 10.1 \mathrm{~g} / \mathrm{dl} 、 \mathrm{Na} 125 \mathrm{mM}$ 。 $\mathrm{IgE} 2700 \mathrm{IU} / \mathrm{ml}$ 、CAP RAST クラス：卵白、 牛乳 6 、小麦 4 、大豆 5 。〈BR〉入院後、漢方 薬を中止し、電解質の補正を行った。抗ア レルギー剤の内服とステロイド外用剂使用 により湿疹は徐々に軽快。卵・牛乳除去の 離乳食を開始し、体重増加が認められた。 頝定、座位も可能となり約 1 ケ月で退院。 患児に使用された漢方薬 5 剂のうち 4 剂に は乳糖が含まれており、含有率も高いもの では約 60\%(約 0.6g/日) であった。

【まとめ】漢方薬に依存し体重増加不良、 発達遅延、低ナトリウム血症を呈した AD の 6 ケ月男児例を経験した。医療機関で管 理されていたが、適切な外用療法がされて おらず、また漢方薬に含まれていた乳糖が、 強いミルクアレルギーの患児にとって抗原 となった可能性が考えられた。漢方薬と低 ナトリウム血症の因果関係は不明であるが、 漢方薬内服時にも薬剤の副作用をチェック する必要がある。
O106

\section{乳児アトピー性皮膚炎発症と在胎・出生 歴の関連についての検討}

○杉山幹雄、荒川浩一、滝沢玩己 望月博之、徳山研一、森川昭廣

群馬大学 大学院 小児生体防御学

【目的】アトピー性皮膚炎（AD）発症因子 を前方視的に検討するため、健康新生児群 の、早期新生児期および生後 1 ケ月時の皮 膚バリア機能測定を行い、これらの值と、 在胎週数、出生体重、在胎中の母体への投 薬、母体感染症との関連にについて検討し た。

【対象と方法】群馬県内にある開業産科婦 人科医院の一施設において、2002 年 7 月か ら 12 月までに出生した健康新生児 120 名。 アサヒバイオメッド社製の角質膜厚・水分 計ASA-M1を使用し、出生直後と 1 力月健診 時の、表面水分量、角質膜厚を測定した。 また、これらの值の変化と、在胎週数、出 生体重、在胎中の母体への投薬、感染症罹 患の関連について検討した。また、生後 1 歳時に、乳児期の $\mathrm{AD}$ 発症の有無につき、 郵送により親に対してアンケート調査を 行った。

【結果と考察】出生直後の日令 1 から 8 まで は、各部位の表面水分量・角質膜厚とも、 值の変動はわずかで、1 ケ月健診時には、 それぞれ著明に、増加・減少していた。表 面水分量・角質膜厚とも、出生体重による 差は認められず、在胎週数が長いほじ、表 面水分量が多くなる傾向が見られたが、有 意差は認めなかった。表面水分量・角質膜 厚とも、在胎中の母体への投薬、感染症罹 患の有無による差は認めなかった。現在、 これらの因子と $\mathrm{AD}$ 発症につき、アンケー 卜調査続行し症例数を増加し検討中である。 
O107

\section{アトピ一性皮膚炎患児における皮膚溶連 菌感染症一迅速診断の有用性}

$\bigcirc$ 植村幹二郎 1,2$)$ 、西尾久英 ${ }^{2)}$

1)うえむら小児科内科クリニック

2)神戸大学 医学部 環境応答医学

アトピー性皮膚炎（AD）患児の皮膚はA 群 $\beta$ 溶連菌（以下溶連菌）感染症が生じや すく、また増悪因子として重要である。病 像としては溶連菌性膿痂疹がよく知られて いるが、肛囲などの㱀形成部に溶連菌が皮 膚炎を起こす例も報告されている。これら の病変が表在性の場合には、迅速診断法で 診断が可能である。今回、 $\mathrm{AD}$ 患児におい て、迅速診断法で診断した溶連菌性膿痂疹 28 人、溶連菌感染による皮膚炎 4 人を経験 した。溶連菌性膿痂疹は 7 年間に 28 人を 経験し、 10 人において $2 \sim 6$ 回の再感染がみ られ、合計 53 回の感染エピソードを検討し た。2〜 5歳が多く、好発時期は 5〜9月の 高温多湿の季節であった。上下肢や顔面の 露出部分に多く見られた。皮膚炎の 4 人は $4 \cdot 5$ ケ月児で、全例血液検査で卵白 RAST 陽性であった。 1 人に 1 型糖尿病が後日判明 した。皮膚炎は仙骨下部の篞み、陰茎と陰 囊の間の皺形成部、下肢の関節のくびれ部 および前䅡部にみられ、全て㱀形成部や窪 みの部分である。膿痂疹の合併が 2 人に見 られ、膿痂疹症例と重複している。皮膚溶 連菌感染症は ADの日常診療を行っている 小児科医にとって重要な疾患で、迅速診断 を行えば簡単に診断できる。リアルタイム での対応が可能で、有用な検査である。
$\mathrm{O} 108$

\section{当院喘息患児における小児アレルギ一性 鼻炎の傾向}

$\bigcirc$ 平林靖高 1 )、亀井美智 1)、横井暁子 1) 吉田智也 1)、濱嶋直樹 1 )、岩瀬一弘 1) 福田 革 1 )、鈴木 悟 1 )、渡辺 勇 1 ) 後藤玄夫 ${ }^{1)}$ 、大島辰也 2 )

1)名古屋市立城北病院 小児科

2)名古屋市立城北病院 中央検査科

【緒言】小児気管支喘息患者は鼻炎症状を 呈することが多く、その鼻炎症状が喘息の 悪化因子になっていることも臨床上よく観 察される。そこで我々は当院におけるアレ ルギー性鼻炎（AR）の特徵を調べることで 喘息の治療の一助になるかを検討した。ま た、今回、幼少児でARを経験したのでそ の児の経過も含め報告する。<対象>2004 年 4 月 1 日から 4 月 30 日までに当院アレル ギー外来を受診した気管支喘息児の中で 2 週間以上継続するくしゃみ、水性鼻漏、鼻 閉を認めた 55 人（男 $=48 、 女=7 ） 。$

【方法】鼻炎 3 主徵を認め、かつ、血清 IgE 抗体検査と鼻汁中好酸球検査が陽性の症例 を AR と診断した。2歳未満 (A 群)、2〜 6 歳未満 (B 群)、6 歳以上 ( $\mathrm{C}$ 群) の3 群に 分け種々の検討を行った。

【結果】鼻炎症状を認めた児でAR と診断で きたのはA群 $50 \%$ 、B群 46.3\%、C 群 80\% であった。また、鼻汁中好酸球数に関して も加齢とともに増加する傾向が見られた。 通年性ARはA群 $100 \%$ 、B群は $52.6 \%$ 、C 群 $25 \%$ 、季節性 ARはA群 $0 \%$ 、B 群は $5.3 \%$ 、 C 群 $0 \%$ 、通年性+季節性 AR は A 群 $0 \%$ 、B 群は 42.1\%、C群 75\%であった。

【考察】6歳未満の喘息児では鼻炎症状を 認めた約半数がARであり、また年齢ととも に季節性 AR が増加し重症化する傾向がみ られた。今回は4月のみの検討であるため 今後は年間を通じて検討を行っていきたい。 
O109

\section{小児科医がみた喘鳴をきたす疾患と滲出 性中耳炎。}

○瀬川孝昭 ${ }^{1)}$ 、吉川秀樹 ${ }^{1)}$ 、野崎和之 ${ }^{1)}$ 秋山直枝 1)、千葉博胤 1)、山本和央 ${ }^{2)}$ 高柳博久 2)、米本友明 2)、片山 昇 ${ }^{3)}$

1)静岡県 富士市立中央病院 小览科

2)静岡県 富士市立中央病院 耳鼻咽喉科

3)片山耳鼻咽喉科

【はじめに】今回、滲出性中耳炎と喘鳴を きたす疾患 (喘息様気管支炎、気管支喘息) との関連性について統計学的な検討を行っ た。

【対象および方法】平成 9 年 1 月より平成 16 年 6 月まで当院耳鼻科と連携して診断した 中耳炎 505 症例 398 人を喘鳴をきたす疾患 と喘鳴をきたさない疾患 2 群にわけ急性中 耳炎、滲出性中耳炎の合併について検討を 行った。

【結果】急性中耳炎 255 症例、滲出性中耳 炎 264 症例であった。喘鳴をきたさない疾 患は急性中耳炎が 119 症例（69\%）滲出性中 耳炎 53 症例 (31\%)、喘鳴をきたす疾患は滲 出性中耳炎が 211 症例 (61\%) 急性中耳炎 136 症例 (39\%) と逆を示していた。滲出性中耳 炎は、喘鳴をきたす疾患（喘息様気管支炎、 気管支喘息）に多く認められた $(P<0.001)$ 。 結論 : 滲出性中耳炎は、喘鳴をきたす疾患

(喘息様気管支炎、気管支喘息) に合併が 多く認められ、病態を考えるときの示唆に なると思われた。
O110

\section{超音波エコーを用いた副鼻腔炎の診断}

○小島崇嗣 1)、小島俊巳 2)、谷内昇一郎 3$)$ 小林陽之助 ${ }^{3)}$

1)小島医院、2)こじま耳鼻咽喉科

3) 関西医大小児科

気管支喘息の増悪因子の一つに副鼻腔炎 がある。アレルギー性鼻炎の増加に伴い副 鼻腔炎を併発する小児が増加しているが、 小児科医にとって副鼻腔炎の評価は困難を 伴うことが多い。一方、副鼻腔の超音波エ コー検查は簡単でだれでも使用可能であり、 苦痛を伴うことなく繰り返し行うことがで きるために、増悪を繰り返す副鼻腔炎の診 断に適していると考えられる。そこで今回 我々は、副鼻腔炎の診断と治療経過を評価 する方法として鼻鏡による観察と同時に超 音波エコー検査を行い治療に伴うエコー像 の変化を経時的に観察することにより、そ の臨床的有用性を検討した。 
$\mathrm{O} 111$

アレルゲンの曝露とアレルギ一性鼻炎

$\bigcirc$ 三辺武幸 1)、三好 彰2)、程 雷 2$)$

殷 敏 2)、時 海波 2)、白川太郎2)

稲川俊太郎 3 )、中山明峰 3 )、稲福 繁 3 )

中村 晋4)、松井猛彦5)

1)昭和大学藤が丘病院 耳鼻咽喉科

2) 南京医科大学 国際鼻アレルギーセンター

3) 愛知医科大学 耳鼻咽喉科、4)埼玉県

5) 東京都立荏原病院小児科

あらゆる疾患は遺伝的素因に、環境的要 因が影響して発症するとされ、アレルギー 性鼻炎 (以下 $\mathrm{AR}$ )においても、この原則は通 用する。ここではアレルゲンの曝露と ARの 頻度について議論する。被験者は、〈1〉 中 国江蘇省吳江市黎里鎮の小学校 $1 \cdot 4$ 年生と 中学校 1 年生そして高校 1 年生全員と、〈2〉 中国江蘇省の南京医科大学構内の寮に在住 する大学 $1 \cdot 4$ 年生全員、さらに〈3〉 北海 道白老町の小学校 $1 \cdot 4$ 年生と中学校 1 年生 全員である。〈1〉と〈2〉においては、6・ $9 \cdot 12 \cdot 15 \cdot 18 \cdot 21$ 歳の別々の被験者のス クラッチテスト (以下 ST) 陽性率を比較し、

〈3〉については1989〜97の間に3回、6 歳時・9 歳時・12 歳時にST 受けしかもそ の間一度も医療機関を受診したことの無い

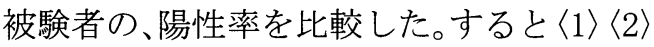

〈3〉のいずれの被験者においても、年令上 昇とともにST陽性率は有意に増加し、視 診・問診をも併せて診断された ARの頻度も、 増加していた。ARの頻度と、アレルゲンの 曝露の程度との間には、明確な相関が存在 するものと判断された。 